Prepared in cooperation with the Nevada Department of Transportation

\title{
Discharge, Sediment, and Water Chemistry in Clear Creek, Western Nevada, Water Years 2013-16
}

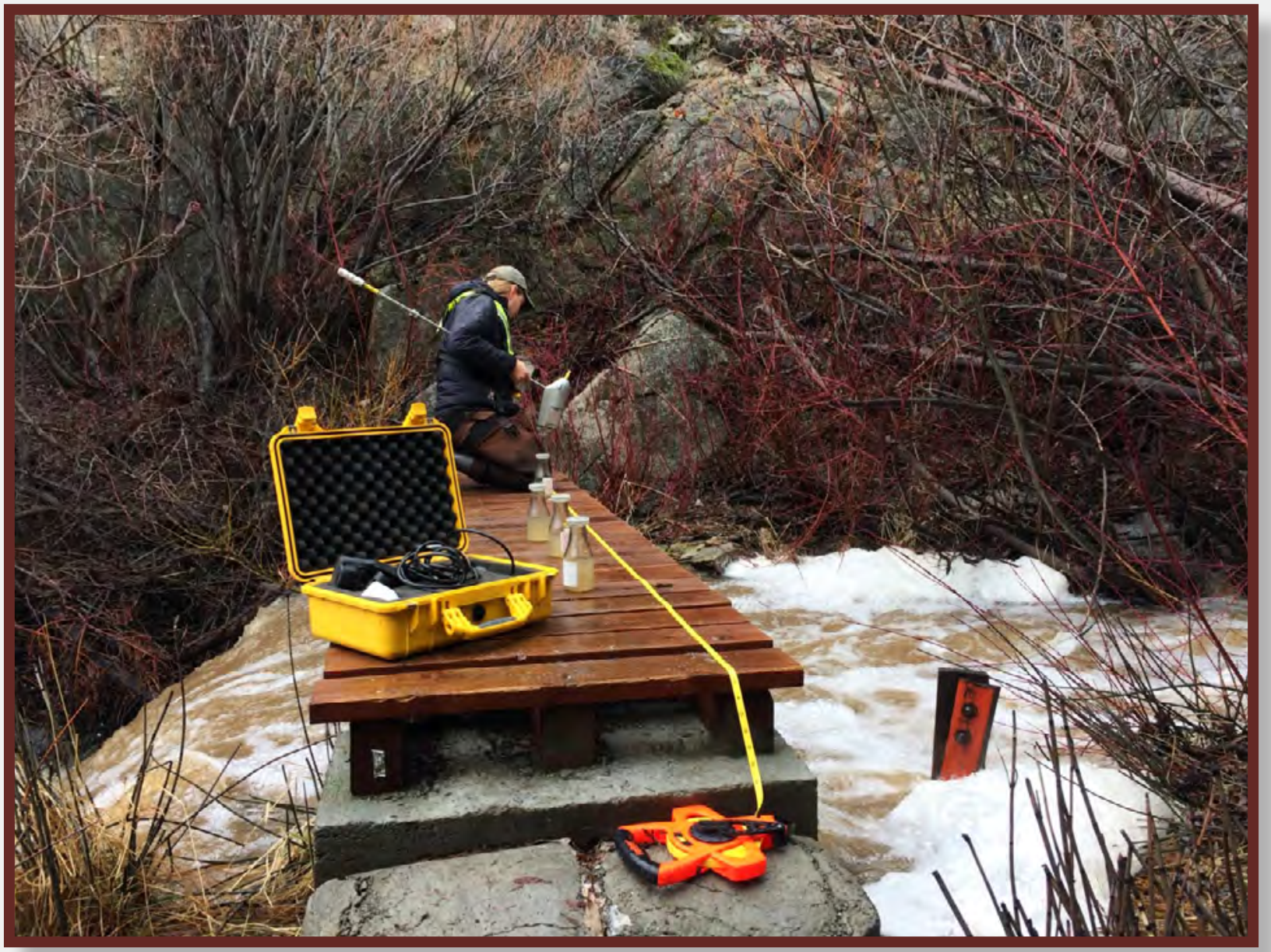

Scientific Investigations Report 2018-5050 
Cover: U.S. Geological Survey hydrologic technician Dan Riddle collecting suspendedsediment samples with a DH-48 sampler during April spring runoff conditions, Clear Creek, Western Nevada, 2017. 


\section{Discharge, Sediment, and Water Chemistry in Clear Creek, Western Nevada, Water Years 2013-16}

By Jena M. Huntington, Daniel J. Riddle, and Angela P. Paul

Prepared in cooperation with the Nevada Department of Transportation

Scientific Investigations Report 2018-5050 


\title{
U.S. Department of the Interior \\ RYAN K. ZINKE, Secretary
}

\section{U.S. Geological Survey William H. Werkheiser, Deputy Director exercising the authority of the Director}

\author{
U.S. Geological Survey, Reston, Virginia: 2018
}

For more information on the USGS - the Federal source for science about the Earth, its natural and living resources, natural hazards, and the environment-visit https://www.usgs.gov or call 1-888-ASK-USGS.

For an overview of USGS information products, including maps, imagery, and publications, visit https://store.usgs.gov.

Any use of trade, firm, or product names is for descriptive purposes only and does not imply endorsement by the U.S. Government.

Although this information product, for the most part, is in the public domain, it also may contain copyrighted materials as noted in the text. Permission to reproduce copyrighted items must be secured from the copyright owner.

Suggested citation:

Huntington, J.M., Riddle, D.J., and Paul, A.P., 2018, Discharge, sediment, and water chemistry in Clear Creek, western Nevada, water years 2013-16: U.S. Geological Survey Scientific-Investigations Report 2018-5050, 55 p., https://doi.org/10.3133/sir20185050

SSN 2328-0328 (online) 


\section{Contents}

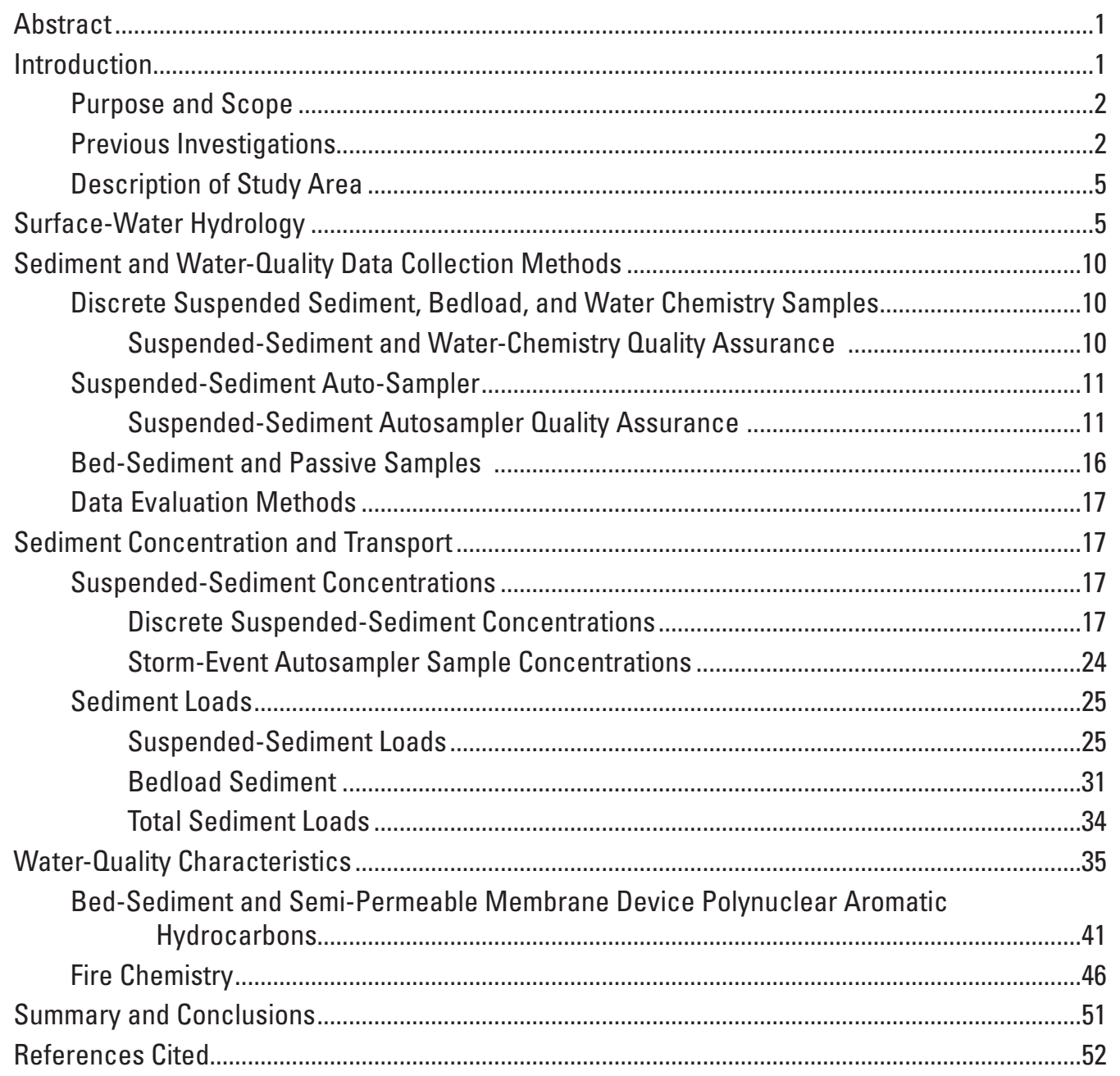




\section{Figures}

1. Map showing Clear Creek drainage basin, land ownership, and sampling sites near Carson City, Nevada.

2. Map showing Clear Creek streambed profile, locations of three sampling sites along profile locations, and extents of historical and recent wildland fires in the Clear Creek discharge basin, western Nevada, 1984-2014.

3. Map showing the locations and types of selected erosion mitigation work completed by the Nevada Department of Transportation, Clear Creek drainage basin, western Nevada, water years 2010-16

5. Graph showing mean monthly discharge for water years 1949-62 and 1990-2012 in boxplots and mean monthly discharge for water years 2013-16 in line graphs, at site 2, Clear Creek, western Nevada....

4. Graph showing mean annual discharge for periods of record at site 2, water years 1949-62 and 1990-2016

6. Graph showing fow duration at site 2, Clear Creek, western Nevada, water years 1949-2003, 2004-07, 2010-12, and 2013-16.

7. Storm hydrographs showing autosampler and discretely collected samples sent in for suspended-sediment analysis, site 2, Clear Creek, western Nevada.

8. Graphs showing relation between discrete and autosampler-collected suspended-sediment concentrations for unadjusted data and data adjusted using three flow related cross-section coefficients, Clear Creek, western Nevada

9. Graphs showing daily mean discharge and types of samples collected at site 2 for water years 2013, 2014, 2015, and 2016.

10. Graphs showing suspended-sediment concentrations at sites 1,2, and 3, Clear Creek, western Nevada, water years 2004-07, 2010-12, and 2013-16

11. Graph showing comparison of discrete and cross-section adjusted autosampler suspended-sediment concentrations, site 2, Clear Creek, western Nevada, 2004-07 and 2010-16.

12. Graph showing percentage of silt as determined using the sand-fine break analysis in suspended-sediment samples collected discretely and using the autosampler at site 2, Clear Creek, western Nevada, 2014-16.

13. Graphs showing distribution of suspended-sediment loads at sites 1,2 , and 3 on Clear Creek, western Nevada, 2004-07, 2010-12, and 2013-16, and 2004-16.

14. Graphs showing relation between suspended-sediment load and instantaneous discharge for site 1, site 2, and site 3, Clear Creek, western Nevada

15. Graphs showing suspended-sediment loads measured under specified ranges of discharge at site 1, site 2, and site 3, Clear Creek, western Nevada, water years 2004-07 and 2010-16

16. Graph showing relation between bedload and discharge at site 2, Clear Creek, western Nevada, water years 2004-07, 2010-12, and 2013-16.

17. Graph showing sediment composition and associated discharge at Clear Creek site 2 and 3,western Nevada, water years 2013-16.

18. Graph showing annual Clear Creek total sediment load and discharge for site 2 , western Nevada, 2004-07 and 2010-16.

19. Trilinear diagram depicting water type in Clear Creek, site 2, western Nevada 40 


\section{Figures}

20. Graphs showing distribution of specific conductance during period of record at all three Clear Creek sites, 2004-07 and 2010-16, and separated by study periods of 2004-07, 2010-12, and 2013-16 at site 1, site 2, and site 3 on Clear Creek, western

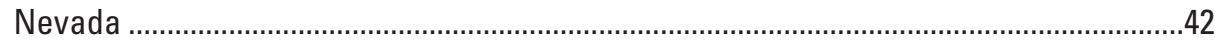

21. Graphs showing relation between discharge and specific conductance at site 1, site 2, and site 3, Clear Creek, western Nevada, water years 2004-07, 2010-12, and 2013-16.

22. Time-series of major ion concentrations at Clear Creek sampling sites, western Nevada for period of record, 2004-07 and 2010-16.

23. Time-series graphs of dissolved aluminum concentrations in Clear Creek, western Nevada at site 1, site 2, and site 3 .

24. Graphs showing normalized fluoranthrene, 1-methylphenanthrene, naphthalene, phenanthrene, and pyrene concentrations in dialysis blanks, field blanks, and environmental samples from Clear Creek, Nevada

25. Photographs showing Clear Creek fire, western Nevada, July 16-19, 2014 ...................48

26. Hydrograph of summer thunderstorm, immediately following Clear Creek fire and corresponding autosampler suspended-sediment sample collection, site 2, Clear Creek, western Nevada, July 20-21, 2014

27. Boxplots showing the relation between all suspended-sediment concentration samples collected in water year 2014-15 and the post-fire samples, site 2, Clear Creek, western Nevada

28. Line plot showing selected water chemistry at site 2, Clear Creek, western Nevada, 2014-15.

\section{Tables}

1. Description of study sites, Clear Creek, western Nevada

2. Autosampler and associated manual sample collection information, for site 2 water years 2013-16.

3. Specifications for a single semipermeable membrane device.

4. Discharge, field measurements, and discrete suspended-sediment concentrations, characteristics, and load for samples collected from Clear Creek, Western Nevada, water years 2013-16.

5. Median suspended-sediment percent finer than 0.0625 millimeter by weight for Clear Creek, Nevada, water years 2004-07, 2010-12, and 2013-16 .

6. Comparison of discrete and cross-section adjusted suspended-sediment samples at site 2 during each year of study, Clear Creek, western Nevada, 2004-16.

7. Bedload-sediment data for samples collected at sites along Clear Creek, water years 2013-16

8. Reported mean and total annual discharge, estimated annual suspended-sediment loads, annual bedload, total sediment load, and total sediment yield for site 2 ..............35

9. Selected water-quality data for samples collected at sites along Clear Creek, Nevada, water years 2013-16.

10. Frequency of selected polycyclic aromatic hydrocarbon (PAH) compound measurements in semi- permeable membrane device extracts. 


\section{Conversion Factors}

U.S. customary units to International System of Units

\begin{tabular}{|c|c|c|}
\hline Multiply & By & To obtain \\
\hline \multicolumn{3}{|c|}{ Length } \\
\hline inch (in.) & 2.54 & centimeter $(\mathrm{cm})$ \\
\hline foot $(\mathrm{ft})$ & 0.3048 & meter $(\mathrm{m})$ \\
\hline mile (mi) & 1.609 & kilometer (km) \\
\hline \multicolumn{3}{|c|}{ Area } \\
\hline acre & 4,047 & square meter $\left(\mathrm{m}^{2}\right)$ \\
\hline square mile $\left(\mathrm{mi}^{2}\right)$ & 2.590 & square kilometer $\left(\mathrm{km}^{2}\right)$ \\
\hline \multicolumn{3}{|c|}{ Volume } \\
\hline acre-foot (acre-ft) & 1,233 & cubic meter $\left(\mathrm{m}^{3}\right)$ \\
\hline acre-foot (acre-ft) & 0.001233 & cubic hectometer $\left(\mathrm{hm}^{3}\right)$ \\
\hline \multicolumn{3}{|c|}{ Flow rate } \\
\hline acre-foot per year (acre-ft/yr) & 1,233 & cubic meter per year $\left(\mathrm{m}^{3} / \mathrm{yr}\right)$ \\
\hline \multicolumn{3}{|c|}{ Mass } \\
\hline ton & 0.9072 & metric ton $(\mathrm{t})$ \\
\hline ton per day (ton/d) & 0.9072 & metric ton per day \\
\hline ton per day per square mile $\left[(\operatorname{ton} / \mathrm{d}) / \mathrm{mi}^{2}\right]$ & 0.003503 & metric ton per hectare per year \\
\hline ton per year (ton/yr) & 0.9072 & metric ton per year \\
\hline
\end{tabular}

Temperature in degrees Celsius $\left({ }^{\circ} \mathrm{C}\right)$ may be converted to degrees Fahrenheit $\left({ }^{\circ} \mathrm{F}\right)$ as follows:

$$
{ }^{\circ} \mathrm{F}=\left(1.8 \times{ }^{\circ} \mathrm{C}\right)+32
$$

Specific conductance is given in microSiemens per centimeter at 25 degrees Celsius $(\mu \mathrm{S} / \mathrm{cm}$ at $\left.25^{\circ} \mathrm{C}\right)$.

Concentrations of chemical constituents in water are given in milligrams per liter $(\mathrm{mg} / \mathrm{L})$ or micrograms per liter ( $\mu \mathrm{g} / \mathrm{L})$; polynuclear aromatic hydrocarbon (PAH) data in bottom sediment and from semipermeable membrane devices (SPMDs) are provided in micrograms per kilogram $(\mu \mathrm{g} / \mathrm{kg})$ and nanograms per membrane $(\mathrm{ng} / \mathrm{membrane})$, respectively.

\section{Datums}

Vertical coordinate information is referenced to the National Geodetic Vertical Datum of 1929 (NGVD 29).

Horizontal coordinate information is referenced to the North American Datum of 1983 (NAD 83). Altitude, as used in this report, refers to distance above the vertical datum. 


\section{Definitions}

Sediment concentration The amount of suspended solids carried by a stream in a given amount of water, expressed as mass per unit volume (milligrams per liter).

Sediment load The amount of sediment carried by a stream in a given amount of time, expressed as mass per unit time (tons per year).

Sediment transport The movement and carrying of sediment by a stream.

Sediment transport rate An instantaneous determination of the amount of sediment carried by a stream expressed as mass per unit time. For convenience in computations, it is reported in units of tons per day.

Sediment yield The amount of sediment carried by a stream in a given amount of time divided by the contributing area, expressed as mass per unit area per unit time (tons per square mile per year).

Water year The 12-month period (October 1 through September 30) designated by the calendar year in which it ends. 



\title{
Discharge, Sediment, and Water Chemistry in Clear Creek, Western Nevada, Water Years 2013-16
}

\author{
By Jena M. Huntington, Daniel J. Riddle, and Angela P. Paul
}

\section{Abstract}

Clear Creek is a small stream that drains the eastern Carson Range near Lake Tahoe, flows roughly parallel to the Highway 50 corridor, and discharges to the Carson River near Carson City, Nevada. Historical and ongoing development in the drainage basin is thought to be affecting Clear Creek and its sediment-transport characteristics. Previous studies from water years (WYs) 2004 to 2007 and from 2010 to 2012 evaluated discharge, selected water-quality parameters, and suspended-sediment concentrations, loads, and yields at three Clear Creek sampling sites. This report serves as a continuation of the data collection and analyses of the Clear Creek discharge regime and associated water-chemistry and sediment concentrations and loads during WYs 2013-16.

Total annual sediment loads ranged from 870 to 5,300 tons during WYs 2004-07, from 320 to 1,770 tons during WYs 2010-12, and from 50 to 200 tons during WYs 2013-16. Ranges in annual loads during the three study periods were not significantly different; however, total loads were greater during 2004-07 than they were during 2013-16. Annual suspended-sediment loads in WYs 2013-16 showed no significant change since WYs 2010-12 at sites 1 (U.S. Geological Survey reference site 10310485; Clear Creek above Highway 50, near Spooner Summit, Nevada) or 2 (U.S. Geological Survey streamgage 10310500; Clear Creek above Highway 50, near Spooner Summit, Nevada), but significantly lower loads at site 3 (U.S. Geological Survey site 10310518; Clear Creek at Fuji Park, at Carson City, Nevada), supporting the theory of sediment deposition between sites 2 and 3 where the stream gradient becomes more gradual. Currently, a threshold discharge of about 3.3 cubic feet per second is required to mobilize streambed sediment (bedload) from site 2 in Clear Creek. Mean daily discharge was significantly lower in 2010-12 than in 2004-07 and also significantly lower in 2013-16 than in 2010-12. During this study, lower bedload, and therefore lower total sediment load in Clear Creek was primarily due to significantly lower discharge and cannot be directly attributed to sediment mitigation work in the basin.

Water chemistry in Clear Creek shows that the general water type of the creek under base-flow conditions in autumn is a dilute calcium bicarbonate. During winter and spring, the chemistry shifts toward a slightly more sodium and chloride character. Though the chemical characteristics show seasonal change, the water chemistries examined as part of this investigation remain within ecological criteria as adopted by the Nevada Division of Environmental Protection. There was no evidence of aqueous polynuclear aromatic hydrocarbons (PAHs) present in Clear Creek water during this study. Concentrations of PAHs, as determined in one bed-sediment sample and multiple semi-permeable membrane device extracts, were either less than quantifiable limits of analysis or were found at similar concentrations as blank samples.

In July 2014, a 250-300-acre fire burned in the Clear Creek drainage basin. One day after the fire was extinguished, a thunderstorm washed sediment into the creek. A water chemistry sample collected as part of the post-fire storm event showed that the stormwater entering the creek had increased the concentrations of ammonium and organic nitrogen, phosphorus, manganese, and potassium; a similar finding of many other studies evaluating the effects of fires in small drainage basins. Subsequent chemical analyses of Clear Creek water in August 2014 (one month later) showed that these constituents had returned to pre-fire concentrations.

\section{Introduction}

In February 2004, the Nevada Division of Environmental Protection (NDEP) issued a "National Pollutant Discharge Elimination System" permit to the Nevada Department of Transportation (NDOT) for pollutants discharged into the municipal stormwater sewer system (Nevada Department of Transportation, written commun., January 2005). 
In 2005, NDOT developed the Clear Creek Storm Water Management Program to meet the permit's requirements, which were to reduce the discharge of pollutants to the stormwater drainage systems associated with highways and highway-related properties, facilities, and activities operated by NDOT in the Clear Creek drainage basin. In 2004, as part of NDOT's Storm Water Management Program, the U.S. Geological Survey (USGS) began a cooperative study with NDOT to assess the baseline conditions of general water chemistry and sediment loading in the Clear Creek drainage basin. Although NDOT had been present in the drainage basin for decades performing road management activities, these baseline conditions were to be a starting point from which to guide NDOT in planning of erosion mitigation work. Water-chemistry and suspended-sediment data were collected during water years ${ }^{1}$ (WYs) 2004-07, and results were reported by Seiler and Wood (2009). Additional information on suspended sediment and water-chemistry characteristics in Clear Creek was reported for WYs 2010-12 (Huntington and Savard, 2015). This report continues the assessment of stream discharge, sediment, and water chemistry characteristics of Clear Creek, evaluating data collected during WYs 2013-16.

The Clear Creek drainage basin lies along the eastern front of the Carson Range near Carson City, Nevada (fig. 1). The upper parts of the drainage basin border the Lake Tahoe Basin. Clear Creek is a perennial alpine stream that has its headwaters near Snow Valley Peak (altitude 9,219 ft), with three main perennial branches and several small intermittent tributaries originating from springs and seeps. Clear Creek generally flows eastward along its approximately $12 \mathrm{mi}$ length and discharges to the Carson River at an altitude of about 4,600 ft near the small community of Stewart, Nevada (fig. 1). Clear Creek is one of only two perennial streams to discharge to the Carson River in Nevada (U.S. Geological Survey, 2016).

For much of its upper reach, Clear Creek exemplifies the small, clear, cool streams of the Sierra Nevada as it winds its way through predominantly forested lands and occasional grasslands (fig. 2; Homer and others, 2015). Extreme precipitation events and human activities (for example, road construction; Stevenson, 1989) have led to channel erosion and incision in the mid-part of the drainage basin and to sediment deposition in the lower parts of the drainage basin. Several wildfires burned approximately 720 acres in the lower Clear Creek drainage basin, increasing the potential for sediment transport by removing soil litter and changing the soil's physical characteristics (fig. 2). In the mid-part of the drainage basin, potential anthropogenic influences that may be influencing urban runoff to Clear Creek and affecting its water quality and sediment load include the construction of the Highway 50 interchange (completed August 2007), a golf course irrigated with treated effluent imported from the northern Lake Tahoe Basin (completed in 2008; Brown and Caldwell and Walker \& Associates, 2009), and a residential community (under construction) (fig. 1).

In addition to urbanization, another factor potentially affecting Clear Creek water quality is the application of road salt to paved roads in the drainage basin. Clear Creek flows roughly parallel to Old Clear Creek Road (fig. 2) and, in places, is in close proximity. Salt is applied to Old Clear Creek Road and Highway 50 to provide safer winter access to private, State, Federal, and Tribal lands in the drainage basin (fig. 1). In the lower reaches of Clear Creek, the stream may be affected by urban and highway runoff, agricultural return flows, and seepage from septic-tank systems.

\section{Purpose and Scope}

In collaboration with NDOT, stream discharge, sediment, and selected water-chemistry data were collected during 2013-16 at three sites on Clear Creek (fig. 1). The objectives of this work, which built on previous monitoring studies, were to (1) obtain additional data for evaluating long-term discharge, sediment transport, and water chemistry, (2) continue the evaluation of sediment transport and changes in total sediment load over time, and (3) characterize changes in concentrations of selected water-quality constituents in Clear Creek over time, including major ions, trace metals, nutrients, dissolved oxygen, $\mathrm{pH}$, specific conductance, and alkalinity.

\section{Previous Investigations}

Several studies conducted before 2003 focused on sediment movement in the Clear Creek drainage basin. They are discussed by Seiler and Wood (2009, p. 3), while the more recent studies are briefly discussed in this section.

\footnotetext{
${ }^{1}$ A water year is the period from October 1 to September 30, designated by the year in which it ends. Water year is used almost exclusively throughout this report. In order to reduce confusion between calendar years and water years in this report, all reference to years and periods is to water years unless specifically referred to as calendar year.
} 


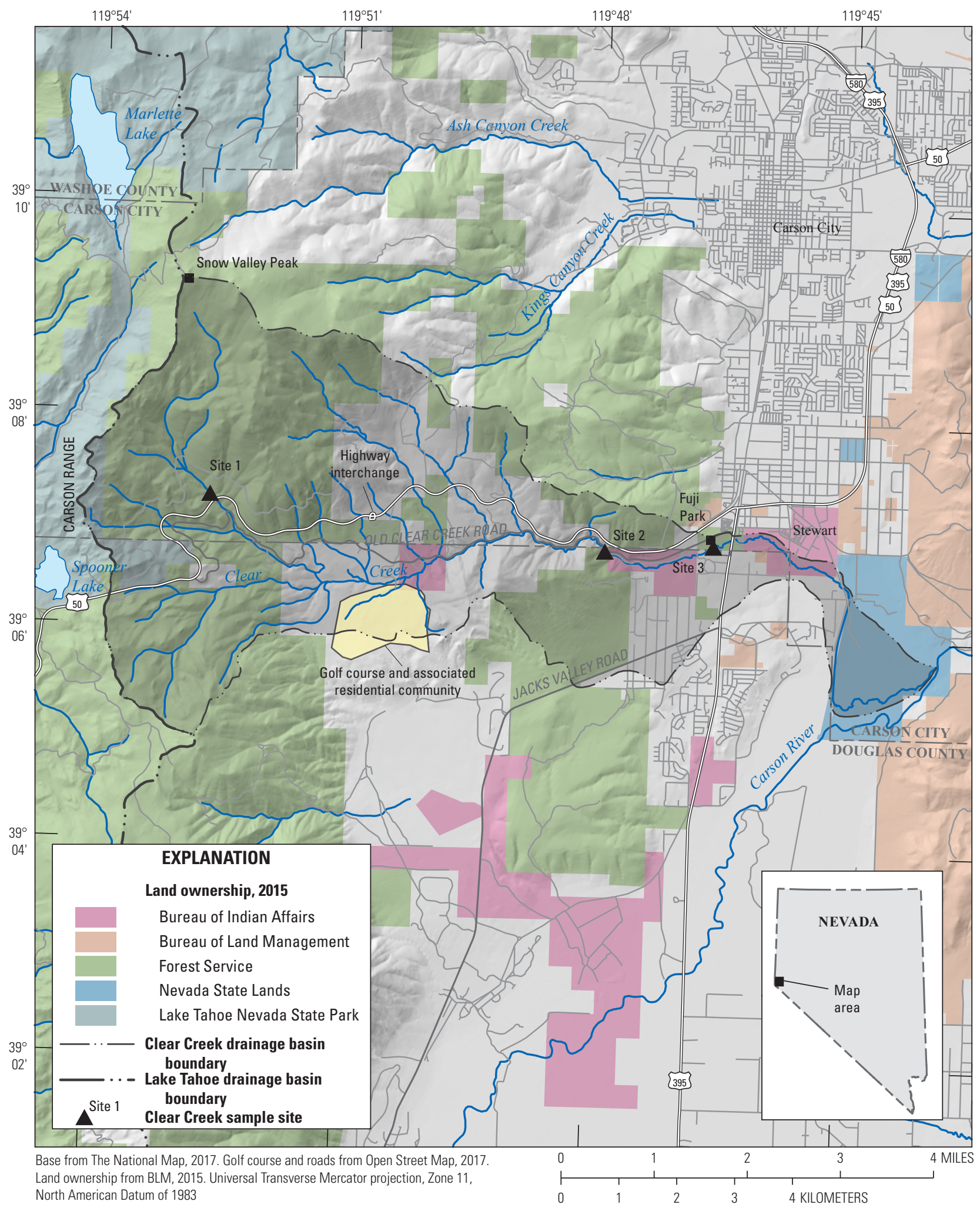

Figure 1. Clear Creek drainage basin, land ownership, and sampling sites near Carson City, Nevada. Drainage basin boundary from U.S. Geological Survey and U.S. Department of Agriculture, Natural Resources Conservation Service (2013). 


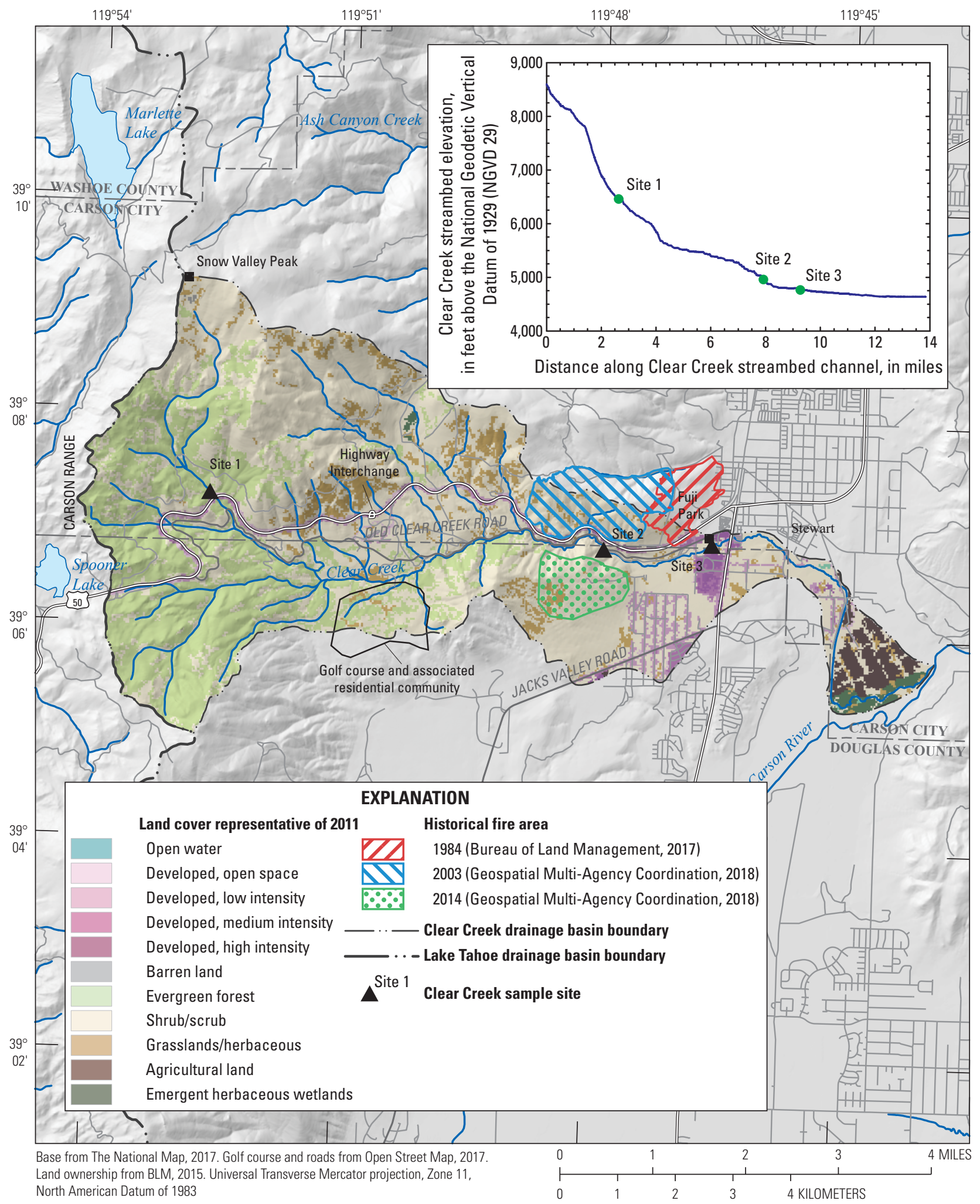

Figure 2. Clear Creek streambed profile, locations of three sampling sites along profile locations, and extents of historical and recent wildland fires in the Clear Creek discharge basin, western Nevada, 1984-2014. Drainage basin boundary from U.S. Geological Survey and U.S. Department of Agriculture, Natural Resources Conservation Service (2013). 
PBS\&J International, Inc. (2003), found that sediment transported in Clear Creek could reach the Carson River during major flood events. Seiler and Wood (2009) reported suspended-sediment concentrations ranging from 2 to $1,150 \mathrm{mg} / \mathrm{L}$ at site 3 (U.S. Geological Survey site 10310518 ; Clear Creek at Fuji Park, at Carson City, Nevada) in 2004-07, with the highest concentrations occurring during isolated storm runoff events and snowmelt runoff in the spring (site 3 indicative of suspended sediment entering the Carson River). No significant changes in these suspended-sediment concentrations were found during 2010-12 (Huntington and Savard, 2015). Suspended-sediment loads were also similar from 2004 to 2007 (baseline) and 2010-12 at all three sites (Huntington and Savard, 2015). Seiler and Wood (2009) determined that, when discharge was high enough to transport bedload, it represented between 72 and 90 percent of the total sediment load in 2004-07, which was similar to the 78 percent that Fisher (1978) reported. Huntington and Savard (2015), however, reported that bedload represented between 29 and 38 percent of total sediment load in 2010-12, which suggests a decrease in bedload between datasets. Mean daily discharge was significantly lower in 2010-12 ( $\mathrm{p}=0.026$ ) than in 2004-07 and may be the reason for the decrease in bedload that resulted in decreased total sediment load.

\section{Description of Study Area}

The Clear Creek study area covers about $19.8 \mathrm{mi}^{2}$ and drains the eastern slope of the Carson Range in the Eagle Valley hydrographic area $^{2}$ of the Carson River drainage basin (fig. 1). The altitudes in the study area range from $9,219 \mathrm{ft}$ in the headwaters near Snow Valley Peak to $4,765 \mathrm{ft}$ at Fuji Park (near site 3). After leaving Fuji Park, Clear Creek flows an additional $2.5 \mathrm{mi}$ to its confluence with the Carson River in southern Carson City (fig. 1). Detailed descriptions of study area climate, land use, vegetation cover, road network, geology, and soils were described by Seiler and Wood (2009, p. 3-12) and Huntington and Savard (2015, p. 4-5).

The study area is mostly undeveloped; however, commercial development has occurred in the eastern low altitudes area since 2003 (Huntington and Savard, 2015, fig. 2). Study area development, which has been found to alter the natural streamflow in Clear Creek, has included the road network (Stevenson, 1989), several residential areas, a golf course, and a commercial development (fig. 1). The road network, which is comprised of Highway 50, Old Clear Creek Road, and access roads, have been major contributors to erosion processes (Stevenson, 1989; Forman, 2003). Large road cuts and embankments formed steep slopes susceptible to rill erosion and landslides. Discharge from culverts associated with the road development also have caused gullies. To mitigate these effects in the Clear Creek drainage basin, NDOT, as part of the Storm Water Management Program, identified areas most susceptible to erosion and began implementing small scale mitigation efforts in April 2005; larger-scale work began in 2010 (fig. 3; Christopher Holman, Nevada Department of Transportation, written commun., May 9, 2017). Mitigation efforts in the Clear Creek drainage basin during WYs 2013-14 included abandoning drainages in NDOT right-of-ways by slurry filling (thus eliminating erosion downstream), routing discharges to more stable drainages, armoring existing channels with riprap, constructing new detention basins, and installing new down drains and culverts (Christopher Holman, Nevada Department of Transportation, written commun., February 3, 2016).

\section{Surface-Water Hydrology}

Discharge was measured at the same three sites in the Clear Creek drainage basin (figs. 1, 2, and 3; table 1) as previously measured by Seiler and Wood (2009) and Huntington and Savard (2015). Site 1 (U.S. Geological Survey reference site 10310485; Clear Creek above Highway 50, near Spooner Summit, Nevada) represents the $2.4 \mathrm{mi}^{2}$ forested and undeveloped headwaters area of Clear Creek upstream of Highway 50 (fig. 2). Site 2 (U.S. Geological Survey streamgage 10310500; Clear Creek above Highway 50 , near Spooner Summit, Nevada) represents the reach of Clear Creek 5.7 river mi downstream of site 1 and includes an additional $13.0 \mathrm{mi}^{2}$ of drainage area (15.4 $\mathrm{mi}^{2}$ cumulative) consisting of shrub/scrub community vegetation, forest, dense riparian vegetation, and low-density residential areas (fig. 2), and is the location of the continuous streamgage. Just upstream of site 2 (fig. 2), Clear Creek enters a narrow granite bedrock canyon. After exiting the narrow granite bedrock canyon at site 2, Clear Creek proceeds across an alluvial fan and then to Fuji Park and Highway 395. Site 3 (U.S. Geological Survey site 10310518; Clear Creek at Fuji Park, at Carson City, Nevada) represents the reach of Clear Creek that extends 1.4 river mi downstream of site 2 and an additional $2.7 \mathrm{mi}^{2}$ drainage area $\left(18.1 \mathrm{mi}^{2}\right.$ cumulative) consisting of similar land cover as site 2 , with the addition of some urbanized and residential areas (fig. 2). Site descriptions are provided with greater detail in Seiler and Wood (2009).

\footnotetext{
${ }^{2}$ Formal hydrographic areas in Nevada were delineated systematically by the U.S. Geological Survey and Nevada Division of Water Resources in the late 1960s for scientific and administrative purposes (Cardinalli and others, 1968; Rush, 1968). The official hydrographic-area names, numbers, and geographic boundaries continue to be used in U.S. Geological Survey information products and Nevada Division of Water Resources administrative activities.
} 


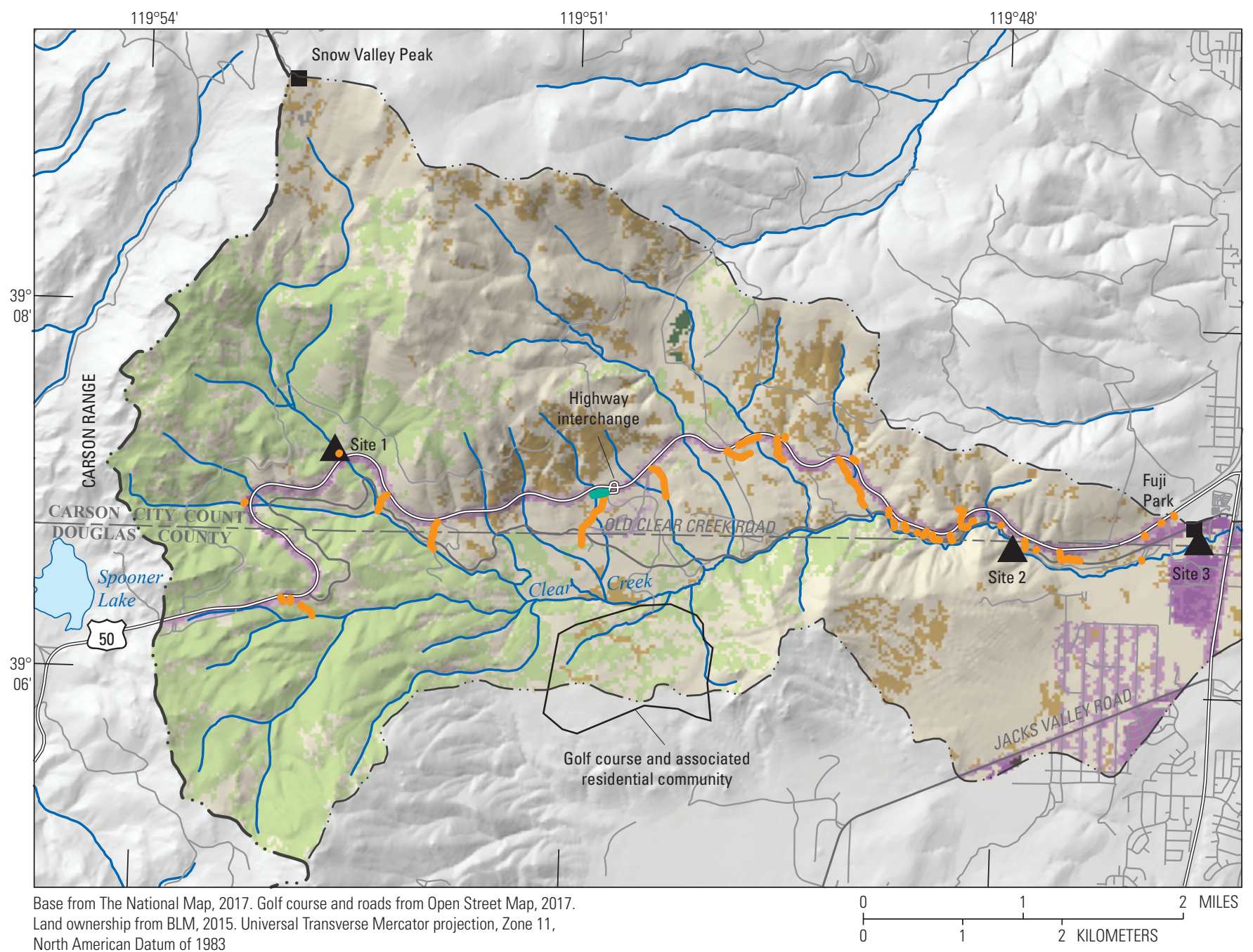

North American Datum of 1983

\section{EXPLANATION}

Land cover representative of 2011

Open water

Developed, open space

Developed, low intensity

(Nevada Department of Transportation, 2016)

Developed, medium intensity

Developed, high intensity

Barren land

Evergreen forest

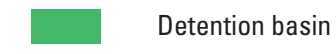

Erosion mitigation
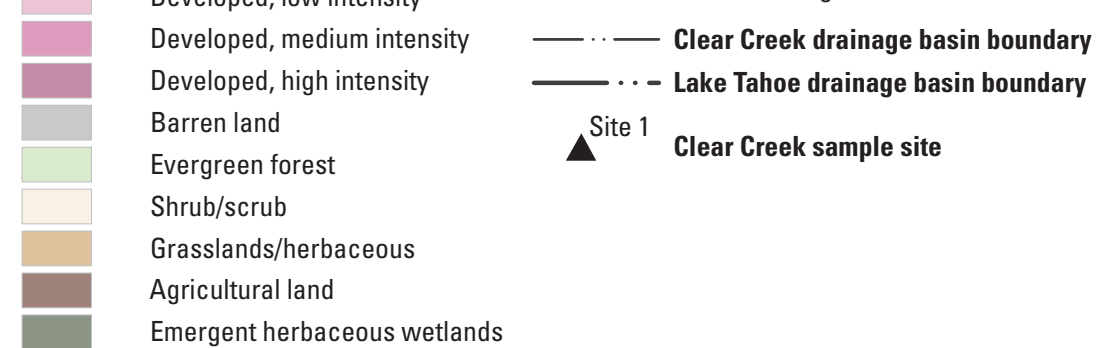

Shrub/scrub

Grasslands/herbaceous

Agricultural land

Emergent herbaceous wetlands

Figure 3. Locations and types of selected erosion mitigation work completed by the Nevada Department of Transportation (NDOT), Clear Creek drainage basin, western Nevada, water years 2010-16. Drainage basin boundary from U.S. Geological Survey and U.S. Department of Agriculture, Natural Resources Conservation Service (2013). 
Table 1. Description of study sites, Clear Creek, western Nevada.

[Site locations shown in figure 1. Latitude and Longitude are in degrees, minutes, seconds (North American Datum of 1983 [NAD 83]). Site altitude: Feet above National Geodetic Vertical Datum of 1929 (NGVD 29)]

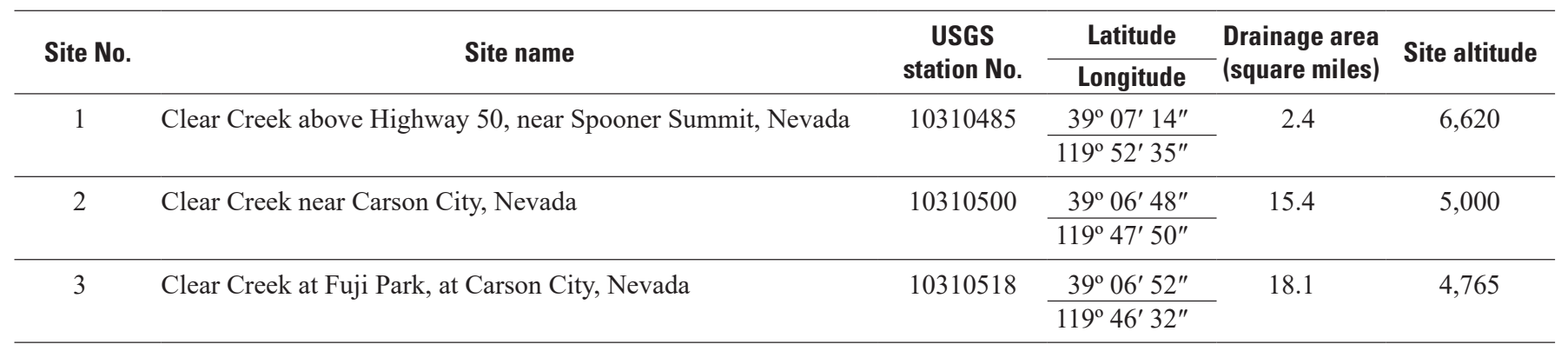

Discrete discharge measurements were made at all sites during the collection of suspended-sediment and (or) water-chemistry samples. The site 2 streamgage, Clear Creek near Carson City (altitude 5,000 ft), was a continuous recording streamgage from 1948 to 1962 and from 1989 to 2016. From 1963 to 1988, site 2 was a crest-stage gage and only peak discharges were documented. When the streamgage was operating continuously, stage was recorded at 15-minute intervals, and 15-minute discharges were computed (Rantz, 1982a, 1982b). Daily mean discharge was computed from the 15-minute discharges. During periods of ice effect ${ }^{3}$ or instrument malfunction, daily mean discharges were estimated. Since 2014, all summary discharge data for the three sites have been published in USGS WY summaries (U.S. Geological Survey, 2013, 2018).

Annual mean discharge at site 2 has varied throughout the period-of-record (1949-62 and 1990-2016; fig. 4). Previously, Glancy and Katzer (1976) reported that the 1949-62 Clear Creek annual mean discharge was $5.42 \mathrm{ft}^{3} / \mathrm{s}$. Huntington and Savard (2015) computed a long-term mean annual discharge through WY 2012 of $5.31 \mathrm{ft}^{3} / \mathrm{s}$; a similar mean annual average to that reported by Glancy and Katzer (1976). The long-term (period of record 1949-62 and 1990-2016) mean annual discharge at site 2 (fig. 1, site 2, USGS streamgage 10310500) is $5.05 \mathrm{ft}^{3} / \mathrm{s}$ (green line in fig. 4), which is lower than the long-term mean annual discharge reported by Glancy and Katzer (1976) and Huntington and Savard (2015). Figure 4 also depicts the mean annual average from 1990-2012 (all data since the data gap) of $5.24 \mathrm{ft}^{3} / \mathrm{s}$. The mean annual discharges for 2013, 2014, 2015, and 2016 at site 2 were 3.04, $2.43,2.03$, and $2.94 \mathrm{ft}^{3} / \mathrm{s}$, respectively (fig. 4), and the $2013-$ 16 mean annual discharge was $2.61 \mathrm{ft}^{3} / \mathrm{s}$. Only twice since WY 2000 has the mean annual discharge rate been greater than the long-term mean annual discharge (2006 and 2011; fig. 4). The variation in mean annual discharge is caused primarily by the annual variation of snowpack in the drainage basin; however, significant rain-on snow events can occur, such as in 1997 when the maximum mean annual discharge of $13.4 \mathrm{ft}^{3} / \mathrm{s}$ was observed.

Mean monthly discharge statistics were computed for each month over the period of record for which complete records of discharge were available. Mean monthly discharge at site 2 ranged from 0.67 to $36.3 \mathrm{ft}^{3} / \mathrm{s}$ for the period of record (March 1948-September 1962 and February 1989September 2016) and from 0.77 to $5.71 \mathrm{ft}^{3} / \mathrm{s}$ during WYs years 2013-16; fig. 5). Based on the range of elevated monthly flows observed, the maximum median mean-monthly discharge typically represented spring runoff conditions that occurred between February and May, while the minimum median mean-monthly discharge occurred when the creek was under base-flow conditions in August and September. During years of considerable snowpack, spring runoff-related discharge can make up a considerable part of the annual discharge. During 2013-16, discharge from February to May represented between 13.4 and 23 percent of the annual discharge, while for the periods of record, spring runoff-related discharge contributed between 3 and 23 percent of the annual discharge. Although the 2015 spring runoff was very small, it contributed the highest percentage of discharge to annual discharge on record because of very low-flow conditions throughout the rest of the year. Base-flow conditions during August and September for the period of record contributed between 0.5 and 4.5 percent of the annual discharge.

As a result of low precipitation conditions, all mean monthly discharges during 2013-16 were less than the median mean-monthly discharges, with the exception of November and December of WY 2013 and February of WY 2014 (fig. 5).

\footnotetext{
3"Ice effect," as described by Rantz (1982b, p. 360), is when the formation of ice in stream channels affects the stage-discharge relation by causing backwater that varies in effect with the quantity and nature of the ice, as well as with the discharge.
} 


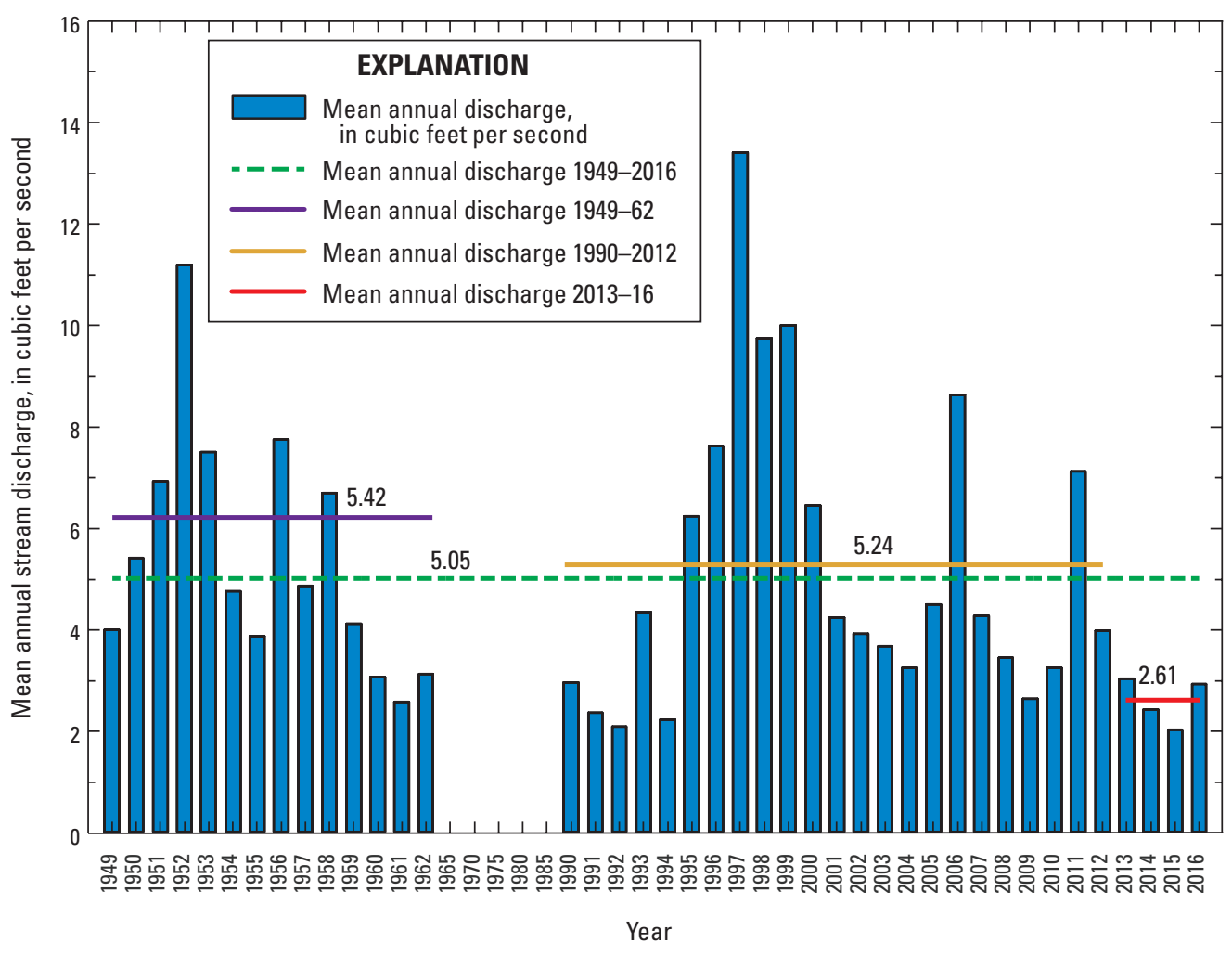

Figure 4. Mean annual discharge for periods of record at site 2 (U.S. Geological Survey streamgage 10310500; Clear Creek near Carson City, Nevada), water years 1949-62 and 1990-2016. The dashed green line represents the mean discharge for the period of record.

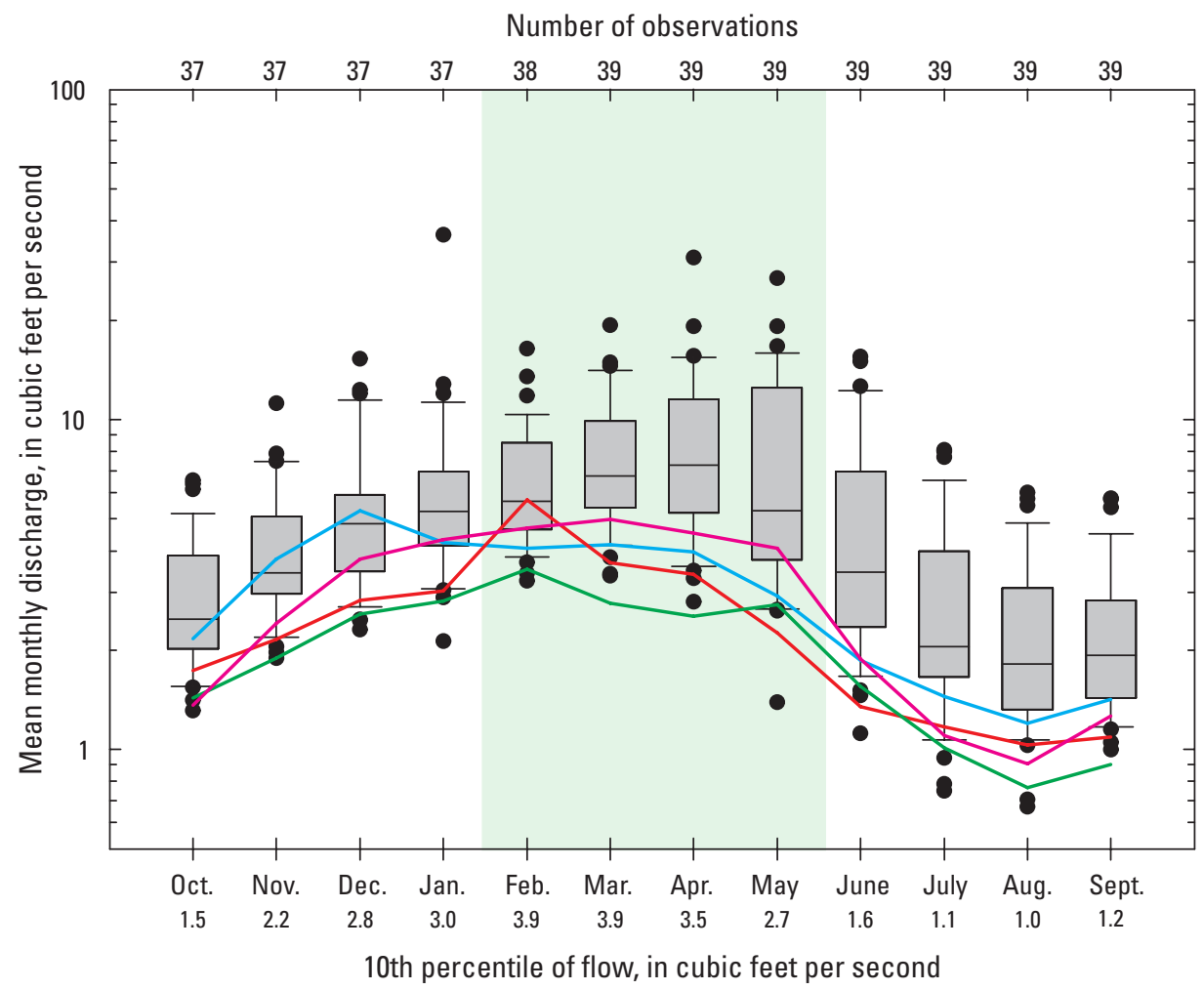

\section{EXPLANATION}

Mean monthly discharge

_ Water year 2013

Water year 2014

Water year 2015

Water year 2016

Spring runoff period

Mean monthly discharge

37 Number of values

T 90th percentile

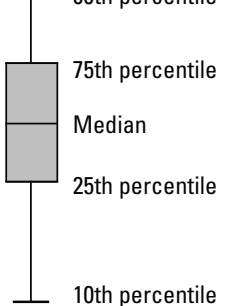

- Outlier

Figure 5. Mean monthly discharge for water years 1949-62 and 1990-2012 in boxplots and mean monthly discharge for water years 2013-16 in line graphs, at site 2, (U.S. Geological Survey streamgage 10310500; Clear Creek near Carson City, Nevada), Clear Creek, western Nevada. 
Stream discharges during WYs 2014 and 2015 were very near or less than the 10th percentile of flow for the creek (value indicated along x-axis in fig. 5), indicating particularly low precipitation conditions in the drainage basin; the only exception was for February 2014, which slightly exceeded the median discharge of $5.71 \mathrm{ft}^{3} / \mathrm{s}$ (fig. 5). The most notable mean monthly discharge data outliers represented correspond to the rain-on-snow event in January 1997, and a high-flow event that occurred during April and May 1952 (fig. 5). Notable low flows correspond to drought conditions in May 1992 and August 1992 and 1994.

Low daily discharge conditions occurred in Clear Creek during 2013-16. Generally, daily mean discharge for WYs 2013-16 plot less than the long-term period of record mean daily discharge and oftentimes plot near and sometimes less than the minimum daily discharge (fig. 5). During 2015, new minimum discharges were observed periodically during March, April, and September (fig. 5). On December 2, 2012, and February 9, 2014, Clear Creek discharge exceeded the previous maximum recorded daily discharge (fig. 5).

To characterize any changes in sediment transport dynamics in the system over time, flow-duration curves were created for stream discharge measured at site 2 for four time periods (fig. 6). The long-term discharge dataset (1949-62 and 1990-2003) was used to characterize low, moderate, and high discharge conditions for Clear Creek (fig. 6, upper x-axis). For consistency among the series of reports evaluating flow characteristics of the creek, the long-term period of flow was retained for the purposes of this evaluation and did not include flow data for WYs 2004-16. The following summarizes the flow characteristics for Clear Creek (1949-2003),

- Low discharge conditions were defined as mean daily discharges less than the 25 th percentile (about $2.3 \mathrm{ft}^{3} / \mathrm{s}$ );

- Moderate discharge conditions were defined as mean daily discharges representing flows between the 25th and 75th percentiles of mean daily discharges, respectively (about 2.3 to $6.3 \mathrm{ft}^{3} / \mathrm{s}$ ); and,

- High discharge conditions were defined as mean daily discharges exceeding the 75th percentile $\left(6.3 \mathrm{ft}^{3} / \mathrm{s}\right)$.

The actual stream-discharge values associated with each percentile of the dataset may change over time as additional discharge data become available and are incorporated into the long-term dataset. As an example, the 25th discharge percentile (about $2.3 \mathrm{ft}^{3} / \mathrm{s}$ ) has been exceeded in the creek 75 percent of the time (fig. 6).

A visual comparison of mean daily discharge for 2004-07, 2010-12, and 2013-16 to the long-term record (1949-2003) shows that, with the exception of the extreme high-discharge and low-discharge endpoints, discharge characteristics among the first study periods were similar. However, the current study exhibited notably lower mean daily discharges from the 0.1 th $\left(28 \mathrm{ft}^{3} / \mathrm{s}\right)$ to the 98 th (about $0.7 \mathrm{ft}^{3} / \mathrm{s}$ ) percentile (fig. 6), or nearly all the time. The current study period represents some of the lowest historically observed discharges for Clear Creek at any point throughout the WY.

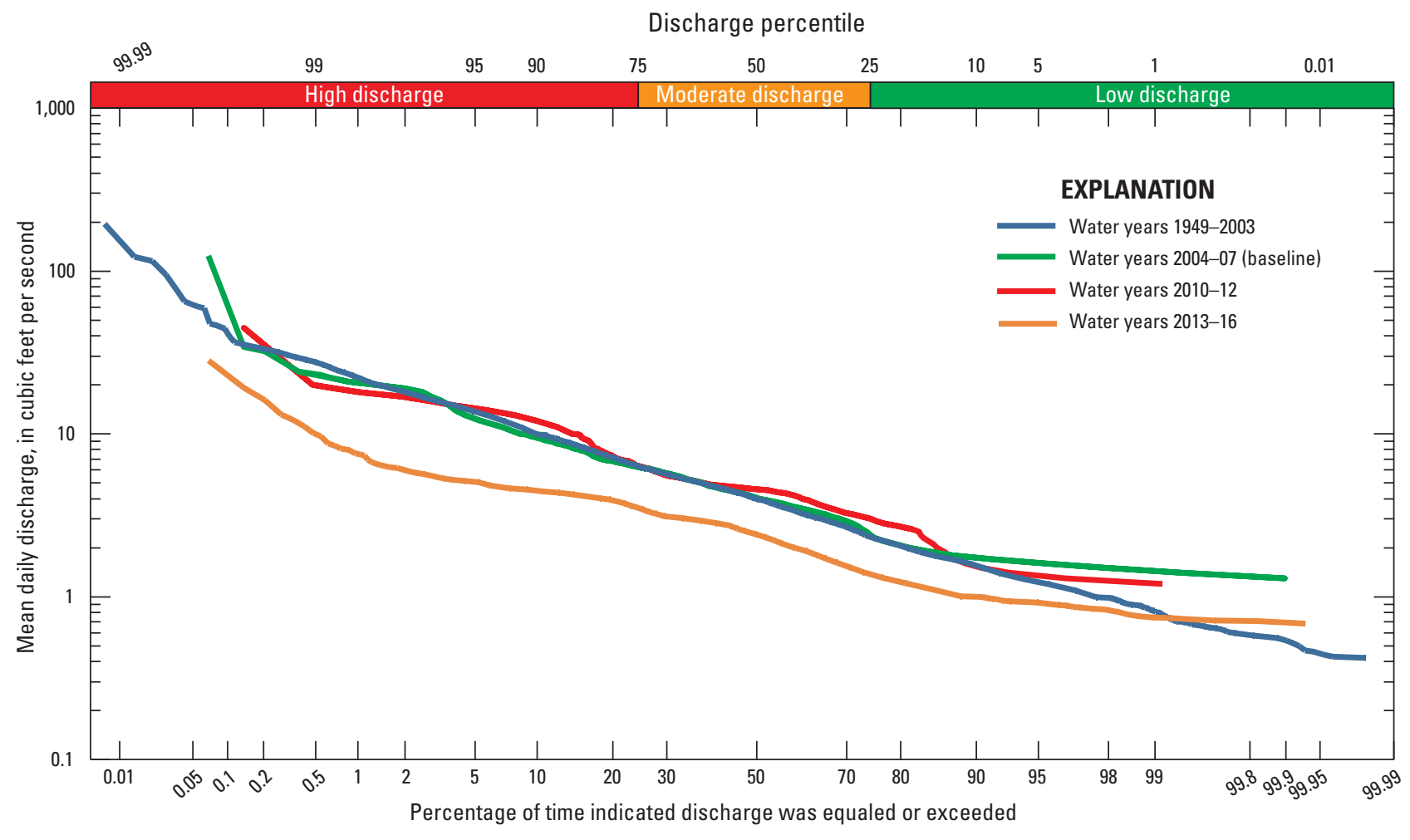

Figure 6. Flow duration at site 2 (U.S. Geological Survey streamgage 10310500; Clear Creek near Carson City, Nevada), Clear Creek, western Nevada, water years 1949-2003 (long-term dataset), 2004-07, 2010-12, and 2013-16. 


\section{Sediment and Water-Quality Data Collection Methods}

Samples were collected during 2013-16 at three Clear Creek sites to continue characterizing the sediment-transport characteristics and water quality in three distinct reaches of the creek (fig. 1). These three sites were the same sites where Seiler and Wood (2009) and Huntington and Savard (2015) collected and analyzed sediment and water-quality data during 2004-07 and 2010-12.

Samples at site 1 were collected upstream of the culvert where Highway 50 crosses Clear Creek at an altitude of 6,620 ft (figs. 1 and 2) and represents background conditions mostly free from anthropologic influences. Samples from site 2 were collected just upstream of the concrete weir at the streamgage at an altitude of 5,000 ft (figs. 1 and 2). Site 3 samples were collected just downstream of a cement culvert in a dense stand of willows in Fuji Park (altitude of 4,765 ft), adjacent to a major commercial development in Carson City (figs. 1 and 2).

\section{Discrete Suspended Sediment, Bedload, and Water Chemistry Samples}

Samples collected at each of the three Clear Creek sites were analyzed for suspended-sediment concentration and sand break, bedload and particle size distribution, and selected chemical constituent concentrations. The sand break defines the fraction of particles with sizes less than $0.0625 \mathrm{~mm}$. Particle-size distribution for bedload samples is reported in one phi intervals ranging from 0.0625 to $128 \mathrm{~mm}$. A hand-held depth integrated suspended-sediment sampler (DH-48) was used when mean depths of the sampling location were deeper than around $0.5 \mathrm{ft}$. In most cases, an equal discharge increment (EDI) methodology was used to isolate five sampling locations across the cross-section; however, during sampling events in which the stream width was sufficiently narrow (less than about $1.5 \mathrm{ft}$ ) or when the mean depth of the sampling locations were shallower than $0.5 \mathrm{ft}$, a grab sample was taken at the centroid of flow using an open mouth bottle.

Samples analyzed for bedload and particle-size distribution were collected using a Helley-Smith bedload sampler (Helley and Smith, 1971) or a BLH-84 sampler (Davis and Federal Interagency Sedimentation Project, 2005; Federal Interagency Sedimentation Project, 2013). Bedload samples were collected using equal width increment (EWI) methodology at five to seven locations across the active channel during discharges that were sufficient to mobilize bed material (determined by visual inspection). Each sample was collected by lowering a BLH- 84 bedload sampler with $0.25 \mathrm{~mm}$ size mesh bag to the streambed and resting for 30 seconds. Samples from each of the five to seven EWI locations were composited. All sediment and bedload samples were sent to the USGS sediment lab in Santa Cruz, California, for analysis. Total bedload transport was computed using methods described in Edwards and Glysson (1999, eq. 4, p. 80).

Field measurements of water temperature, specific conductance, and $\mathrm{pH}$ were made prior to each sample collection at each of the three sites following established procedures outlined in the USGS National Field Manual (Wilde, variously dated). All field measurements were obtained using a YSI Professional Series instrument. A hand-held depth integrated sampler (DH-81; Wilde and others, 2014) was used to collect samples for chemical analysis where stream depth was sufficient, as described in the first paragraph of this section. Similar to sediment collection, an EDI sampling methodology was used when stream width was greater than $1.5 \mathrm{ft}$. A plastic $8 \mathrm{~L}$ churn splitter was used to composite each vertical sample from the EDI cross sections. All water chemistry samples were sent to the National Water Quality Laboratory (NWQL) in Denver, Colorado, for analysis of major ions, trace elements, and nutrients.

\section{Suspended-Sediment and Water-Chemistry Quality Assurance}

An environmental sample is a water sample collected using appropriate methods to ensure accurate representation the local chemical conditions. Replicate samples of suspended-sediment concentration were collected for quality assurance and quality control (Horowitz and others, 1994) at Clear Creek sample sites 2 and 3 during 2013-16. Each replicate sample was collected within 15 minutes after the environmental sample and was assumed to represent similar flow and sediment conditions; however, creek characteristics can be dynamic, which commonly results in some differences between environmental and replicate samples. There was no difference between environmental and replicate suspended-sediment sample concentrations at site $2(n=1)$, indicating excellent agreement. Relative differences between environmental and replicate suspended-sediment sample concentrations at site $3(n=3)$ were 20,28 , and 4 percent in 2014, 2015, and 2016, respectively. The 2014 and 2015 replicates were collected when discharge was less than $2 \mathrm{ft}^{3} / \mathrm{s}$, while the 2016 replicate was collected when discharge was $6.4 \mathrm{ft}^{3} / \mathrm{s}$, generally indicating better agreement in replicate suspended-sediment concentrations at higher discharges. Given the degree of variability in suspended-sediment concentrations between the environmental and replicate samples from the headwaters to the downstream reach of the study area, definitive changes in suspended-sediment transport characteristics will likely be more apparent at downstream reaches in the stream than in the headwaters. 
Split replicate samples of water chemistry were collected to quantify variability associated with the processing, preservation, transport, and laboratory analyses (U.S. Geological Survey, 2006). Replicate samples were collected from each of the three sites in 2015; at site 1 in 2016 and at site 3 in 2014 and 2016 (six total study replicates). Replicate and environmental sample concentrations for constituents generally were similar with coefficients of variation ranging from 0 to 23 percent (average coefficient of variation was 5 percent).

At least one field blank was collected for quality assurance on sampling equipment and field conditions during sampling each WY to ensure that sampling equipment and conditions at the time of sampling did not contaminate samples (total, $\mathrm{n}=5$ ). Dissolved manganese $(\mathrm{Mn})$ was measured in two samples at concentrations of less than 0.4 and $0.67 \mu \mathrm{g} / \mathrm{L}$, which were between 3 and 5 percent of environmental concentrations. From 2008 to 2014, an evaluation of 1,800 blanks submitted to the USGS National Water Quality Laboratory in Denver, Colorado, from across the country showed occasional detectable concentrations of $\mathrm{Mn}(<0.4-15 \mu \mathrm{g} / \mathrm{L})$, and the detections were attributed, at least in part, to the capsule filters used during processing (U.S. Geological Survey, Office of Water Quality, written commun., 2015). Capsule filters used to process samples may have contributed to the detections $\mathrm{Mn}$ in blank samples. Other than possibly $\mathrm{Mn}$, there was nothing indicating systematic contamination of samples with any of the water chemistry constituents evaluated as part of this study.

\section{Suspended-Sediment Auto-Sampler}

A Teladyne ISCO, Inc., model 6712 autosampler was deployed from 2014 to present at site 2 to better characterize sediment transport during storm events. The sample intake line was positioned about $8 \mathrm{ft}$ upstream of the general discrete sample collection transect (with the orifice oriented perpendicular to flow) and extended about $15 \mathrm{ft}$ from the creek channel to the autosampler, resulting in a vertical lift of about $5 \mathrm{ft}$. The autosampler was interfaced with the USGS streamgage and connected directly to the stage monitor. A programming script was developed to initiate sample collection based on a threshold $0.04 \mathrm{ft} / \mathrm{h}$ increase in stage. In most cases, sampling was programmed to continue hourly after initialization until stage returned to normal following an event or until each of the twenty-four 1-L plastic bottles were filled.

Storm events triggered the autosampler to collect samples on 11 different occasions during the study period (table 2), adequately sampling most storm events that occurred. Typically, between 3 and 8 bottles per event (out of 24) were selected for sediment concentration analysis, representing different parts of the storm hydrographs (fig. 7).

\section{Suspended-Sediment Autosampler Quality Assurance}

Because streambed geometry continually changes in a dynamic alpine creek such as Clear Creek, the location and orientation of the autosampler intake can influence the particle size distribution and suspended-sediment concentration of the sample. Therefore, it is important to compare and calibrate autosampler suspended-sediment concentrations to the traditionally collected discrete suspended-sediment concentrations.

During 4 of the 11 storm events, a discrete suspended-sediment sample was also collected for the purpose of adjusting autosampler point sample concentrations to concentrations representative of the cross section (Porterfield, 1972; Edwards and Glysson, 1999). The adjusted autosampler sample concentration data are hereinafter referred to adjusted autosampler concentrations. To calibrate the autosampler, the autosampler was manually triggered to coincide with discrete sample collection on 10 occasions throughout the study period (2013-16). Paired samples were used to determine the relation between discrete and autosampler-collected sediment concentrations (table 2). The sample pair on March 6, 2014, was removed from the analysis due to the large difference in time (and therefore discharge) between the autosampler and discrete samples. Generally, under low and moderate discharge, the unadjusted autosampler suspended-sediment concentrations were greater than the concentrations collected discretely by EDI or grab sampling methods ( 33 to nearly 200 percent), regardless of whether the autosampler was triggered manually or by storm events (fig. 8A). The differences in suspended-sediment concentrations are attributed to the point sample collection of the autosampler relative to the discretely collected samples, composited to represent the entire cross-sectional area of the creek (Porterfield, 1972; Edwards and Glysson, 1999). To mitigate these differences, a cross-section coefficient was computed as the ratio of the average discrete sediment concentrations in the cross section to the single-point autosampler concentration collected at the same time (Porterfield, 1972; Edwards and Glysson, 1999). For example, the cross-section coefficient for the February 9, 2014, sample pair was computed by the ratio 263/148 (discrete concentration divided by autosampler concentration), which is equal to 1.777 . A unique coefficient was calculated for each of three discharge categories by taking the average of all individual cross-section coefficients in each discharge range: low $\left(<2.3 \mathrm{ft}^{3} / \mathrm{s}\right)$, moderate $\left(2.3 \leq\right.$ discharge $\left.\leq 6.3 \mathrm{ft}^{3} / \mathrm{s}\right)$, and high $\left(>6.3 \mathrm{ft}^{3} / \mathrm{s}\right)$. The unique coefficient in each discharge category was applied to all point autosampler suspended-sediment concentration samples, as appropriate (table 2 and fig. $8 \mathrm{~B}$ ). A single coefficient was not applied because it would over-adjust concentrations in the low and moderate discharge categories. Since Clear Creek was in drought conditions for most of the study period, particular care was given to appropriately adjust concentrations in lower flow conditions. 
Table 2. Autosampler and associated manual sample collection information for site 2 (U.S. Geological Survey streamgage 10310500; Clear Creek near Carson City, Nevada), water years 2013-16.

[Autosampler sample represents only one location in the creek, whereas the cross section represents the entire creek. A cross-section coefficient was applied to calculate corrected concentration and load for samples collected by the autosampler only. A coefficient of $0.553 \mathrm{was}$ applied to low discharge $(<2.3 \mathrm{ft} 3 / \mathrm{s})$, 0.701 to moderate discharge $\left(2.3 \leq \mathrm{Q} \leq 6.3 \mathrm{ft}^{3} / \mathrm{s}\right)$, and 1.442 to high discharge $\left(>6.3 \mathrm{ft}^{3} / \mathrm{s}\right)$. Site 2 location shown in figure 1. Date: Month-day-year. Sample time: 24-hour clock. Abbreviations: $\mathrm{ft}^{3} / \mathrm{s}$, cubic feet per second; $\mathrm{mg} / \mathrm{L}$, milligram per liter; ton/d, ton per day; -, no data available; NA, calculated value not applicable]

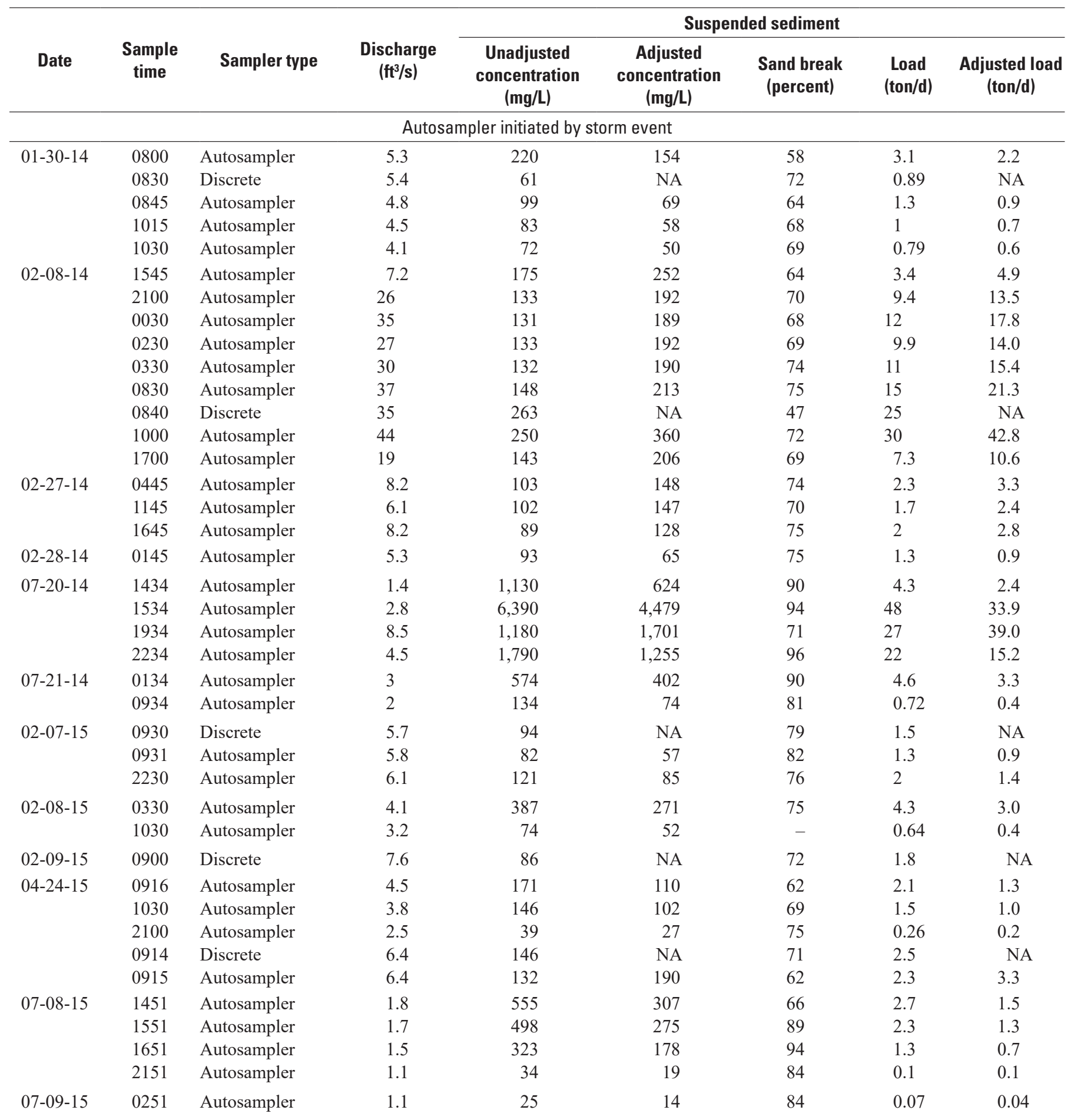


Table 2. Autosampler and associated manual sample collection information for site 2 (U.S. Geological Survey streamgage 10310500; Clear Creek near Carson City, Nevada), water years 2013-16. - Continued

\begin{tabular}{|c|c|c|c|c|c|c|c|c|}
\hline \multirow[b]{2}{*}{ Date } & \multirow[b]{2}{*}{$\begin{array}{c}\text { Sample } \\
\text { time }\end{array}$} & \multirow[b]{2}{*}{ Sampler type } & \multirow[b]{2}{*}{$\begin{array}{c}\text { Discharge } \\
\left(\mathrm{ft}^{3} / \mathbf{s}\right)\end{array}$} & \multicolumn{5}{|c|}{ Suspended sediment } \\
\hline & & & & $\begin{array}{c}\text { Unadjusted } \\
\text { concentration } \\
\text { (mg/L) }\end{array}$ & $\begin{array}{c}\text { Adjusted } \\
\text { concentration } \\
(\mathrm{mg} / \mathrm{L})\end{array}$ & $\begin{array}{c}\text { Sand break } \\
\text { (percent) }\end{array}$ & $\begin{array}{l}\text { Load } \\
\text { (ton/d) }\end{array}$ & $\begin{array}{l}\text { Adjusted load } \\
\text { (ton/d) }\end{array}$ \\
\hline \multicolumn{9}{|c|}{ Autosampler initiated by storm event-Continued } \\
\hline \multirow[t]{4}{*}{$12-21-15$} & 1315 & Autosampler & 8.5 & 275 & 396 & 72 & 6.3 & 9.1 \\
\hline & 1415 & Autosampler & 10 & 351 & 506 & 68 & 9.5 & 13.7 \\
\hline & 1515 & Autosampler & 12 & 410 & 591 & 70 & 13 & 19.1 \\
\hline & 1815 & Autosampler & 16 & 246 & 355 & 67 & 11 & 15.3 \\
\hline $12-21-15$ & 2315 & Autosampler & 13 & 90 & 130 & 65 & 3.2 & 4.6 \\
\hline \multirow[t]{2}{*}{$12-22-15$} & 0415 & Autosampler & 21 & 391 & 564 & 64 & 22 & 32.0 \\
\hline & 1115 & Autosampler & 12 & 90 & 130 & 70 & 2.9 & 4.2 \\
\hline \multirow[t]{2}{*}{$01-22-16$} & 2102 & Autosampler & 6.9 & 288 & 415 & 57 & 5.4 & 7.7 \\
\hline & 2302 & Autosampler & 7.9 & 138 & 199 & 71 & 2.9 & 4.2 \\
\hline $01-23-16$ & 0402 & Autosampler & 6.7 & 63 & 91 & 60 & 1.1 & 1.6 \\
\hline 03-04-16 & 2342 & Autosampler & 5.8 & 105 & 74 & 62 & 1.6 & 1.2 \\
\hline \multirow[t]{2}{*}{$03-05-16$} & 0342 & Autosampler & 7.7 & 161 & 232 & 58 & 3.3 & 4.8 \\
\hline & 0542 & Autosampler & 6.9 & 58 & 84 & 72 & 1.1 & 1.6 \\
\hline \multirow[t]{3}{*}{$04-22-16$} & 1738 & Autosampler & 6.8 & 557 & 803 & 65 & 10 & 14.7 \\
\hline & 1838 & Autosampler & 7.7 & 296 & 427 & 60 & 6.2 & 8.9 \\
\hline & 2338 & Autosampler & 6.2 & 47 & 33 & 78 & 0.79 & 0.55 \\
\hline \multicolumn{9}{|c|}{ Autosampler initiated by field personnel } \\
\hline \multirow[t]{2}{*}{${ }^{1} 03-06-14$} & 0130 & Autosampler & 6.7 & 128 & 185 & 81 & 2.3 & 3.3 \\
\hline & 1030 & Discrete & 7.2 & 85 & NA & 87 & 1.7 & NA \\
\hline \multirow[t]{2}{*}{$03-19-14$} & 1415 & Discrete & 3.4 & 5 & NA & - & 0.05 & NA \\
\hline & 1416 & Autosampler & 3 & 13 & 9 & - & 0.11 & 0.07 \\
\hline \multirow{2}{*}{$05-14-14$} & 1010 & Discrete & 2.2 & 6 & NA & - & 0.04 & NA \\
\hline & 1014 & Autosampler & 2.2 & 19 & 10 & - & 0.11 & 0.06 \\
\hline \multirow{2}{*}{$05-22-14$} & 1130 & Discrete & 3.3 & 15 & NA & 79 & 0.14 & NA \\
\hline & 1131 & Autosampler & 3.3 & 26 & 18 & - & 0.23 & 0.16 \\
\hline \multirow[t]{2}{*}{$06-25-14$} & 1205 & Discrete & 1.2 & 7 & NA & - & 0.02 & NA \\
\hline & 1210 & Autosampler & 1.2 & 27 & 15 & - & 0.09 & 0.05 \\
\hline \multirow[t]{2}{*}{ 08-13-14 } & 1130 & Discrete & 1.1 & 11 & NA & - & 0.03 & NA \\
\hline & 1131 & Autosampler & 1.1 & 16 & 9 & - & 0.05 & 0.03 \\
\hline \multirow{2}{*}{$10-01-14$} & 1000 & Discrete & 1.3 & 6 & NA & - & 0.02 & NA \\
\hline & 1001 & Autosampler & 1.4 & 12 & 7 & - & 0.05 & 0.03 \\
\hline \multirow[t]{2}{*}{$03-25-15$} & 1300 & Discrete & 2.5 & 9 & NA & - & 0.06 & NA \\
\hline & 1301 & Autosampler & 2.5 & 9 & 6 & - & 0.06 & 0.04 \\
\hline \multirow[t]{2}{*}{$05-11-15$} & 1100 & Discrete & 2.5 & 13 & NA & - & 0.09 & NA \\
\hline & 1101 & Autosampler & 2.6 & 27 & 19 & - & 0.19 & 0.13 \\
\hline \multirow[t]{2}{*}{$08-12-15$} & 1300 & Discrete & 1.5 & 15 & NA & - & 0.06 & NA \\
\hline & 1302 & Autosampler & 1.5 & 15 & 8 & - & 0.06 & 0.03 \\
\hline
\end{tabular}

${ }^{1}$ The sample pair on 03-06-14 was removed from the autosampler data adjustment analysis due to the large difference in time (and therefore discharge) between the sample autosampler and discrete sample. 

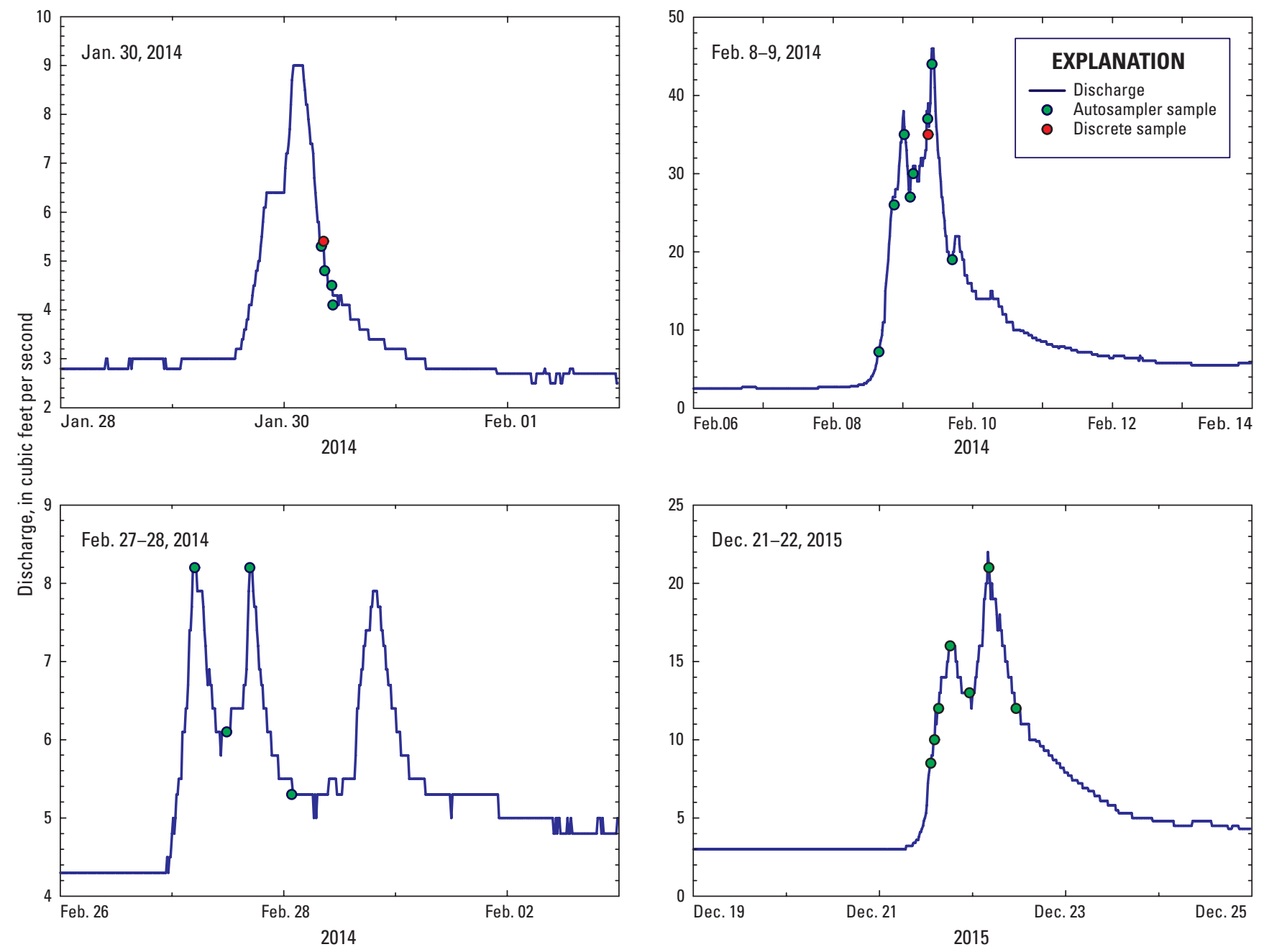

Figure 7. Autosampler and discretely collected samples sent in for suspended-sediment analysis, site 2 (U.S. Geological Survey streamgage 10310500; Clear Creek near Carson City, Nevada), Clear Creek, western Nevada. 


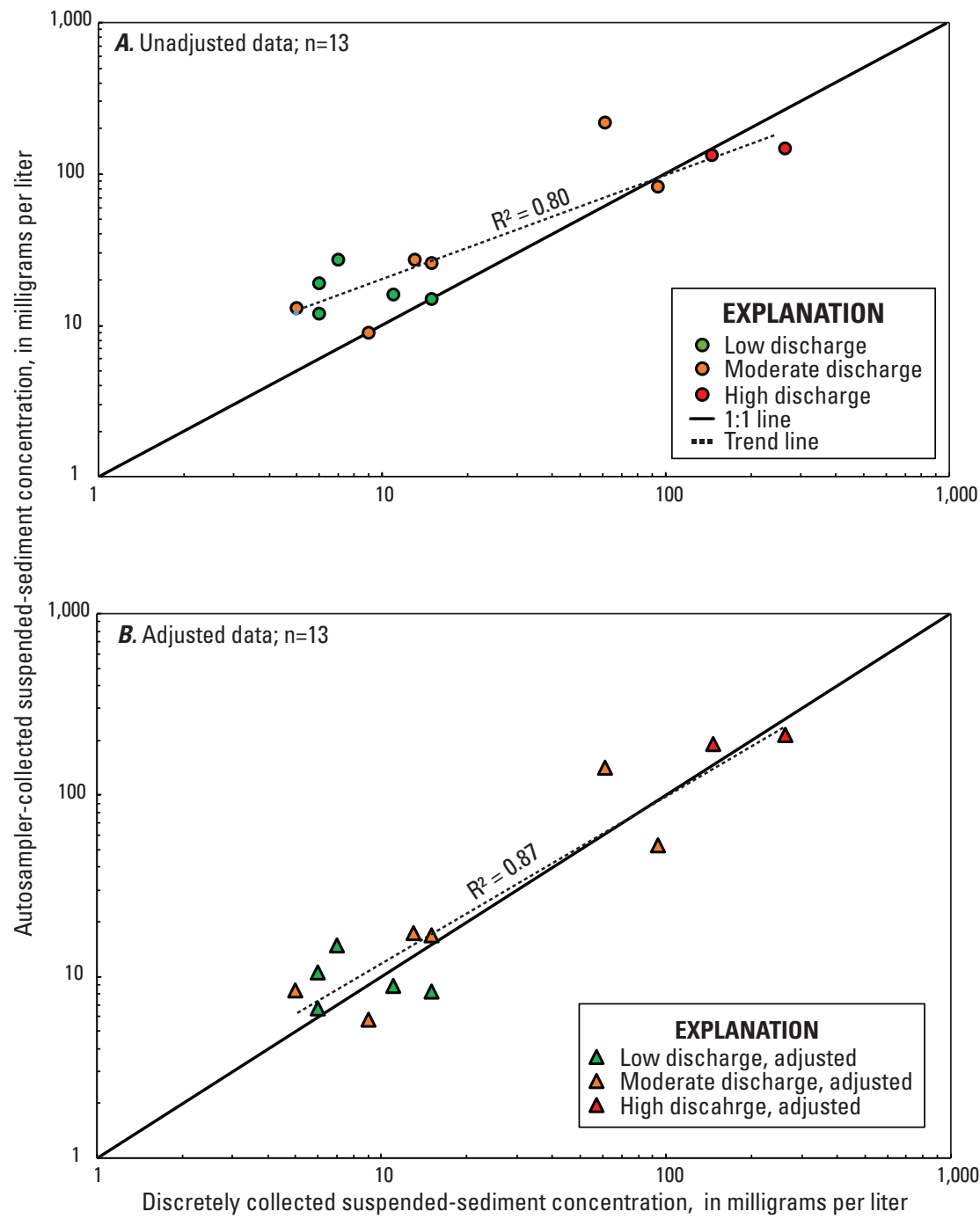

Figure 8. Relation between discrete and autosampler-collected suspended-sediment concentrations for $(A)$ unadjusted data and $(B)$ data adjusted using three flow related cross-section coefficients, Clear Creek, western Nevada. 


\section{Bed-Sediment and Passive Samples}

In 1998, the USGS collaborated with the Federal Highway Administration to summarize the current understanding of semivolatile and volatile organic compounds in highway and urban runoff (Lopes and Dionne, 1998). The collaborative study found that petroleum hydrocarbons, oil and grease, and polycyclic aromatic hydrocarbons (PAHs) contained in crankcase oil and vehicle emissions were generally a major source of semivolatile organic compounds (SVOCs) detected in streams down-gradient from highways and roads. Suspended-sediment concentration, organic carbon content, and distance from highways and roads were the most important factors influencing the concentrations of SVOCs in the streams investigated (Lopes and Dionne, 1998).

Semivolatile organic compounds such as alkylbenzenes and methylated naphthalenes have been associated with used motor oil (Lu and others, 2008). Polycyclic aromatic hydrocarbons (PAHs) commonly associated with used motor oil include naphthalene, benz $(a)$ anthracene, benzo( $a$ )pyrene, benzo(e)pyrene, benzo $(g, h, i)$ perylene, dibenz $(a, c)$ anthracene, fluoranthrene, and phenanthrene (Irwin and others, 1997; Dominguez-Rosado and Pichtel, 2003). Due to advancements in technologies in oil refining processes and engine design, the amount of PAHs introduced into used motor oil during vehicle operation has greatly reduced over the years (Lopes and Dionne, 1998; Shakoane, 2015).

A bed-sediment sample was collected from the Clear Creek streamgage pool at site 2 during September 2014 and sent to the NWQL for analysis of $28 \mathrm{PAH}$ compounds. PAH compounds may associate with suspended sediments (Lopes and Dionne, 1998); however, the analytical method used by the USGS NWQL to evaluate PAH compounds associated with sediments requires a minimum sample weight of $25 \mathrm{~g}$ (Olsen and others, 2004). Since it was not thought likely that $25 \mathrm{~g}$ of suspended sediment would be attainable within a reasonable sample volume or collection time, semi-permeable membrane devices (SPMDs) were deployed to sample for aqueous PAHs that may be entering Clear Creek.

SPMDs are used to passively accumulate moderately to highly lipophilic (nonpolar) substances. Generally, SPMDs are deployed for a period before being retrieved, having their membrane(s) extracted with solvent (dialysis), and then having the extract analyzed for the target suite of nonpolar substances (Wenzel and others, 2004). To characterize the possible contribution of stormwater runoff from the highway and road in proximity to Clear Creek, concentrations of PAH compounds associated with used motor oil were evaluated. SPMDs were used to mimic the organic-carbon (nonpolar; hydrophobic) component of sediment which is the fraction of sediment PAH compounds are attracted to (Smith and others, 1988; Lopes and Dionne, 1998; Huckins and others, 1999).
SPMDs were manufactured by Environmental Sampling Technologies (EST). Each SPMD consisted of two thin-walled lay flat low density polyethylene membrane tubes encasing ultra-high-purity triolein. Each membrane pair was housed in a small metal canister. SPMDs were deployed at site 2four times in 2013 and once in both 2014 and 2015 (table 3). Each deployment consisted of three SPMDs (for a total of six membrane tubes per deployment). SPMDs were secured in the creek channel in such a way as to remain completely submerged underwater without being buried by sediment deposition or exposed to the atmosphere throughout each of the approximate 30-day deployment periods. Field blanks, also consisting of two triolein membrane tubes, were transported and handled in a similar manner as each of the environmental SPMD samples during each deployment as described by Alvarez (2010). A field blank was included during each SPMD deployment; there were a total of six field blanks during the study. Field blanks are used to identify sources of contamination resulting from SPMD manufacturing and materials, atmospheric conditions at the sampling site, transport and storage, processing, and analysis.

Table 3. Specifications for a single semipermeable membrane device.

[Each canister housed two membranes. Site 2 (U.S. Geological Survey streamgage 10310500; Clear Creek near Carson City, Nevada) location shown in figure 1. Abbreviations: SPMD, semipermeable membrane device; LDPE, low density polyethylene; $\mathrm{cm}$, centimeter; $\mu \mathrm{m}$, micrometer; $\mathrm{mL}$, milliter]

\begin{tabular}{lc}
\hline \multicolumn{2}{c}{ SPMD canister and membrane specifications } \\
\hline \multicolumn{1}{c}{ Parameter } & Specification \\
\hline Weight (gram) & 0.885 \\
Length $(\mathrm{cm})$ & 15.5 \\
Width $(\mathrm{cm})$ & $2.5-2.8$ \\
LDPE wall thickness $(\mu \mathrm{m})$ & $75-90$ \\
Triolein volume $(\mathrm{mL})$ & 0.167 \\
\hline SPMD sample collection deployment periods at site 2 \\
\hline & Length of \\
& deployment \\
Deployed & (days) \\
& 31 \\
$03-05-13$ & 30 \\
$04-23-13$ & 31 \\
$08-16-13$ & 29 \\
$11-12-13$ & 32 \\
$03-24-14$ & 104 \\
$06-25-15$ &
\end{tabular}


After deployment, environmental and field blank SPMDs were shipped to EST, the manufacturer, for dialysis. Dialysis is the term used to describe the extraction of substances from SPMD membranes (Wenzel and others, 2004). Through dialysis, compounds were removed from the membranes, composited, and sent to the USGS National Water Quality Laboratory for PAH analysis. Dialysis blanks were prepared at EST by simultaneously processing an equivalent volume of solvent used during the extraction of PAHs from the environmental and field blank SPMDs. Dialysis blanks are used to evaluate sources of potential contamination from processing the SPMD membranes after deployment and from laboratory analysis. Of the 38 SVOCs analyzed, 13 of the PAHs have been associated with used crankcase motor oil (National Research Council, 1983; Irwin and others, 1997; Cvengroš and others, 2015).

\section{Data Evaluation Methods}

The Mann-Whitney Rank-Sum and the paired t-test were used throughout the sediment and water quality data analysis to determine whether two datasets were statistically different from each other. The Mann-Whitney Rank-Sum test was used most often because it is non-parametric and can compare two groups of data without the required assumptions of normality (Helsel and Hirsch, 2002, p. 118). The t-test also was used in the few instances where the two datasets were normally distributed (Helsel and Hirsch, 2002, p. 124). The t-test is more powerful in distinguishing significant differences among data that are normally distributed; however, it requires a normal distribution. The Mann-Whitney Rank-Sum, although not as powerful as the t-test, is more widely applicable to environmental data because, oftentimes, environmental data are not normally distributed. A Spearman's Rank correlation test was also used to assess whether correlations among various parameters were significantly different from one another as represented during each period of evaluation (Cohen and others, 2003, p. 272-274). With all these statistical significance tests, a p-value less than 0.05 was selected as criteria for concluding whether differences between the two datasets was significant. Instances where differences between datasets were significant indicate that sediment transport in Clear Creek is significantly different from baseline and (or) interim conditions. Alternatively, instances where differences between datasets were not significant indicate that the samples collected during 2013-16 show no difference from baseline and (or) interim conditions.

The bed-sediment sample and SPMD extracts collected from site 2 in Clear Creek were analyzed by the USGS NWQL for 28 and 38 PAH compounds, respectively. PAH concentrations were evaluated with respect to the long-term method detection limit for the compounds in bed sediment $(5 \mu \mathrm{g} / \mathrm{kg})$ and the quantification level for SPMD extracts (100 ng/ampoule).

PAH concentrations in each SPMD environmental sample were evaluated to respective dialysis and field blanks. Each environmental SPMD extract was a composite of six membranes; each blank was a composite of two membranes. To compare PAH concentrations found in the environmental SPMD extracts to those of the blanks, each composited SPMD extract concentration was normalized to the number of membranes extracted giving units of nanograms per membrane (ng/membrane).

\section{Sediment Concentration and Transport}

Collection of samples representing a wide range of stream discharges and annual stream conditions is important for understanding the sediment transport characteristics of streams during all flow regimes (Uhrich and Bragg, 2003). As part of this study, samples of suspended and bedload-sediment were collected at the three sample sites during periods of base and high-flow events such as storms, and throughout the snowmelt-runoff period (fig. 9; table 4). All three sites were sampled on the same day starting at the most upstream site and ending at the most downstream site. More suspended-sediment and bedload samples were collected at site 2 than at sites 1 and 3 .

\section{Suspended-Sediment Concentrations}

\section{Discrete Suspended-Sediment Concentrations}

Discrete suspended-sediment samples were collected at all sites during 2013-16 (table 4). During the current study, suspended-sediment concentrations ranged from 1 to $50 \mathrm{mg} / \mathrm{L}$ at site 1 , from 3 to $300 \mathrm{mg} / \mathrm{L}$ at site 2 , and from 2 to $88 \mathrm{mg} / \mathrm{L}$ at site 3 (fig. 10). Generally, from 2004 to 2012, suspendedsediment concentrations found in samples collected at site 2 were higher than in samples collected from either sites 1 or 3 ( $p<0.05$ and $<0.001$, respectively; fig. 10 ; data originates from Seiler and Wood [2009] and Huntington and Savard [2015]). During this study, median suspended-sediment concentrations were lower than those determined for samples collected from 2004 through 2012; however, these were only significant differences at sites 2 and 3 (fig. 10). Lower suspended-sediment concentrations are partly attributed to lower than average discharge during nearly all of 2013-16 (figs. 4, 5, and 6). 


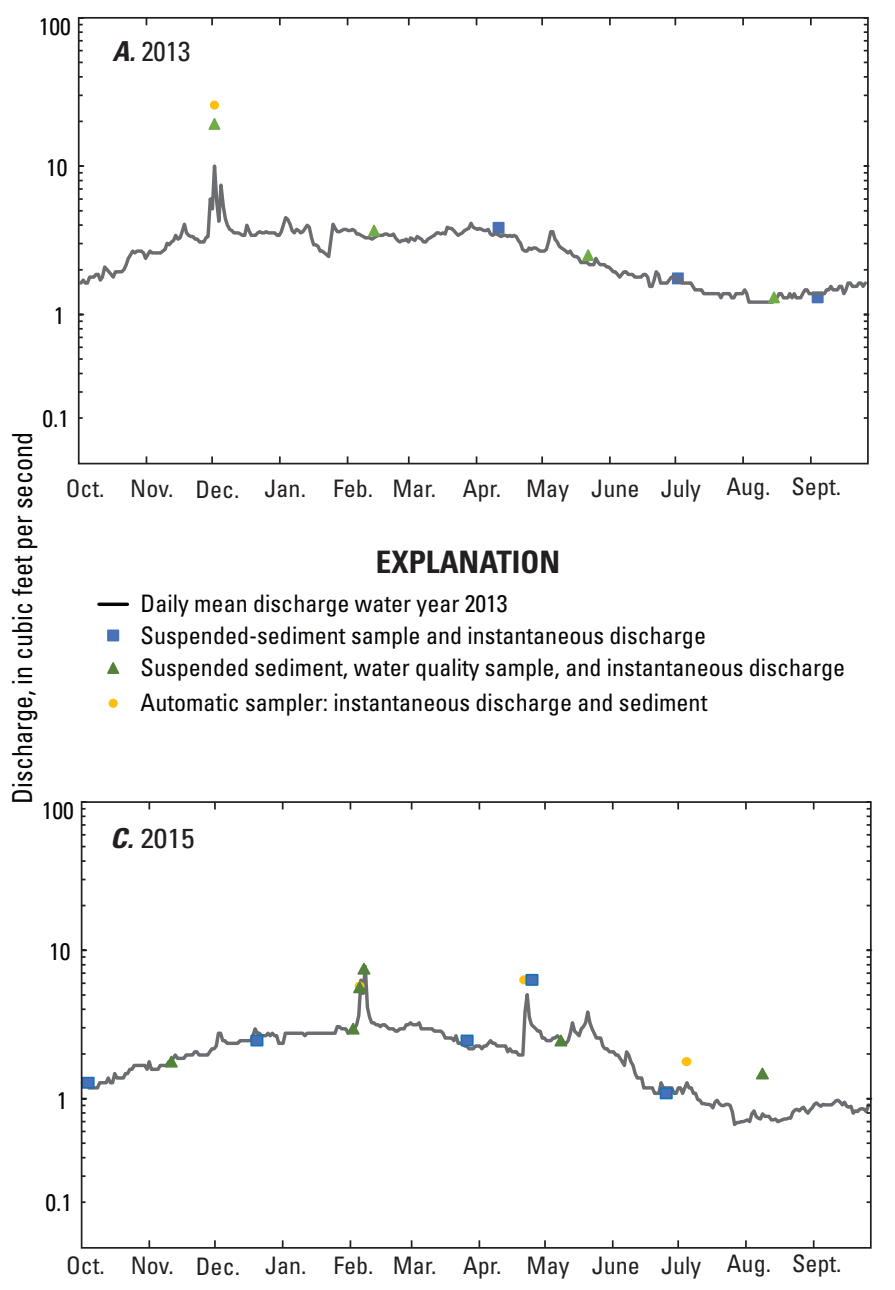

EXPLANATION

- Daily mean discharge water year 2015

- Suspended-sediment sample and instantaneous discharge

- Suspended sediment, water quality sample, and instantaneous discharge

- Automatic sampler: instantaneous discharge and sediment
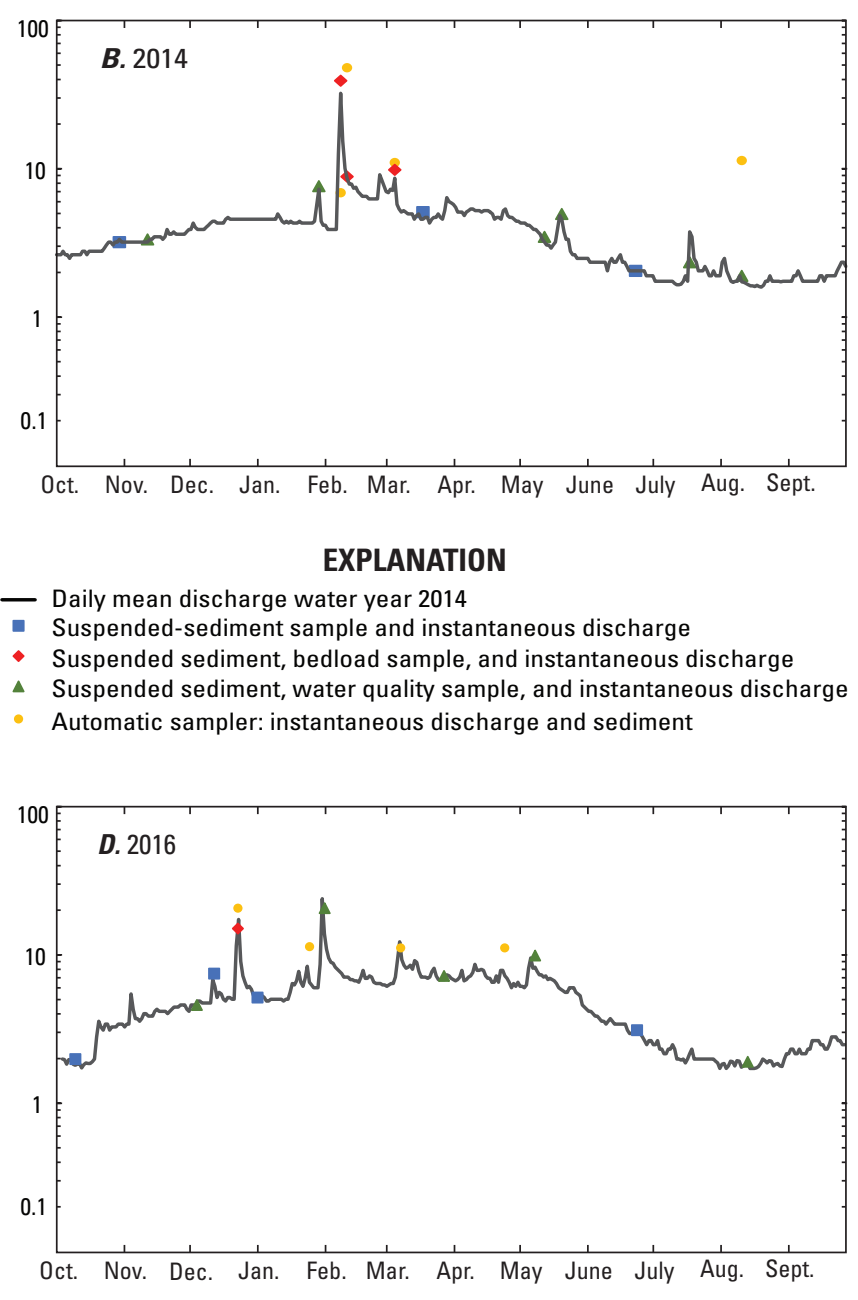

EXPLANATION

- Daily mean discharge water year 2016

- Suspended-sediment sample and instantaneous discharge

- Suspended sediment, bedload sample, and instantaneous discharge

- Suspended sediment, water quality sample, and instantaneous discharge

- Automatic sampler: instantaneous discharge and sediment

Figure 9. Daily mean discharge and types of samples collected at site 2 (U.S. Geological Survey streamgage 10310500; Clear Creek near Carson City, Nevada) for water years $(A)$ 2013, (B) 2014, (C) 2015, and (D) 2016. 
Table 4. Discharge, field measurements, and discrete suspended-sediment concentrations, characteristics, and load for samples collected from Clear Creek, Western Nevada, water years 2013-16.

[Location of sampling sites shown in figure 1. U.S. Geological Survey streamgage No. given in parentheses after site name. Sample counts and median values represent only suspended-sediment samples that had sand-break analyses. Date: Month-day-year. Time: 24 -hour clock. Abbreviations: ${ }^{\circ} \mathrm{C}$, degrees Celsius; $\mathrm{ft}^{3} / \mathrm{s}$, cubic feet per second; $\mathrm{mg} / \mathrm{L}$, milligram per liter; $\mu \mathrm{S} / \mathrm{cm}$ at $25^{\circ} \mathrm{C}$, microsiemen per centimeter; ton/d, ton per day; -, no data available]

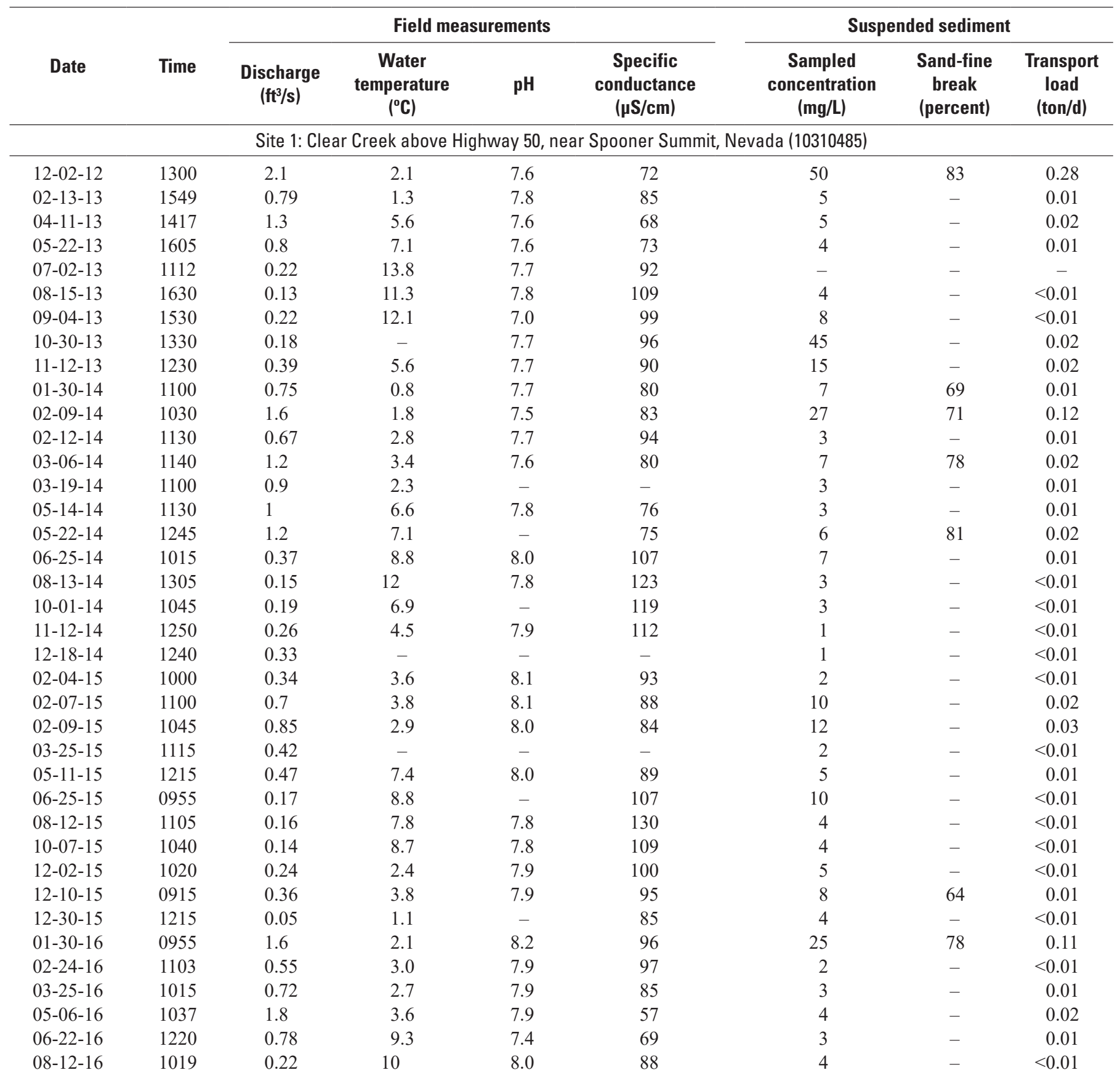


Table 4. Discharge, field measurements, and discrete suspended-sediment concentrations, characteristics, and load for samples collected from Clear Creek, Western Nevada, water years 2013-16._Continued

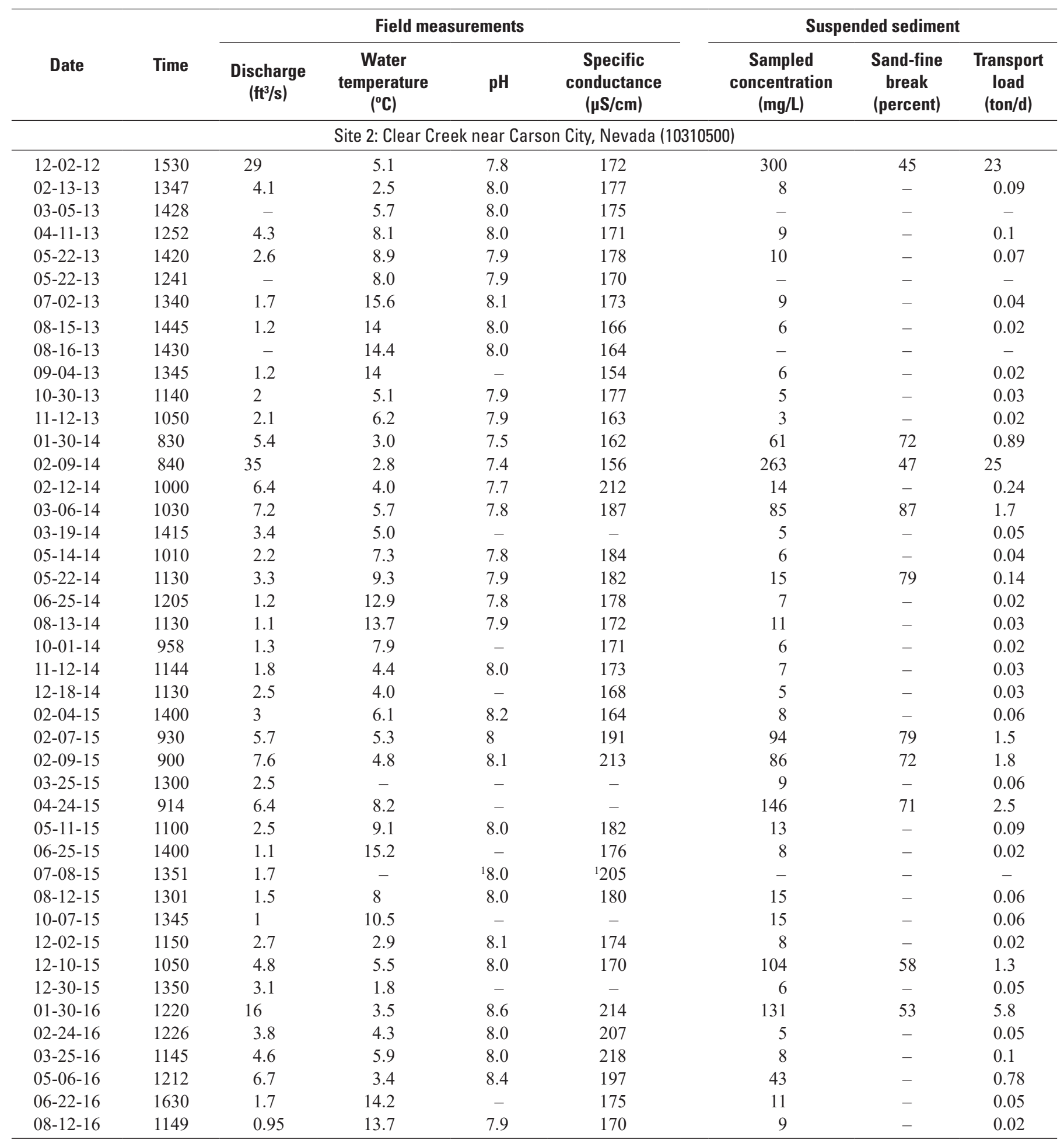


Table 4. Discharge, field measurements, and discrete suspended-sediment concentrations, characteristics, and load for samples collected from Clear Creek, Western Nevada, water years 2013-16. - Continued

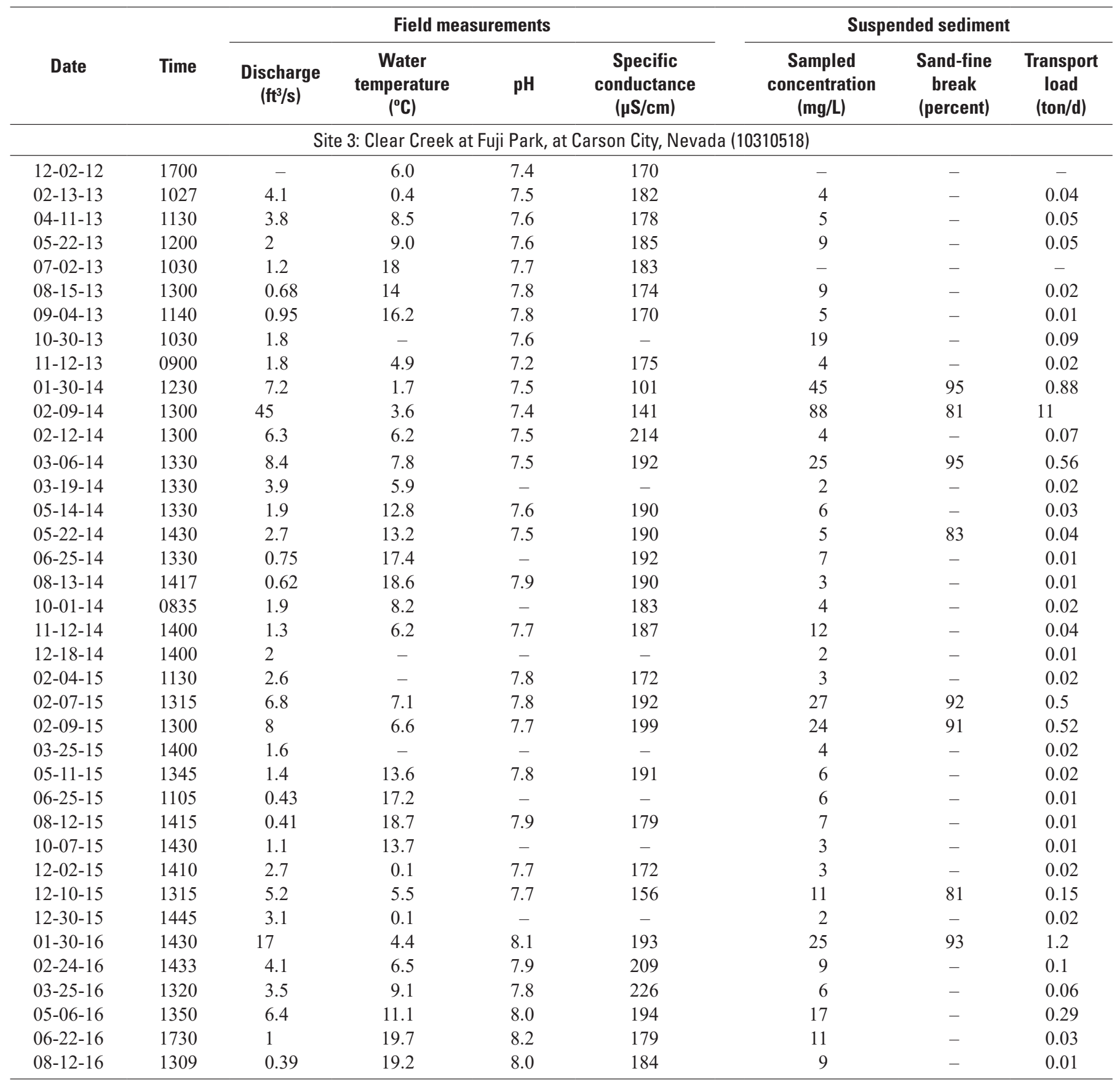

${ }^{1}$ Laboratory value, field value not available. 

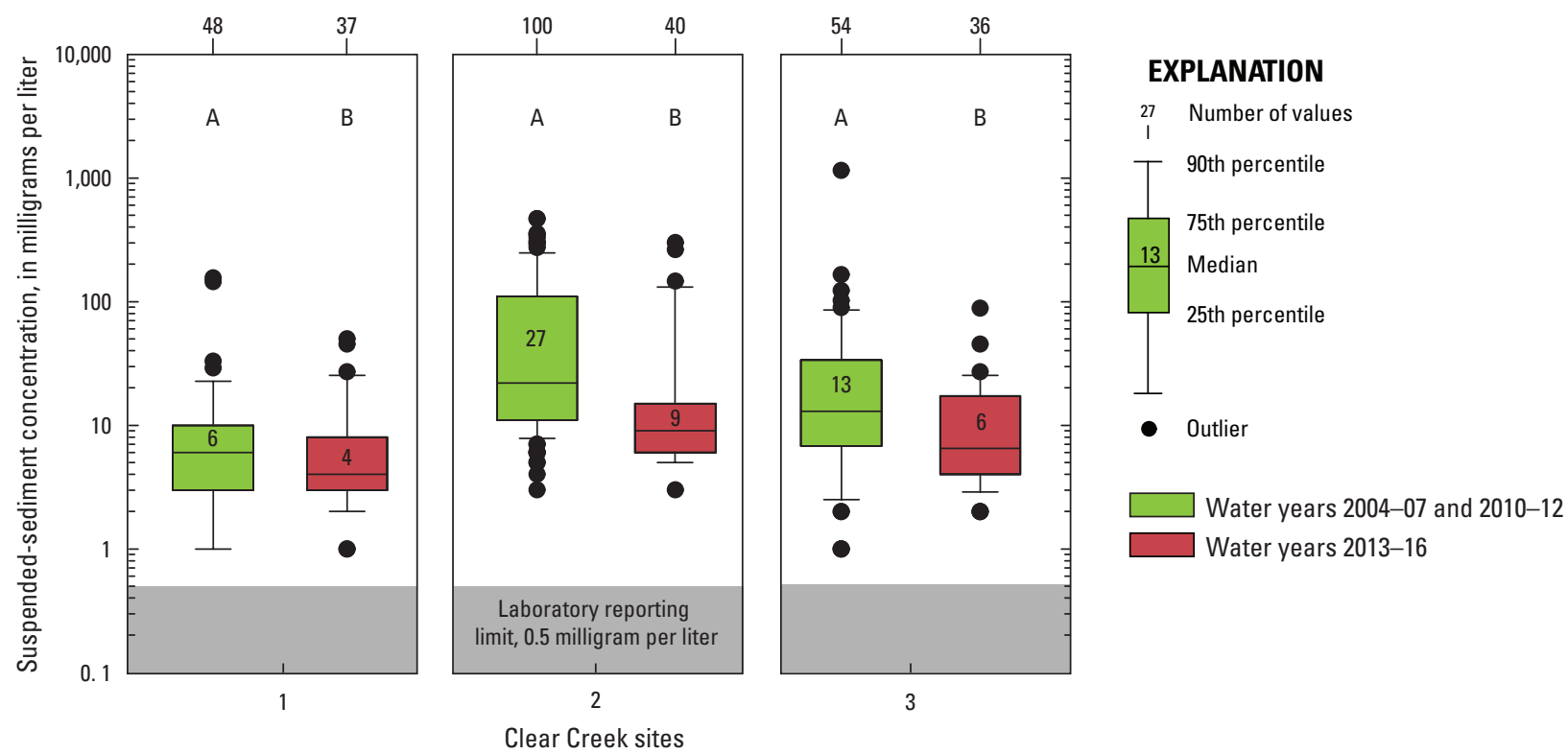

Figure 10. Suspended-sediment concentrations at sites 1 (U.S. Geological Survey reference site 10310485; Clear Creek above Highway 50, near Spooner Summit, Nevada), 2 (U.S. Geological Survey streamgage 10310500; Clear Creek near Carson City, Nevada), and 3 (U.S. Geological Survey site 10310518; Clear Creek at Fuji Park, at Carson City, Nevada), Clear Creek, western Nevada, water years 2004-07, 2010-12, and 2013-16.

Because sand can contribute more to the mass per unit volume of sample than silt, it is important to characterize the proportions of each in a sample (Seiler and Wood, 2009, p. 19). Select suspended-sediment samples were analyzed for the percentage weight of sample finer than $0.0625 \mathrm{~mm}$, also known as the sand-fine break. The sand-fine break represents the sediment diameter threshold between sand and silt and is expressed as the percent of suspended material representative of silt-sized particles (including clays and colloids). Selection of samples targeted for the sand-fine break analysis was determined after collection of the sample. The sand-fine break analysis was requested for suspended-sediment samples if substantial amounts of settled sediment was visible at the bottom of the sediment bottles. At all sites, most suspended sediment was silt-sized or finer (table 5). Median suspended-sediment concentrations in table 5 were calculated only from samples that also were analyzed for sand-fine break, which was a subset of the larger suspended-sediment dataset. Although data were limited, the percentage of silt content generally increased with distance downstream. This is likely due to the larger sand-sized particles being deposited in the lower parts of the creek where streambed gradients are lower, and therefore the silt fraction represents a greater parts of the suspended-sediment sample. The median percent silt fraction at each site also has generally increased over time from 2004 07 to $2010-12$ and from 2010 to 2012 to the current study; the increase was significant at sites $1(\mathrm{p}=0.012)$ and $3(\mathrm{p}=0.016$, table 5). The increase in silt fraction at site 2 significantly increased between the 2004-07 and the 2010-12 study only though $(p<0.001)$. Increasing silt, which alternatively means less sand, may be due to lower than average discharges during the interim and current study periods. 


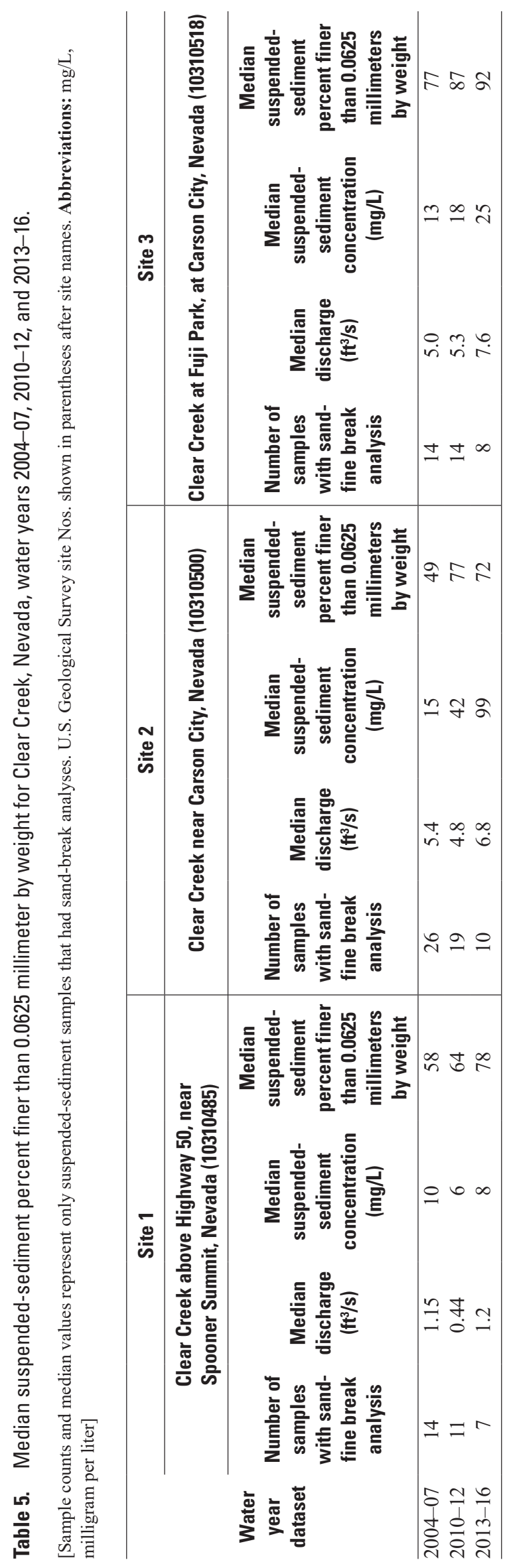




\section{Storm-Event Autosampler Sample Concentrations}

Between 2004 and 2016, 140 discretely collected suspended-sediment samples were collected from Clear Creek at site 2. Suspended-sediment concentrations ranged from 3 to $468 \mathrm{mg} / \mathrm{L}$ under varying stream discharges ranging from 0.79 to $110 \mathrm{ft}^{3} / \mathrm{s}$ (table 6). The installation of the automatic sampler in 2014, made an additional 51 samples possible under unsafe field conditions and during times not feasible for field staff to be on site (tables 2 and 6). Cross-section adjusted autosampler-collected suspended-sediment concentrations ranged from 14 to $4,479 \mathrm{mg} / \mathrm{L}$ during discharges ranging from 1.1 to $44 \mathrm{ft}^{3} / \mathrm{s}$ (table 6 ). Because the majority of these autosampler samples were collected during storm events, discharges and associated suspended-sediment concentrations were significantly greater than discretely collected samples (fig. 11). Sampling over storm events with an automated sampler has helped to characterize sediment transport in Clear Creek during storm events.

Table 6. Comparison of discrete and cross-section adjusted suspended-sediment samples at site 2 (U.S. Geological Survey streamgage 10310500; Clear Creek near Carson City, Nevada) during each year of study, Clear Creek, western Nevada, 2004-16.

[Autosampler-collected samples-Range of suspended-sediment concentration, low/high: Adjusted concentrations as seen in table 2. Abbreviations: $\mathrm{ft}^{3} / \mathrm{s}$, cubic feet per second; $\mathrm{mg} / \mathrm{L}$, milligram per liter; ton/d, ton per day; NA, not applicable]

\begin{tabular}{|c|c|c|c|c|c|c|}
\hline & \multicolumn{3}{|c|}{ Discretely collected samples } & \multicolumn{3}{|c|}{ Autosampler-collected samples } \\
\hline Water year & $\begin{array}{l}\text { Number of } \\
\text { samples } \\
\text { collected }\end{array}$ & $\begin{array}{l}\text { Range of } \\
\text { suspended- } \\
\text { sediment } \\
\text { concentration, } \\
\text { low/high } \\
\text { (mg/L) }\end{array}$ & $\begin{array}{l}\text { Range in } \\
\text { associated } \\
\text { discharge, } \\
\text { low/high } \\
\left(\mathrm{ft}^{3} / \mathrm{s}\right)\end{array}$ & $\begin{array}{l}\text { Number of } \\
\text { samples } \\
\text { collected }\end{array}$ & $\begin{array}{l}\text { Range of } \\
\text { suspended- } \\
\text { sediment } \\
\text { concentration, } \\
\text { low/high } \\
\text { (mg/L) }\end{array}$ & $\begin{array}{l}\text { Range in } \\
\text { associated } \\
\text { discharge, } \\
\text { low/high } \\
\left(\mathrm{ft}^{3} / \mathrm{s}\right)\end{array}$ \\
\hline 2004 & 14 & $\begin{array}{r}8 \\
107\end{array}$ & $\begin{array}{l}1.3 \\
6.6\end{array}$ & NA & NA & NA \\
\hline 2005 & 13 & $\begin{array}{r}9 \\
228\end{array}$ & $\begin{array}{l}1.6 \\
9.7\end{array}$ & NA & NA & NA \\
\hline 2006 & 17 & $\begin{array}{r}8 \\
468 \\
\end{array}$ & $\begin{array}{c}2.4 \\
110\end{array}$ & NA & NA & NA \\
\hline 2007 & 23 & $\begin{array}{r}3 \\
465 \\
\end{array}$ & $\begin{array}{l}1.7 \\
14\end{array}$ & NA & NA & NA \\
\hline 2010 & 9 & $\begin{array}{r}5 \\
183 \\
\end{array}$ & $\begin{array}{l}0.79 \\
5.8\end{array}$ & NA & NA & NA \\
\hline 2011 & 19 & $\begin{array}{r}9 \\
348 \\
\end{array}$ & $\begin{array}{l}2.8 \\
65 \\
\end{array}$ & NA & NA & NA \\
\hline 2012 & 5 & $\begin{array}{r}4 \\
356 \\
\end{array}$ & $\begin{array}{c}4.8 \\
17 \\
\end{array}$ & NA & NA & NA \\
\hline 2013 & 7 & $\begin{array}{r}6 \\
300 \\
\end{array}$ & $\begin{array}{c}1.2 \\
29 \\
\end{array}$ & NA & NA & NA \\
\hline 2014 & 11 & $\begin{array}{r}3 \\
175 \\
\end{array}$ & $\begin{array}{l}1.1 \\
7.2 \\
\end{array}$ & 22 & $\begin{array}{r}46 \\
4,479 \\
\end{array}$ & $\begin{array}{c}1.4 \\
44 \\
\end{array}$ \\
\hline 2015 & 11 & $\begin{array}{r}5 \\
146 \\
\end{array}$ & $\begin{array}{l}1.1 \\
7.6\end{array}$ & 13 & $\begin{array}{r}14 \\
307\end{array}$ & $\begin{array}{l}1.1 \\
6.4\end{array}$ \\
\hline 2016 & 11 & $\begin{array}{r}5 \\
131\end{array}$ & $\begin{array}{r}1 \\
16\end{array}$ & 16 & $\begin{array}{r}30 \\
803\end{array}$ & $\begin{array}{c}5.8 \\
21\end{array}$ \\
\hline $\begin{array}{l}\text { Period of } \\
\text { record, } \\
2004-16\end{array}$ & 140 & $\begin{array}{r}3 \\
468\end{array}$ & $\begin{array}{l}0.79 \\
110\end{array}$ & 51 & $\begin{array}{r}14 \\
4,479\end{array}$ & $\begin{array}{l}1.1 \\
44\end{array}$ \\
\hline
\end{tabular}




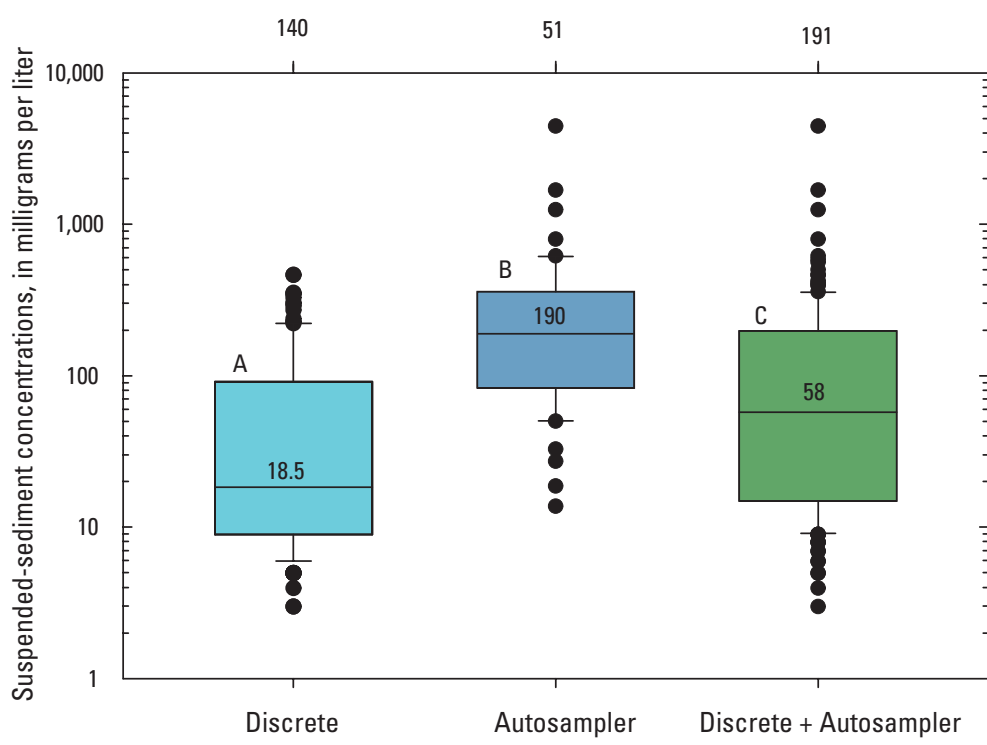

\section{EXPLANATION}

27 Number of values

T 90th percentile

75th percentile

58 Median

25th percentile

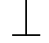

- Outlier

A Median concentrations that are significantly different from each other are represented by different letters.

Figure 11. Comparison of discrete and cross-section adjusted autosampler suspended-sediment concentrations, site 2 (U.S. Geological Survey streamgage 10310500; Clear Creek near Carson City, Nevada), Clear Creek, western Nevada, 2004-07 and 2010-16.

The location and orientation of the autosampler intake can have a large influence on the suspended-sediment concentration and the particle size distribution of the sample. Most autosampler-collected suspended-sediment samples were evaluated for sand break, although only a few of those also had a paired discrete sample that was analyzed for sand break $(\mathrm{n}=4$, table 2 and fig. 12). Paired discrete and autosampler suspended-sediment samples were determined as those samples that were collected during a similar flow and within 30 minutes. The percentage of silt present in the discrete sample was generally similar to the autosampler-collected sample, with the exception of the February 9, 2014 storm sample, where the autosampler sample contained less silt than the discrete sample (by weight) (table 2).

\section{Sediment Loads}

\section{Suspended-Sediment Loads}

Suspended-sediment loads, in ton per day (ton/d), were calculated by multiplying paired instantaneous stream discharge and suspended-sediment concentration. During this study (2013-16), suspended-sediment loads ranged from less than 0.01 to 0.28 ton/ $\mathrm{d}$ at site $1,0.02$ to $42.8 \mathrm{ton} / \mathrm{d}$ at site 2 (including autosampler adjusted load), and 0.01 to 11 ton/d at site 3 (fig. 13A, tables 2 [autosampler] and 4 [discrete]). The highest suspended-sediment load observed at site 2 (42.8 ton/d) during a precipitation event that occurred in early February 2014 (fig. $13 A$ and table 2). The highest load during the period of record was during a storm event on December 31, 2005, which produced a suspended-sediment load of 86 tons/d in Clear Creek when discharge reached $110 \mathrm{ft}^{3} / \mathrm{s}$ (fig. 13B; Seiler and Wood, 2009).

Site 2 cross-section adjusted autosampler data were not used when comparing suspended-sediment loads between sites since autosamplers were not used at sites 1 and 3 . As found in previous studies, suspended-sediment loads were almost always lower at sites 1 and 3 than at site 2 (fig. 13A), indicating that sediment was being mobilized between sites 1 and 2 and deposited between sites 2 and 3 (fig. 2; Seiler and Wood, 2009, fig. 19 and p. 19). Historically, there was no significant difference between loads at site 2 and 3 (Huntington and Savard, 2015, p. 19). However, with continued sampling during the current study, suspended-sediment loads at site 3 are significantly lower than at site $2(\mathrm{P}<0.001$, fig. $13 B)$, which further supports sediment deposition occurring between sites 2 and 3 where the stream gradient becomes more gradual (fig. 2). When all data is compiled for the period of record, each site is significantly different than the others, with the lowest loads at site 1 and highest loads at site 2 (fig. 13B). 


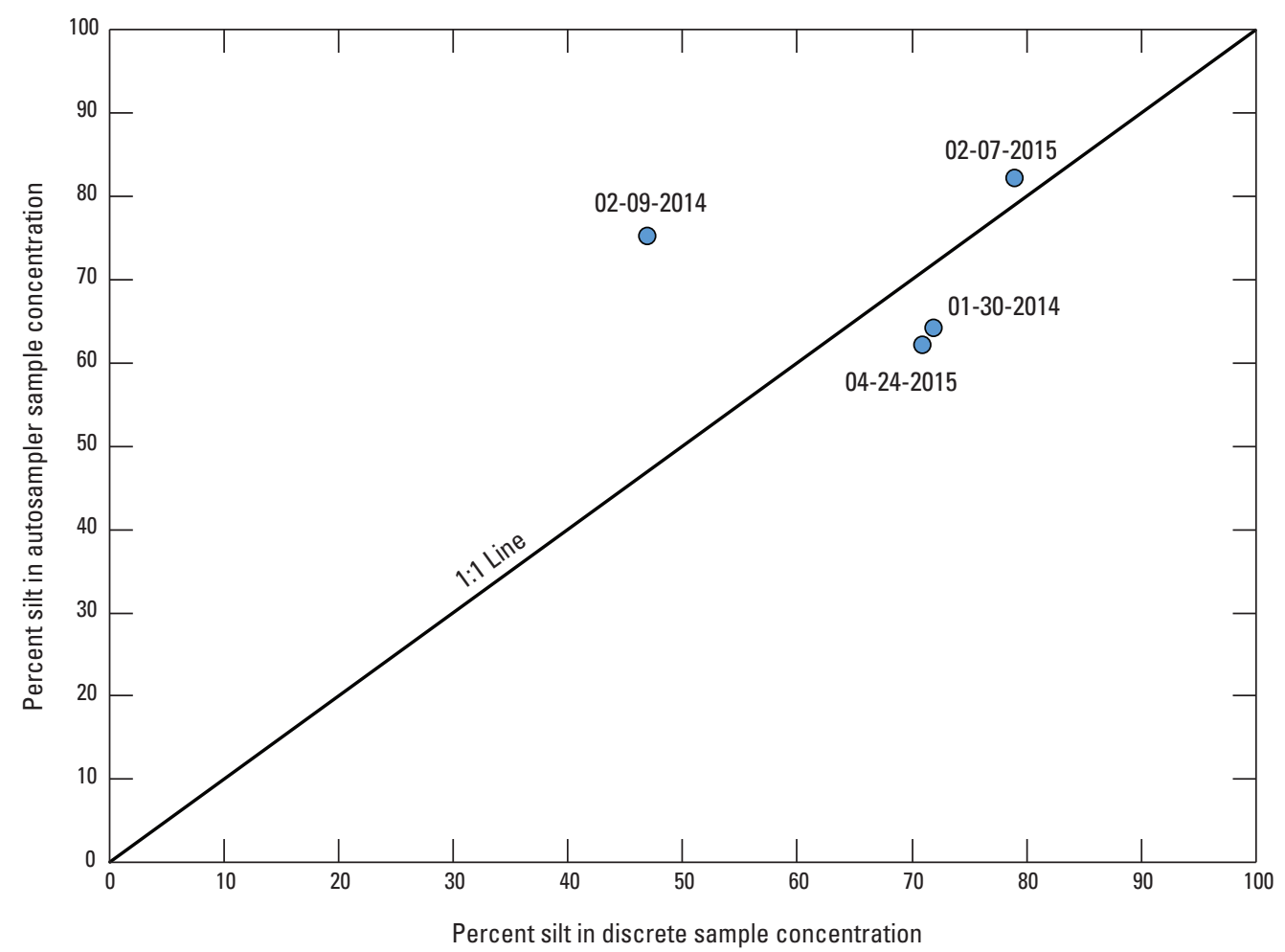

Figure 12. Percentage of silt as determined using the sand-fine break analysis in suspended-sediment samples collected discretely and using the autosampler at site 2 (U.S. Geological Survey streamgage 10310500; Clear Creek near Carson City, Nevada), Clear Creek, western Nevada, 2014-16. 


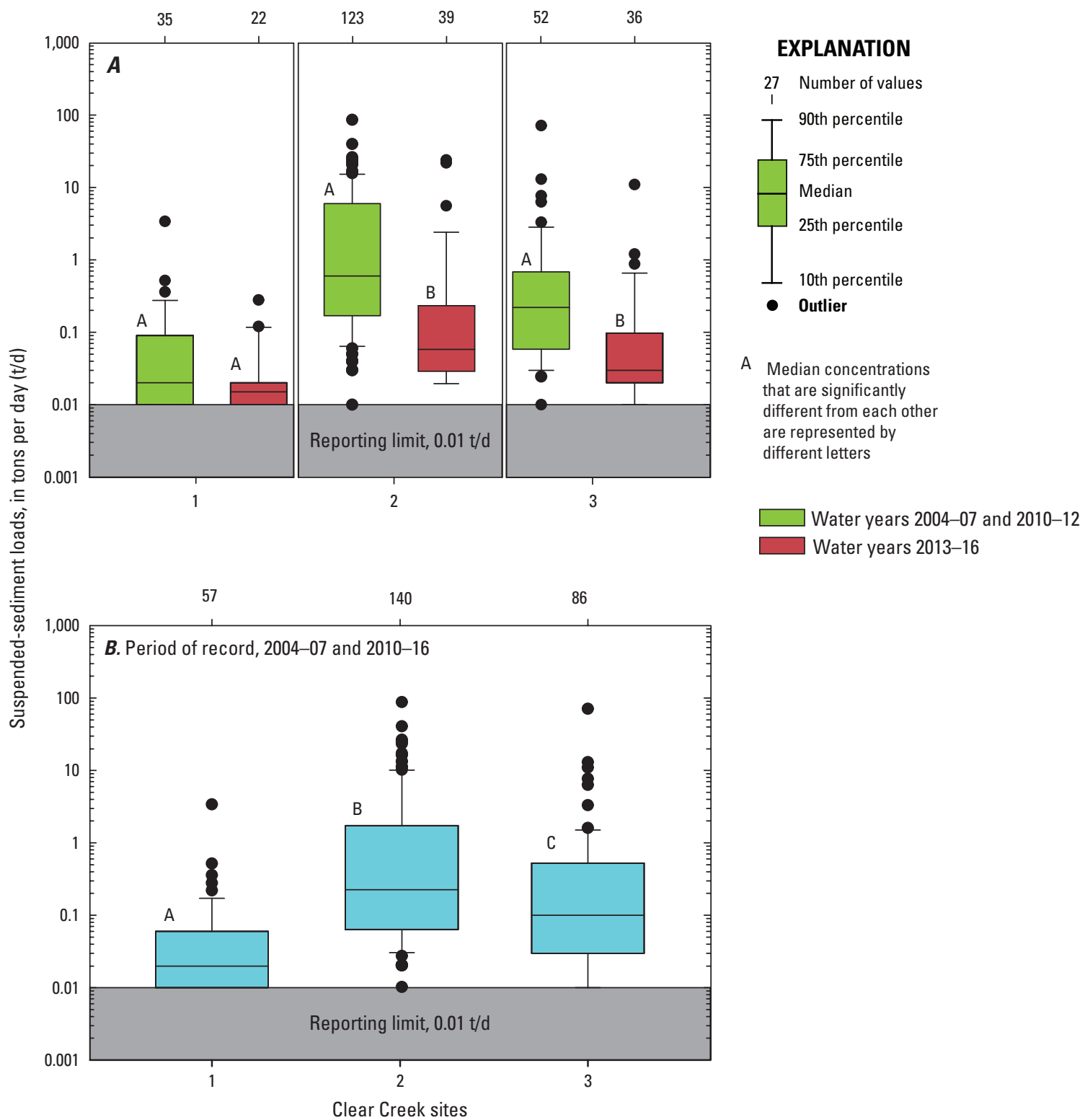

Figure 13. Distribution of suspended-sediment loads at sites 1 (U.S. Geological Survey reference site 10310485; Clear Creek above Highway 50 near Spooner Summit, Nevada), 2 (U.S. Geological Survey streamgage 10310500; Clear Creek near Carson City, Nevada), and 3 (U.S. Geological Survey site 10310518; Clear Crek at Fuji Park at Carson City, Nevada) on Clear Creek, western Nevada, (A) 2004-07, 2010-12, and 2013-16, and (B) 2004-16 (all data). 
Analyzing discrete suspended-sediment loads with associated instantaneous discharge helps characterize Clear Creek sediment-transport dynamics. The same logarithm transformation analysis between suspended-sediment loads and discharge that was done by Seiler and Wood (2009) and Huntington and Savard (2015) was done for this study using all load data available for each Clear Creek site (fig. 14). Data were $\log$ transformed to aid in normalizing the data.

As data collection continues and sample sizes increase, trends analysis and interpretation can become more conclusive regarding suspended-sediment loads in Clear Creek. At site 1 , suspended-sediment loads have been relatively low due to lower discharges in the upper drainage basin. The regression shows there were no significant differences between any of the three datasets and that discharge at site 1 accounts for about 45 percent of the variability in the entire dataset (fig. 14A). For comparison to past studies and to other sites, only discrete samples were used in the regression at site 2 (fig. 14B). However, a regression including autosampler data points were added to show how previous assessments were not able to capture the storm event loads, that storm event loads may have been previously underestimated, to highlight the importance of storm (high flow) suspended-sediment transport, and to show how the inclusion of storm event loads change the regression. Although loads were significantly lower during 2013-16 (fig. 13A, site 2), there was no significant changes in load trends, meaning the slopes of regressions have not significantly changed. At site 3 there was no significant difference in loads between the 2004-07 and the 2010-12 datasets (Huntington and Savard, 2015); however, current dataset loads have significantly decreased since 2012 ( $\mathrm{P}<0.001$, fig. $13 A$, site 3 and fig. $14 C$ ). Lower than average streamflow in Clear Creek has had a substantial effect on suspended-sediment loads at sites 2 and 3.

Suspended-sediment loads were plotted with associated Clear Creek discharge in a flow duration format to better understand how suspended-sediment loads at each site vary under different discharge conditions using the entire period of discharge/suspended-sediment load record (fig. 15A-C; Seiler and Wood, 2009; Huntington and Savard, 2015). Median suspended-sediment loads are almost always lower at sites 1 and 3 than at site 2 during all discharges conditions $(\mathrm{p}<0.05)$. New data (2013-16) continues to support Seiler and Wood
(2009) findings that sediment deposition continues to occur between sites 2 and 3 even during high discharge (when site 2 discharge exceeds $8.2 \mathrm{ft}^{3} / \mathrm{s}$ ).

Huntington and Savard (2015) found that suspended-sediment loads at each site were similar under all discharge conditions except during periods of high discharge. During this study, a greater distinction between suspended-sediment transport under low and moderate flow conditions were observed (figs. $15 A-C$ ).

At site 1, suspended-sediment loads during low flows exceeding the 75 th percentile $\left(0.05-0.26 \mathrm{ft}^{3} / \mathrm{s}\right)$ were largely negligible since a load of zero was calculated for 17 of 19 samples (fig. 15A). Suspended-sediment loads become significantly greater under moderate discharge conditions $\left(0.29-1.3 \mathrm{ft}^{3} / \mathrm{s}\right)$ and ranged from 0.01 to 0.36 tons $/ \mathrm{d}(\mathrm{p}=0.003$; fig. 15A). Discharges within the $0-25$ th percentile of flow at site 1 (equal to or exceeding $1.4 \mathrm{ft}^{3} / \mathrm{s}$ ), produced significantly higher suspended-sediment loads that ranged from 0 to 3.4 ton/d $(\mathrm{p}<0.001)$.

At site 2, suspended-sediment loads associated with low flows exceeding the 75 th percentile $\left(0.79-2.9 \mathrm{ft}^{3} / \mathrm{s}\right)$ ranged from 0.01 to 2.36 ton/d (fig. 15B). Suspended-sediment loads associated with moderate discharges $\left(3-7.9 \mathrm{ft}^{3} / \mathrm{s}\right)$ were statistically greater $(\mathrm{p}<0.001)$ than those observed with low flows and ranged from 0.04 to 14.7 ton/d. At site 2, discharges greater than $8 \mathrm{ft}^{3} / \mathrm{s}$ produced suspended-sediment loads between 0.61 and 42.8 ton/d. Although the highest load sampled, 86 ton/d, occurred when discharge reached $110 \mathrm{ft}^{3} / \mathrm{s}$, large loads are not always associated with the highest discharges in Clear Creek. Precipitation events following dry periods can often flush larger volumes of sediment into the creek due to the highly erodible decomposed-granite soils in the drainage basin. For example, an outlier load of 33.9 ton/d resulted from a summer thunderstorm that produced a discharge of $2.8 \mathrm{ft}^{3} / \mathrm{d}$ in July 2014 (considered a lower discharge; fig. 15B; see section, "Fire chemistry").

At site 3, suspended-sediment loads exceeding the 75th percentile (low discharge zone, ranging from 0.4 to $1.9 \mathrm{ft}^{3} / \mathrm{s}$ ) were quite low, ranging from 0.01 to 0.09 ton/d (fig. $15 C$ ). Moderate zone discharges $\left(2-7.4 \mathrm{ft}^{3} / \mathrm{d}\right)$ produced suspendedsediment loads from 0.01 to $1.6 \mathrm{ton} / \mathrm{d}$, while high zone discharges $\left(>7.4-45 \mathrm{ft}^{3} / \mathrm{d}\right)$ produced suspended-sediment loads from 0.5 to 11 ton/d. An outlier of 71 ton/d was observed in May 2006 when discharge at site 3 reached $23 \mathrm{ft}^{3} / \mathrm{s}$. 
A. Site 1 (U.S. Geological Survey reference site10310485; Clear Creek above Highway 50, near Spooner Summit, Nevada)

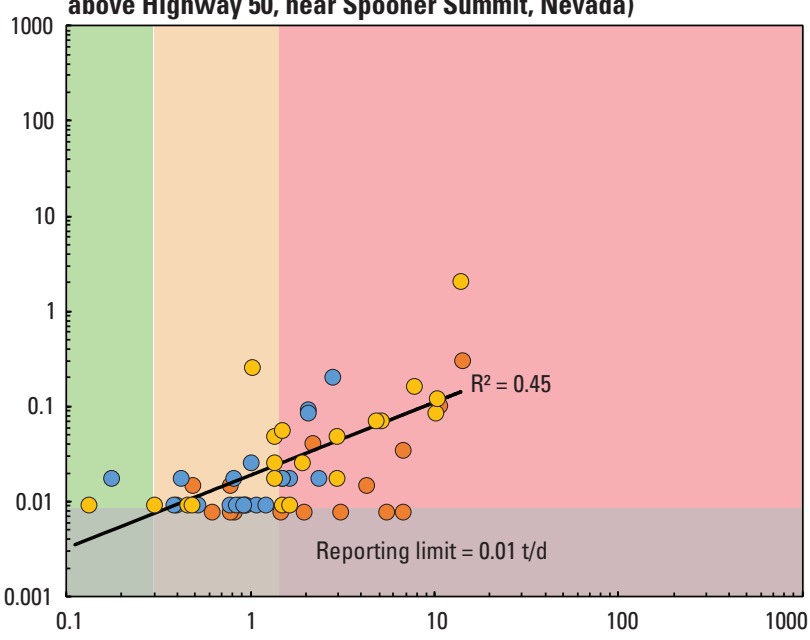

B. Site 2 (U.S. Geological Survey streamgage 10310500; Clear Creek near Carson City, Nevada)

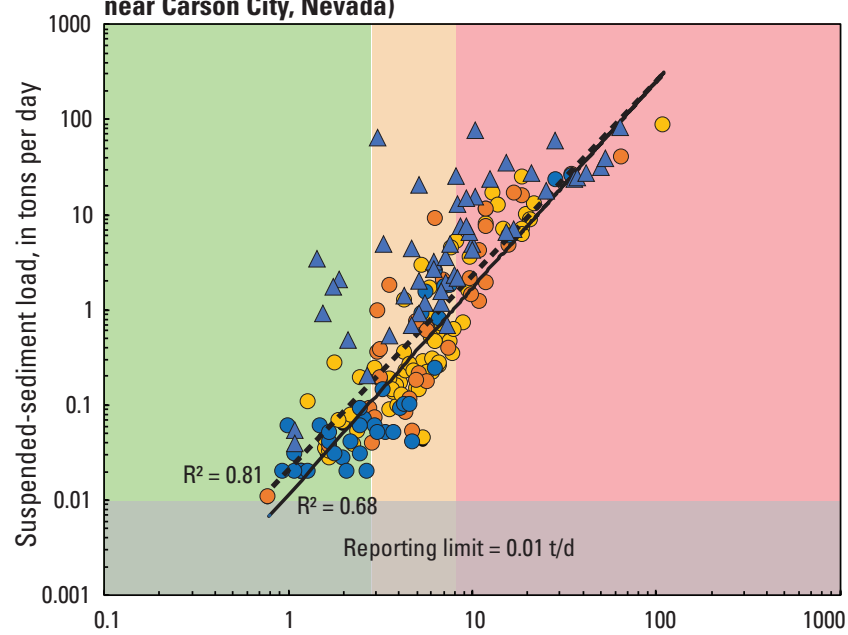

C. Site 3 (U.S. Geological Survey site 10310518; Clear Creek at Fuji Park, at Carson City, Nevada)

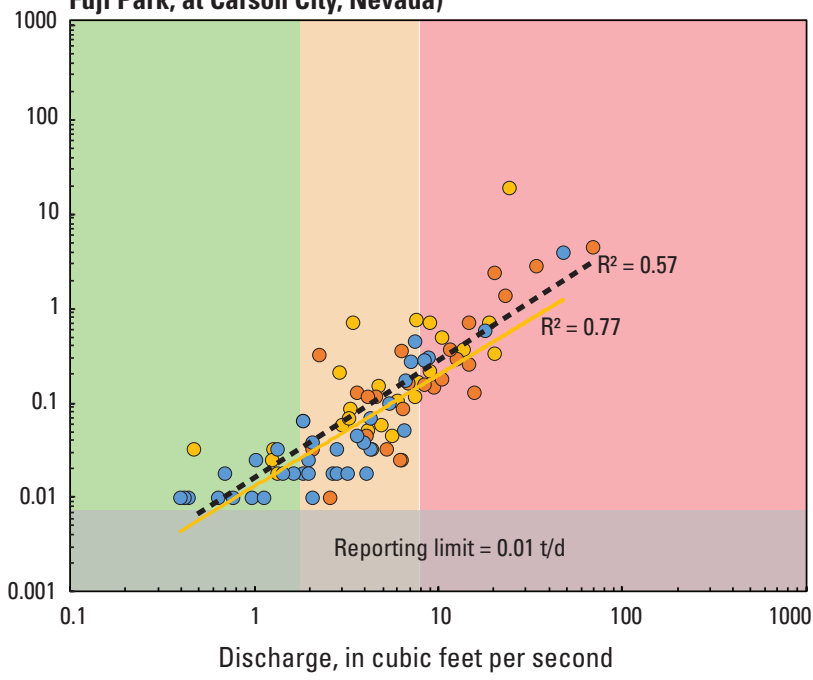

\section{EXPLANATION}

$\square$ Low discharge, $\leq 0.29 \mathrm{ft}^{3} / \mathrm{s}$

$\square$ Moderate discharge, $0.29-1.4 \mathrm{ft}^{3} / \mathrm{s}$

$\square$ High discharge, $>1.4 \mathrm{ft}^{3} / \mathrm{s}$

- Regression, all data

-2004-07

- 2010-12

2013-16

\section{EXPLANATION}

$\square$ Low discharge, $\leq 2.9 \mathrm{ft}^{3} / \mathrm{s}$

$\square$ Moderate discharge, $2.9-8.1 \mathrm{ft}^{3} / \mathrm{s}$

$\square$ High discharge, $>8.1 \mathrm{ft}^{3} / \mathrm{s}$

- Regression, relation with discrete and autosampler data, rate $=10^{\wedge}\left(2.05^{*} \log (\text { discharge })-1.67\right)^{*} 3.34, \mathrm{R}^{2}=0.68$

... Regression, relation with discrete data only, rate $=10^{\wedge}\left(2.17^{*} \log (\text { discharge })-1.95\right)^{*} 1.58, R^{2}=0.81$

○ 2004-07

- 2010-12

- 2013-16, discrete

$\triangle$ 2013-16, autosampler

\section{EXPLANATION}

$\square$ Low discharge, $\leq 1.9 \mathrm{ft}^{3} / \mathrm{s}$

$\square$ Moderate discharge, 1.9-8.0 ft $\mathrm{t}^{3} / \mathrm{s}$

$\square$ High discharge, $>8.0 \mathrm{ft}^{3} / \mathrm{s}$

-.. Regression, relation with 2004-12 data, rate $=10^{\wedge}\left(0.38^{*} \log\right.$ (discharge) $-1.00^{*} 0.077, \mathrm{R}^{2}=0.57$

- Regression, relation with 2013-16 data, rate $=10^{\wedge}\left(0.55^{*} \log (\text { discharge })-1.10\right)^{*} 0.007, \mathrm{R}^{2}=0.77$

○ 2004-07

- 2010-12

- 2013-16

Figure 14. Relation between suspended-sediment load and instantaneous discharge for $(A)$ site $1,(B)$ site 2, and $(C)$ site 3, Clear Creek, western Nevada. 
A. Site 1

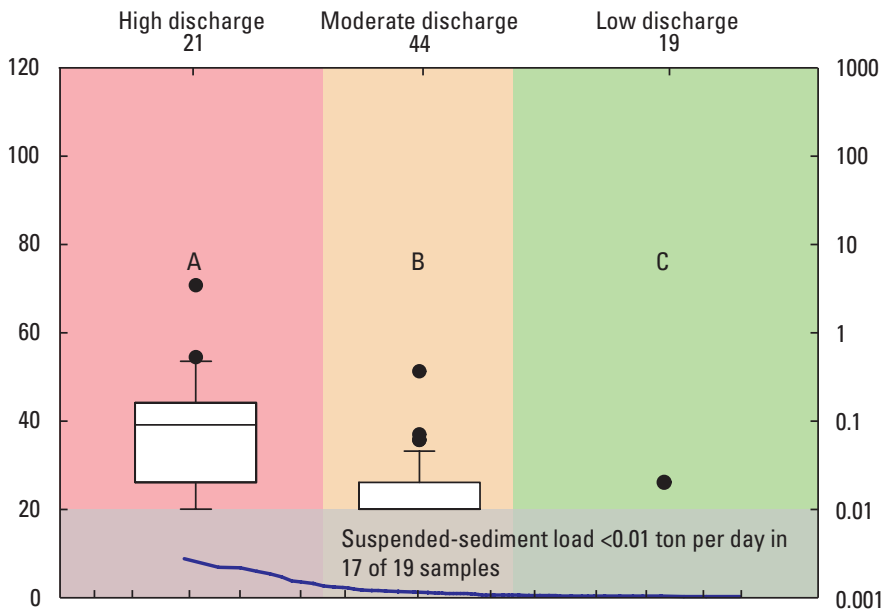

\section{EXPLANATION}

27 Number of values

I

T 90th percentile

75 th percentile

Median

25th percentile

$\perp$ 10th percentile

- Outlier

A Similar letters indicate similar datasets, whereas differing letters indicate a statistical difference between datasets

- Site specific discharge 2004-07 and 2010-16

B. Site 2

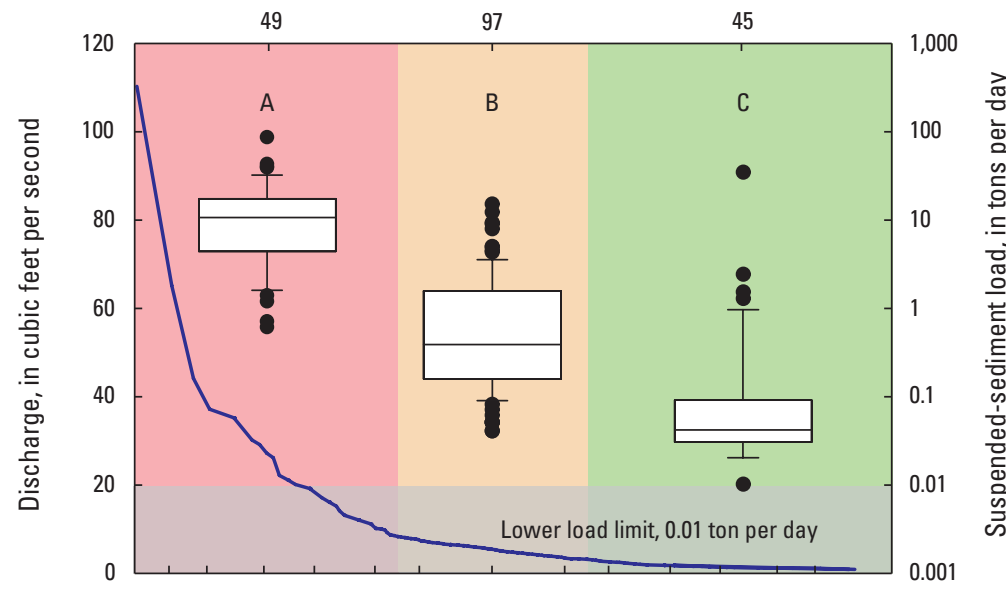

\section{Site 3}

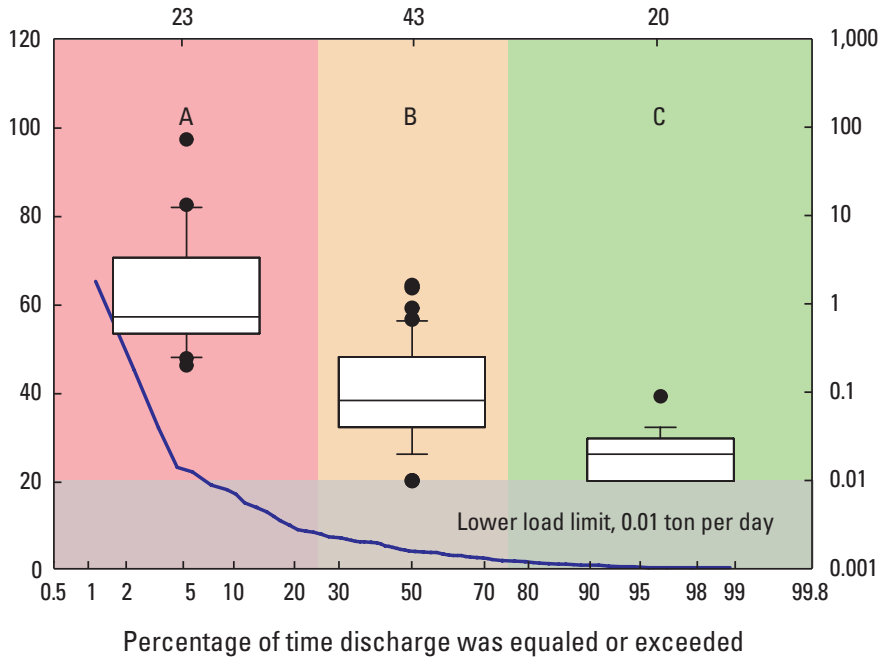

Figure 15. Suspended-sediment loads measured under specified ranges of discharge at $(A)$ site 1, $(B)$ site 2, and $(C)$ site 3, Clear Creek, western Nevada, water years 2004-07 and 2010-16. The flow duration curve was plotted using only those discharge measurements associated with a suspended-sediment sample. 


\section{Bedload Sediment}

Bedload, which is the material rolling or bouncing along the bed of the stream, is highly variable and difficult to collect. Generally, bedload only occurs when a threshold discharge in the creek is exceeded, providing sufficient energy to dislodge material from the streambed. The threshold discharge can vary from site to site because of streambed characteristics such as grade and bed-material size/weight. Discharge during this study was usually less than the long-term mean discharge (fig. 5), and bedload transport was rarely observed; however, bedload transport may have occurred between site visits. No bedload transport was observed during any field visits at site 1 during the current study, and indications are that bedload movement was rare. During a high discharge event in the lower basin on February 9, 2014, bedload was observed moving in the channel at both sites 2 and 3 when discharges reached 35 and $45 \mathrm{ft}^{3} / \mathrm{s}$, respectively (second-highest discharge on record at site 3 ). Bedload transport on that day was 7.0 ton/d at site 2 and 1.2 ton/d farther downstream at site 3 (table 7), indicating nearly 6 ton/d was deposited between the two sites during this event. Although movement of bed sediment was observed and collected four subsequent times at site 2, the sample of bedload collected on February 9, 2014 was the only time bedload was observed at site 3 during this study (table 7). Due to changes in gradient, stream velocities, and energy between sites 2 and 3, deposition of bed sediment was likely occurring between sites 2 and 3 when bedload was measured at site 2 and subsequently not observed at site 3 . Total measured range in bedload at site 2 was $0.12-7.0$ ton/d, with $3.3 \mathrm{ft}^{3} / \mathrm{s}$ identified as the threshold discharge supporting bedload transport. Change in the bedload threshold discharge over time also indicates whether the quantity of bed material that has accumulated in the stream channel is increasing or decreasing which is a useful indicator for whether sediment mitigation measures are reducing the source of bedload material. Total bedload deposition between sites 2 and 3 was estimated to range from 0.12 to 5.8 ton/d when bedload movement was observed and measured at site 2 .

Table 7. Bedload-sediment data for samples collected at sites along Clear Creek, water years 2013-16.

[U.S. Geological Survey site Nos. given in parentheses after the site name. Date: Month-day-year. Time: 24-hour clock. Sand-sized bedload fraction: Greater than 0.0625 millimeter and less than or equal to 2 millimeters in diameter. Gravel-sized bedload fraction: With a diameter greater than $2 \mathrm{~mm}$. Abbreviations: $\mathrm{ft}^{3} / \mathrm{s}$, cubic feet per second; ton/d, ton per day; -, data not available]

\begin{tabular}{|c|c|c|c|c|c|c|}
\hline Date & Time & $\begin{array}{c}\text { Discharge } \\
\left(\mathrm{ft}^{3} / \mathrm{s}\right)\end{array}$ & $\begin{array}{l}\text { Bedload } \\
\text { sediment, total } \\
\text { sample mass, } \\
\text { dry weight } \\
\text { (grams) }\end{array}$ & $\begin{array}{c}\text { Sand-sized } \\
\text { bedload } \\
\text { fraction }\end{array}$ & $\begin{array}{l}\text { Gravel-sized } \\
\text { bedload } \\
\text { fraction }\end{array}$ & $\begin{array}{c}\text { Bedload } \\
\text { sediment } \\
\text { transport rate } \\
\text { (ton/d) }\end{array}$ \\
\hline \multicolumn{7}{|c|}{ Site 1: Clear Creek above Highway 50, near Spooner Summit, Nevada (10310485) } \\
\hline- & - & - & - & - & - & - \\
\hline \multicolumn{7}{|c|}{ Site 2: Clear Creek near Carson City, Nevada (10310500) } \\
\hline $02-09-14$ & 0840 & 35 & 307 & 267.1 & 39.9 & 7.0 \\
\hline 02-12-14 & 1330 & 6.4 & 7.0 & 6.2 & 0.77 & 0.12 \\
\hline 03-06-14 & 1331 & 7.2 & 74.1 & 63.0 & 11.1 & 1.3 \\
\hline $05-22-14$ & 1132 & 3.3 & 55.6 & 46.1 & 9.5 & 0.71 \\
\hline $12-21-15$ & 1420 & 11 & 60.4 & 48.3 & 12.1 & 0.77 \\
\hline \multicolumn{7}{|c|}{ Site 3: Clear Creek at Fuji Park, at Carson City, Nevada (10310518) } \\
\hline 02-09-14 & 1300 & 45 & 25.7 & 23.6 & 2.1 & 1.2 \\
\hline $02-12-14$ & 1300 & 6.3 & 0 & - & - & - \\
\hline 03-06-14 & 1330 & 8.4 & 0 & - & - & - \\
\hline $05-22-14$ & 1430 & 2.7 & 0 & - & - & - \\
\hline
\end{tabular}


The relation between bedload and discharge for all samples collected during 2013-16 at site 2 (fig. 16) was done using the same logarithm transformation method as with suspended sediment and discharge. A very small bias correction factor (smear) of 0.01 was applied during retransformation of the data out of log space. During this study, this analysis was not possible for sites 1 and 3 because bedload was not observed at site 1 and was observed once at site 3 . The coefficient of determination $\left(\mathrm{R}^{2}\right)$ obtained for the relation between streamflow and bedload for each period of study demonstrates that generally flow accounts for the majority of the variability observed in bedload (2004-07 dataset $\mathrm{R}^{2}=0.62,2010-12$, dataset $R^{2}=0.66$, and 2013-16 dataset $R^{2}=0.50$; fig. 18). The lower coefficient of determination for the current study may be due largely to the limited dataset and lower flows encountered during the 2013-16 period (fig. 5).
The scatter observed in the data is not unexpected given the variation in precipitation, snowmelt, channel stability, source material (local geology), and other local runoff characteristics contributing to bedload movement and discharge during each sampling event. Although bedload for a given discharge during the 2010-12 interim study was lower than the baseline 2004-07 study and the five bedload samples added to the dataset during the current study appear lower for a given discharge, there is no significant change in bedloads in the current dataset. However, these comparisons are made using limited data and there are insufficient data collected from similar discharges to perform a proper analysis. Since NDOT erosion mitigation work has been ongoing during this study, continued data collection is suggested to help strengthen the relation between bedload and discharge for use in future analyses.

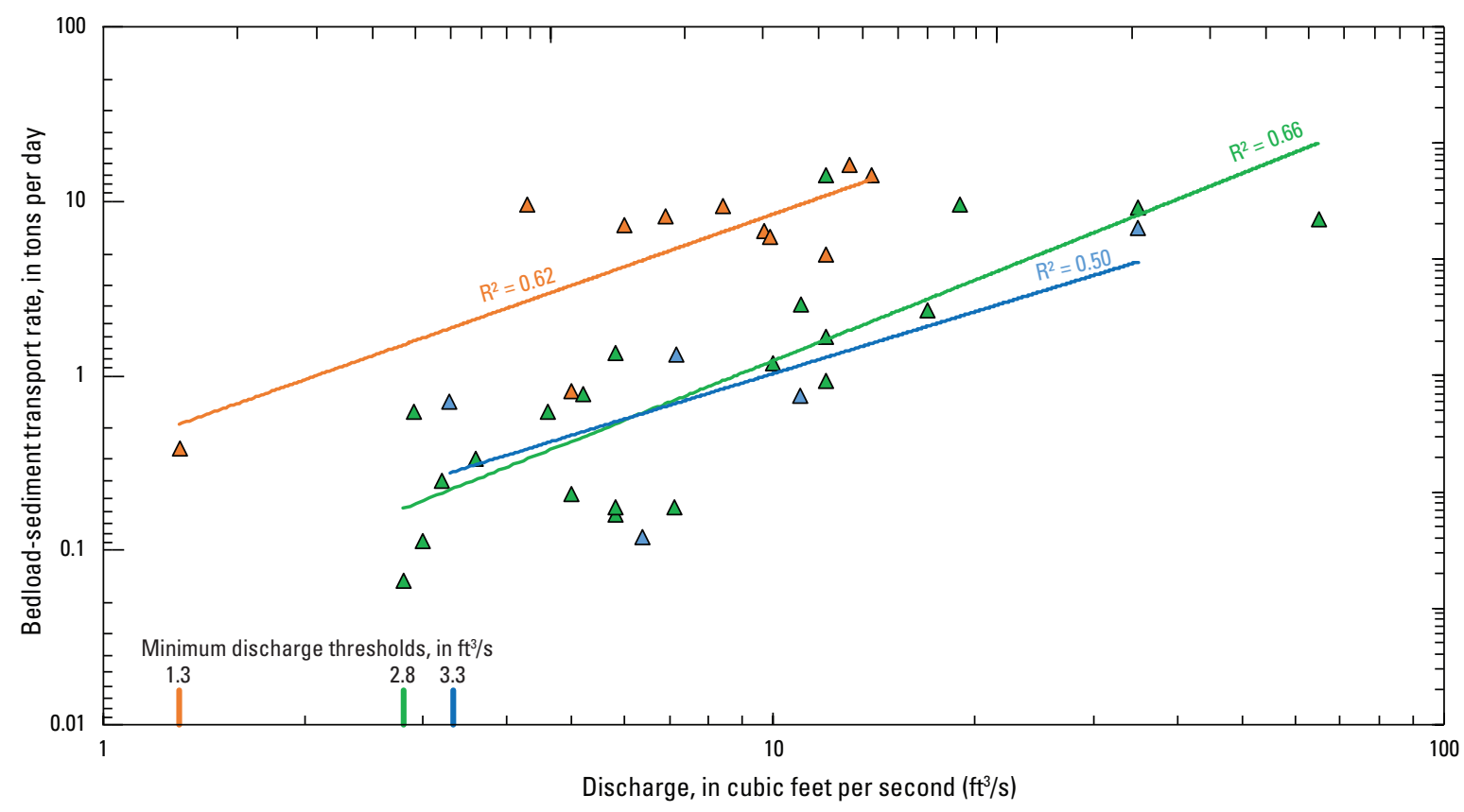

EXPLANATION

$\Delta \quad$ Water years 2004-07

- Water years 2004-07; rate $=10^{\wedge}\left(1.36^{*} \log \left[\right.\right.$ discharge]-0.52), $R^{2}=0.62$

$\Delta \quad$ Water years 2010-12

— Water years 2010-12; rate $=10^{\wedge}\left(1.56^{*} \log [\right.$ discharge $\left.]-0.93\right), R^{2}=0.66$

$\Delta \quad$ Water years 2013-16

- Water years 2013-16; rate $=10^{\wedge}\left(1.18^{*} \log \left[\right.\right.$ discharge]-1.18), $R^{2}=0.50$

Figure 16. Relation between bedload and discharge at site 2, Clear Creek, western Nevada, water years 2004-07, 2010-12, and 2013-16. 
Bedload particle-size analyses (weight fractions) were done on all bedload samples collected from Clear Creek (table 7). The particle-size distributions were used to determine the percent contribution of silt, sand, and gravel to the composition of each bedload sample collected at sites 2 and 3 (fig. 17). Sand-sized sediment is categorized as particles greater than $0.0625 \mathrm{~mm}$ and less than or equal to $2 \mathrm{~mm}$ in diameter, whereas gravel-sized sediments are particles with a diameter greater than $2 \mathrm{~mm}$. Bedload sample composition from site 2 in 2013-16 was composed of mostly sand-sized sediment with some gravel (fig. 17). Huntington and others (2015) noted that gravel-sized sediment contributed to the bedload composition only when discharge equaled or exceeded $2.8 \mathrm{ft}^{3} / \mathrm{s}$. However, for the current study, the minimum discharge bedload transport was observed at was $3.3 \mathrm{ft}^{3} / \mathrm{s}$ supporting a threshold of around $3 \mathrm{ft}^{3} / \mathrm{s}$ for bedload transport at site 2. Although the gravel fraction of the total bedload composition was small compared with sand and varied greatly, some gravel was present in all bedload samples (table 7). Bedload composition from the high discharge sample at site 3 in 2014 was composed of dominantly sand-sized sediment with about 8 percent gravel. Bedload deposition between sites 1 and 2 was composed of about 0.8 tons of gravel and 5 tons of sand.

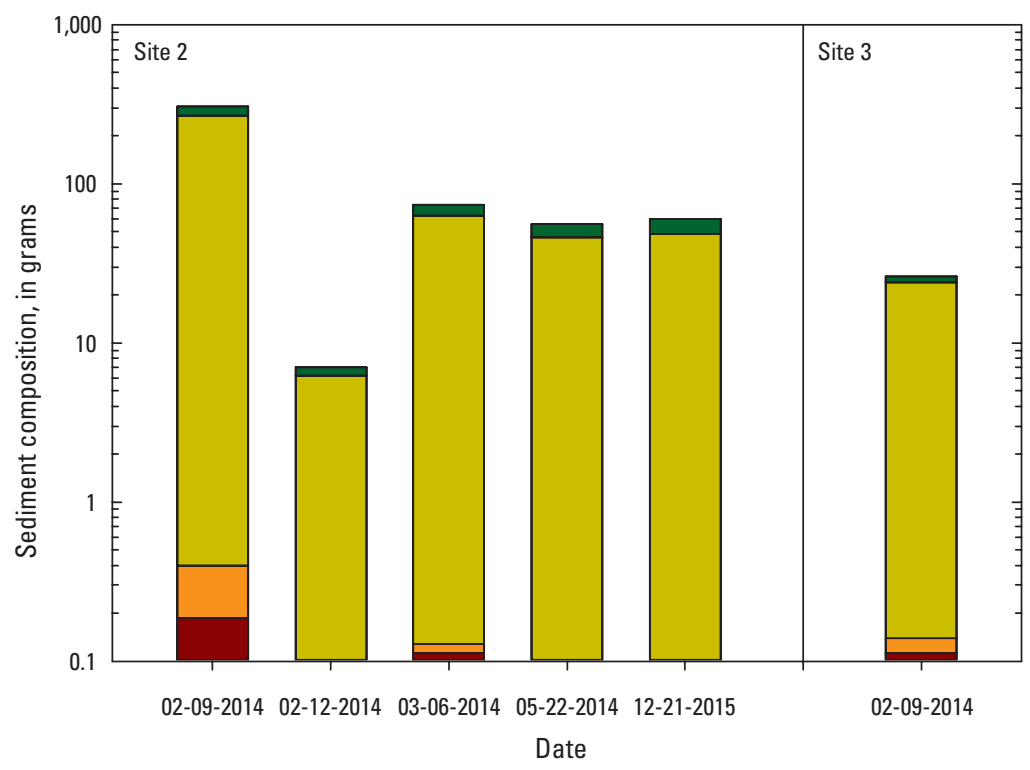

No suspended sediment particle size analysis available for 02-12-2014 and 12-21-2015

\section{EXPLANATION}

Load composition, in grams

Suspended sediment silt

Suspended sediment sand

Bedload sand

Bedload gravel

Figure 17. Sediment composition and associated discharge at Clear Creek site 2 (U.S. Geological Survey streamgage 10310500; Clear Creek near Carson City, Nevada) and 3 (U.S. Geological Survey site 10310518; Clear Creek at Fuji Park, at Carson City Nevada), western Nevada, water years 2013-16. 


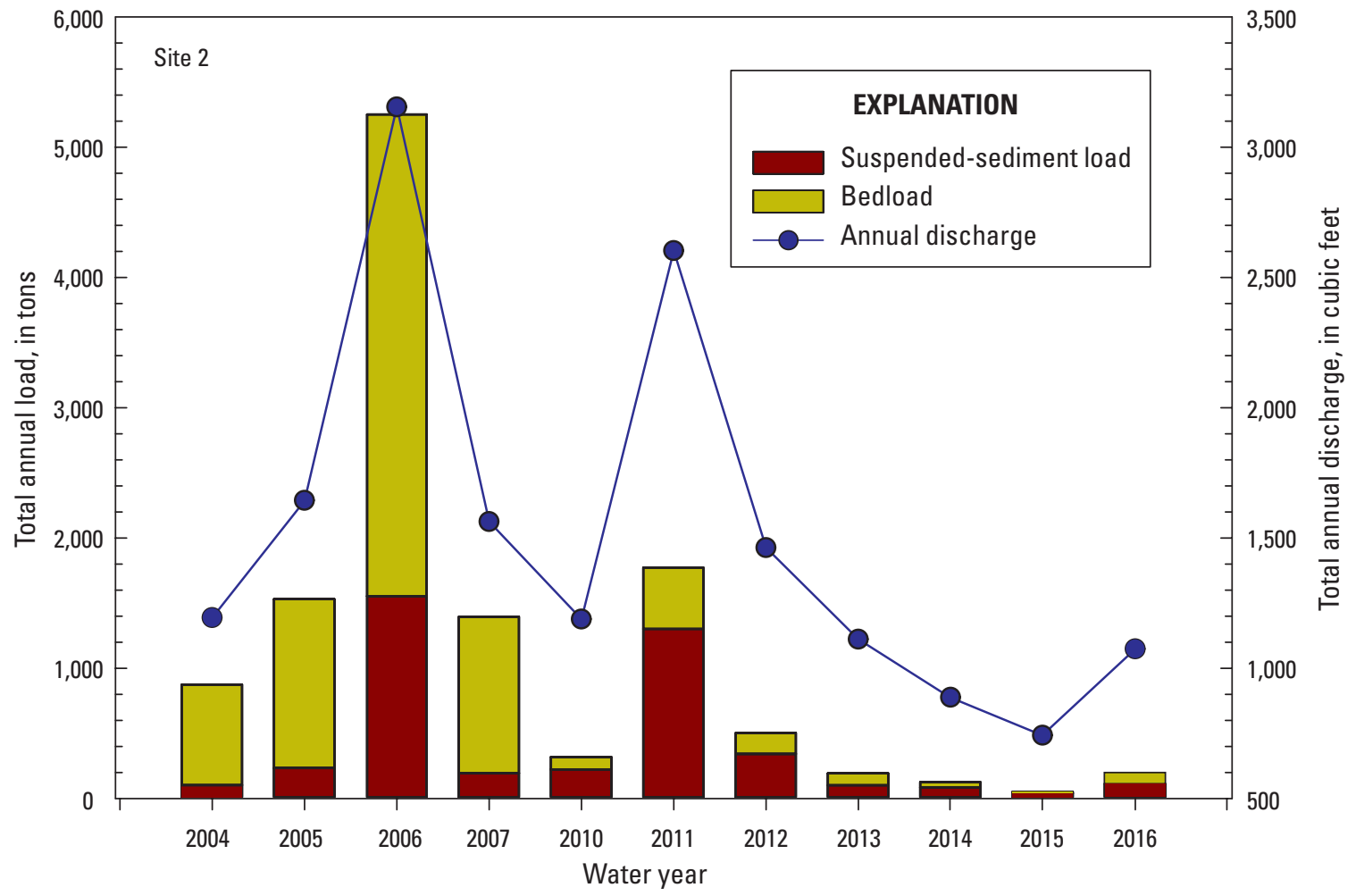

Figure 18. Annual Clear Creek total sediment load and discharge for site 2 (U.S. Geological Survey streamgage 10310500; Clear Creek near Carson City, Nevada), western Nevada, 2004-07 and 2010-16.

\section{Total Sediment Loads}

Total annual sediment load, which is the sum of annual suspended-sediment load and annual bedload, was computed at site 2 during $2013-16$ and compared to loads from the 2004-07 and 2010-12 studies (table 8). Annual suspended-sediment loads and bedloads were computed for site 2 using daily discharge from the site 2 streamgage and the relation between discharge and suspended-sediment load and bedload shown in figures $14 B$ and 16 . Because the autosampler was unavailable during previous studies for use in evaluating the relation between suspended sediment and discharge, and subsequently the estimation of annual suspended-sediment loads, annual loads were likely biased low. Therefore, to remove the influence of potential bias from the comparisons made among the three periods of study, the autosampler data were not included in the comparative assessment here; although, it is acknowledged these overall loads being compared are lower than actual loads. However, should data collection continue at site 2 , the autosampler data that represents suspended sediment during storm conditions could be used to compare to 2013-16 data. The difference between estimated total annual sediment load with and without autosampler data is shown in table 8. Annual bedload for the 2004-07 and 2010-12 studies shown in table 8 differs from what was reported by Huntington and Savard (2015; table 5) because the calculated daily bedloads were not adjusted for minimum flow thresholds; therefore, those reported here are between 6 and 35 percent less than previously reported. Total sediment loads are a function of stream discharge and sediment supply and therefore vary greatly from year to year with discharge (fig. 18). Total annual sediment loads during the full study period have ranged from $50 \mathrm{t} / \mathrm{yr}$ in 2015 to $5,300 \mathrm{t} / \mathrm{yr}$ in 2006 (table 8). The three study periods were not significantly different from one period to the next.

Bedload at site 2 represented $70-89$ percent of the total sediment load in 2004-07, 27-32 percent of total sediment load in 2010-12, and 7-21 percent in 2013-16 (when calculated using total sediment load with discrete and autosampler data), which is mainly a result of the climatic conditions during these three periods and a reduction in flows during each of the successive periods. Mean daily discharge was significantly lower in 2010-12 than in 2004-07 ( $\mathrm{p}=0.026$ ) and also significantly lower in 2013-16 than in 2010-12 $(\mathrm{p}<0.001)$ and was the principle reason for the decrease in bedload that results in decreased total sediment load over time.

An estimate of total sediment yield was calculated for site 2 to normalize the total load of sediment transported in Clear Creek to contributing drainage area (table 8). The drainage basin contributing to site 2 is $15.4 \mathrm{mi}^{2}$ (table 1 ), 
Table 8. Reported mean and total annual discharge, estimated annual suspended-sediment loads, annual bedload, total sediment load, and total sediment yield for site 2 (U.S. Geological Survey streamgage 10310500; Clear Creek near Carson City, Nevada).

[Calculating annual suspended sediment load without autosampler data (which are typically higher sediment loads during storm conditions) inherently underestimates the annual load. However, it order to compare to previous studies, annual loads were computed using load relations with discrete data only. Data from water years 2004-07 from Seiler and Wood (2009); data from water years 2010-12 from Huntington and Savard (2015). Abbreviations: $\mathrm{ft}^{3}$, cubic feet; $\mathrm{ft}^{3} / \mathrm{s}$, cubic feet per second; acre-ft, acre feet; $\left[\left(\right.\right.$ ton $\left.\left./ \mathrm{mi}^{2}\right) / \mathrm{yr}\right]$, tons per square mile per year; NA, not applicable]

\begin{tabular}{|c|c|c|c|c|c|c|c|c|c|}
\hline \multirow[b]{2}{*}{$\begin{array}{c}\text { Water } \\
\text { year }\end{array}$} & \multicolumn{8}{|c|}{ Annual } & \multirow[b]{2}{*}{$\begin{array}{c}\text { Average } \\
\text { annual total } \\
\text { sediment } \\
\text { yield } \\
{\left[\left(\text { ton } / \mathrm{mi}^{2}\right) / \mathrm{yr}\right]}\end{array}$} \\
\hline & $\begin{array}{c}\text { Mean } \\
\text { discharge } \\
\left(\mathrm{ft}^{3} / \mathrm{s}\right)\end{array}$ & $\begin{array}{c}\text { Total } \\
\text { discharge } \\
\text { (acre-ft) }\end{array}$ & $\begin{array}{l}\text { Suspended } \\
\text { sediment load } \\
\text { with discrete } \\
\text { data only } \\
\text { (tons) }\end{array}$ & $\begin{array}{l}\text { Suspended } \\
\text { sediment } \\
\text { load with } \\
\text { discrete and } \\
\text { autosampler } \\
\text { data }\end{array}$ & Bedload & $\begin{array}{c}\text { Total } \\
\text { sediment } \\
\text { load with } \\
\text { discrete data } \\
\text { only }\end{array}$ & $\begin{array}{c}\text { Total } \\
\text { sediment } \\
\text { load with } \\
\text { discrete and } \\
\text { autosampler } \\
\text { data }\end{array}$ & $\begin{array}{c}\text { Total } \\
\text { sediment load } \\
\text { underestimate } \\
\text { (percent) }\end{array}$ & \\
\hline \multicolumn{10}{|c|}{ Baseline study } \\
\hline 2004 & 3.26 & 3,260 & 100 & NA & 770 & 870 & NA & NA & 56 \\
\hline 2005 & 4.50 & 2,370 & 230 & NA & 1,300 & 1,500 & NA & NA & 97 \\
\hline 2006 & 8.64 & 6,260 & 1,550 & NA & 3,700 & 5,300 & NA & NA & 344 \\
\hline 2007 & 4.28 & 3,100 & 190 & NA & 1,200 & 1,400 & NA & NA & 91 \\
\hline \multicolumn{10}{|c|}{ Interim study } \\
\hline \multicolumn{10}{|c|}{ Current study } \\
\hline 2013 & 3.04 & 2,200 & 100 & 330 & 90 & 190 & 420 & 55 & 12 \\
\hline 2014 & 2.43 & 1,800 & 85 & 270 & 40 & 125 & 310 & 60 & 8 \\
\hline 2015 & 2.03 & 1,500 & 40 & 140 & 10 & 50 & 150 & 67 & 3 \\
\hline 2016 & 2.94 & 2,100 & 110 & 340 & 90 & 200 & 430 & 53 & 13 \\
\hline
\end{tabular}

including the $2.4 \mathrm{mi}^{2}$ upstream drainage basin area contributing to site 1 . Average annual total sediment yield at site 2 ranged from 56 to 344 (ton/ $\left.\mathrm{mi}^{2}\right) / \mathrm{yr}$ during 2004-07, from 21 to $115\left(\right.$ ton $\left./ \mathrm{mi}^{2}\right) / y r$ during 2010-12, and from 3 to 13 (ton/ $\left.\mathrm{mi}^{2}\right) /$ yr during 2013-16 (table 8).

\section{Water-Quality Characteristics}

Clear Creek water samples were collected and analyzed for selected major inorganic ions, trace metals, and nutrients, at least four times per WY during 2013-16 (table 9), for the purposes of characterizing changes in water chemistry in Clear Creek over time. With the exception of the two samples collected in July 2014 and 2015 from site 2, all water-quality samples were collected at each site on the same day in order to characterize Clear Creek water quality with distance downstream.

Seiler and Wood (2009) found the Clear Creek water to be a dilute calcium/sodium bicarbonate with low nutrient concentrations, and the 2013-16 dataset continues to represent this same water type (table 9 and fig. 19). Generally, cations are dominated by calcium in autumn but show a slightly increasing sodium character during winter and spring; anions are dominated by bicarbonate in autumn but shift towards a more sodium chloride dominated chemistry in winter and spring (November-March) (fig. 19) at sites 2 and 3. Seiler and Wood (2009) suggested the larger contributing area to the lower Clear Creek reaches, geology, and seasonal application of road salt to adjacent roads was contributing to the dissolved salt loads. Road salt used by NDOT consists of a sodium chloride brine and sand (Eric Young, Nevada Department of Transportation, written commun., February 23, 2014).

Field measurements of water temperature, $\mathrm{pH}$, and specific conductance were made at the three Clear Creek sites with each water-quality sample collection and with most suspended-sediment samples (table 9); therefore, field measurements were monitored more frequently than other water-quality constituents. During this study, temperatures throughout Clear Creek ranged from 0.1 to $19.7^{\circ} \mathrm{C}$, and $\mathrm{pH}$ ranged from 7.0 to 8.6 , similar to the observed ranges during the 2004-07 and 2010-12 studies. Temperature and $\mathrm{pH}$ increased with distance downstream. 


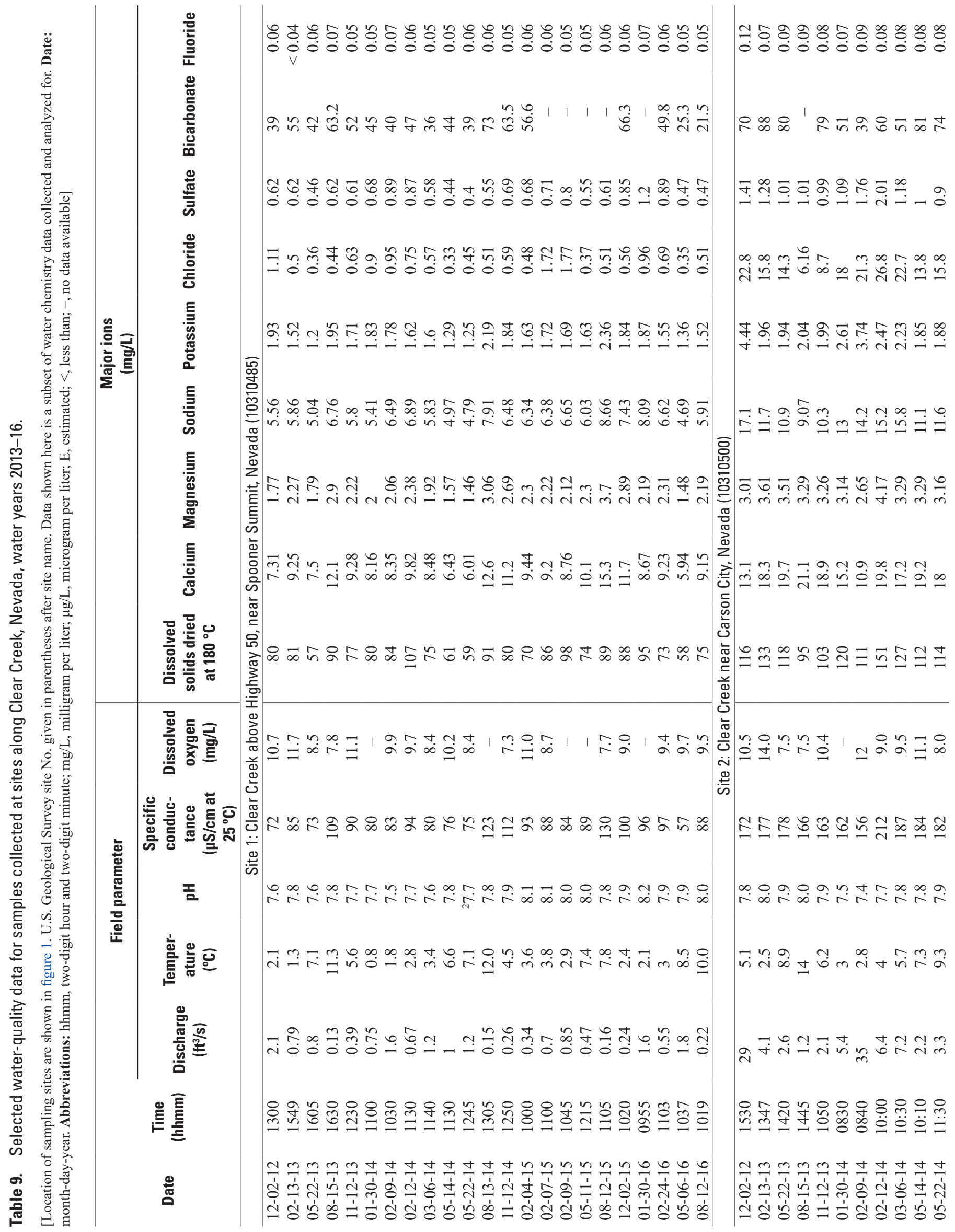




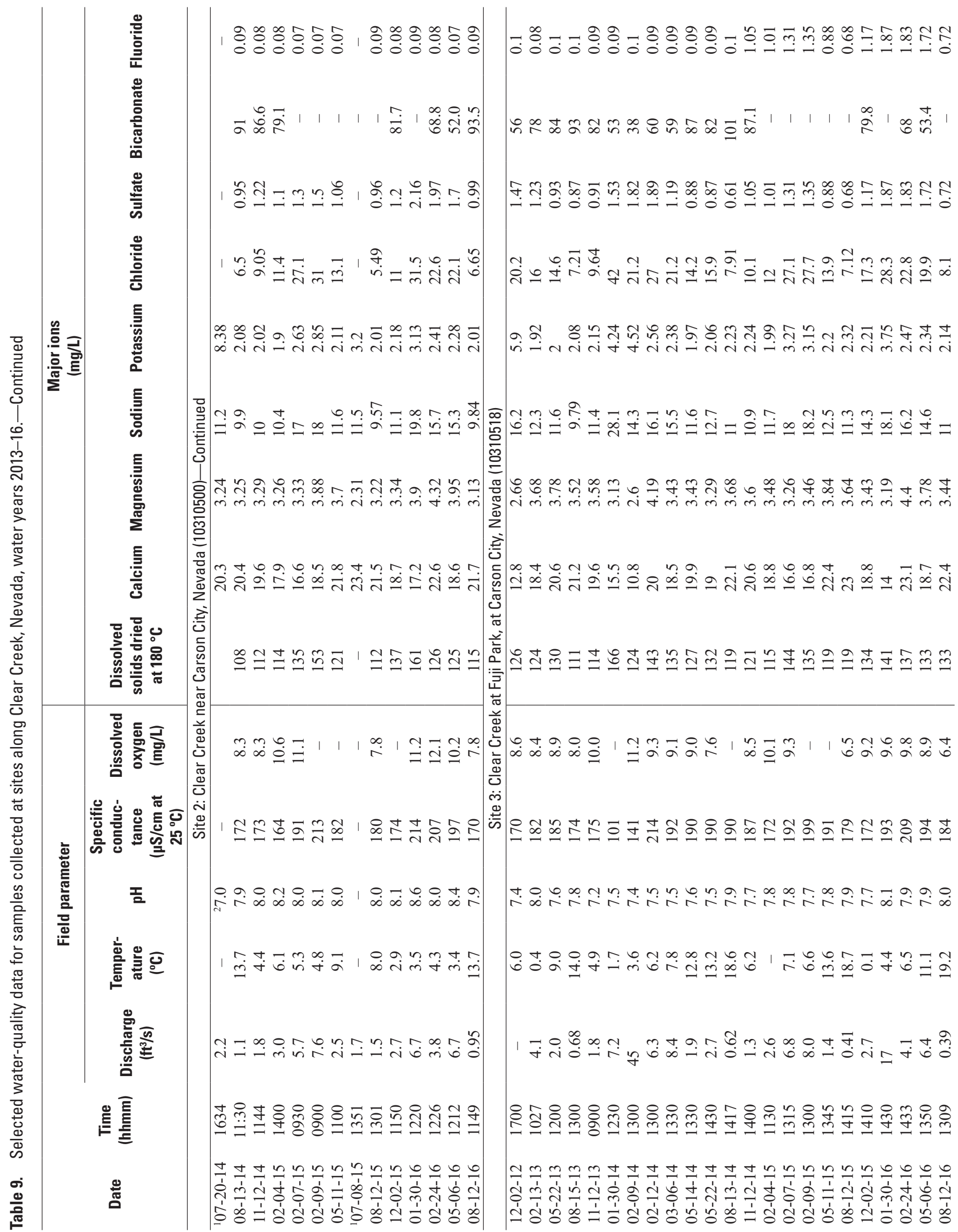




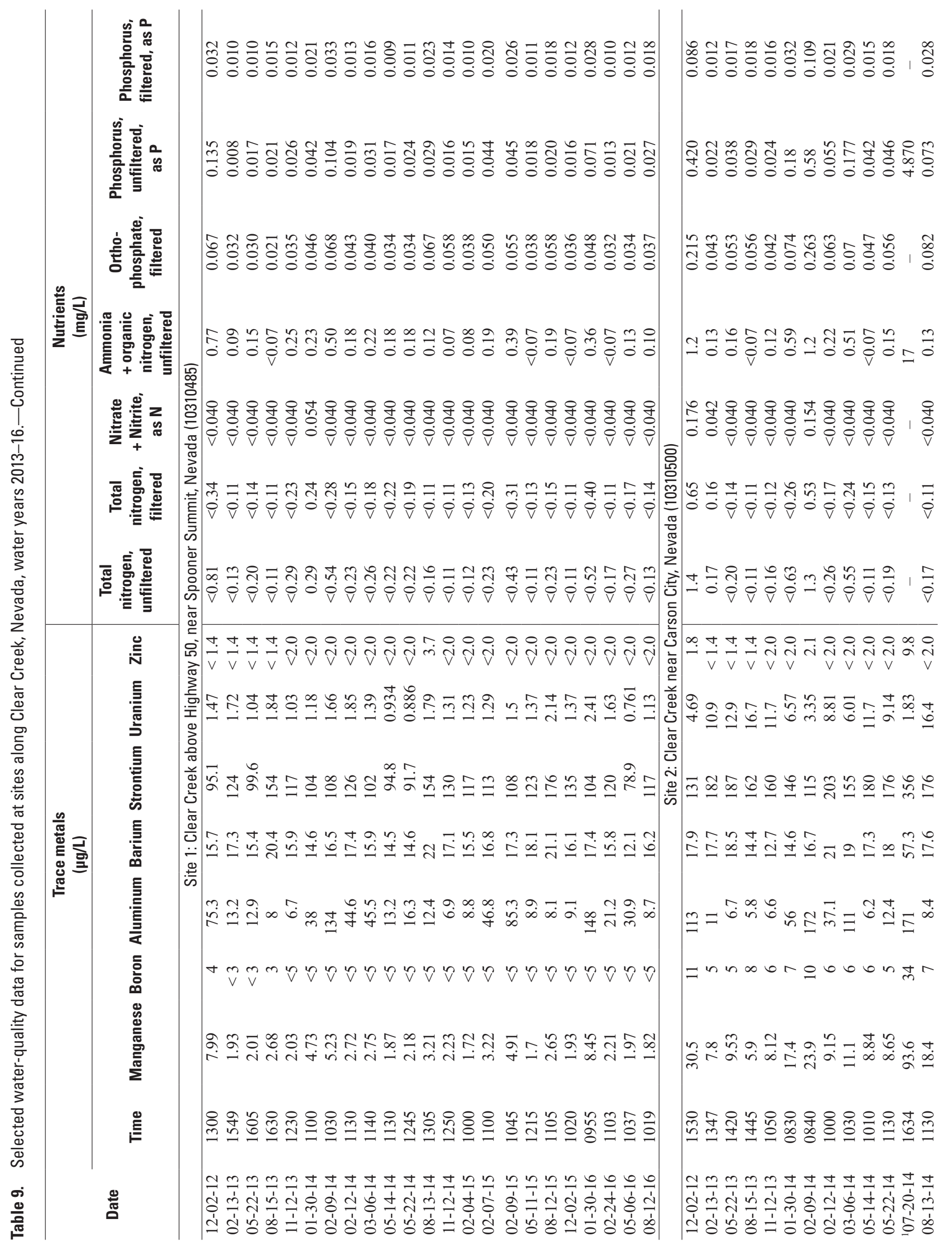




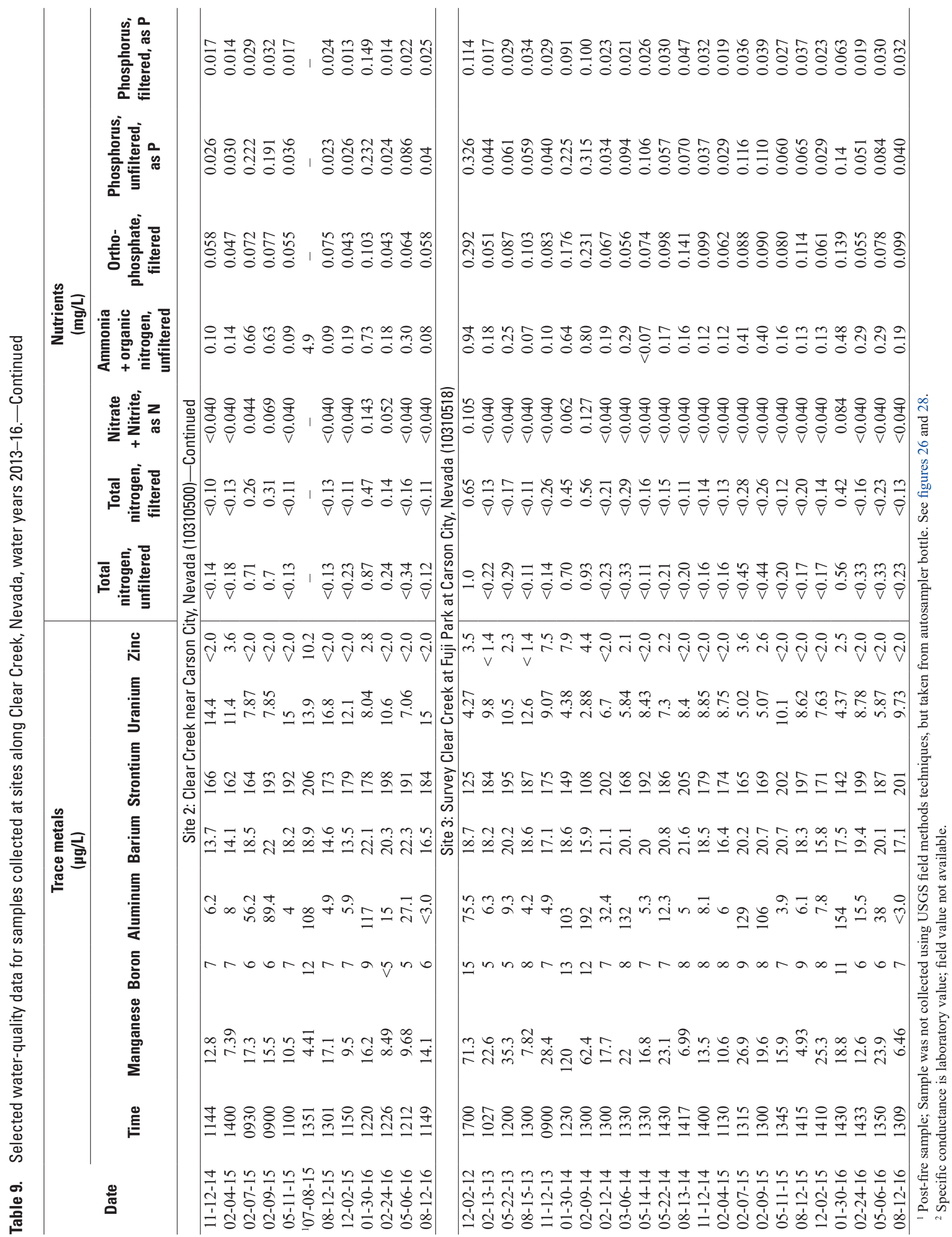




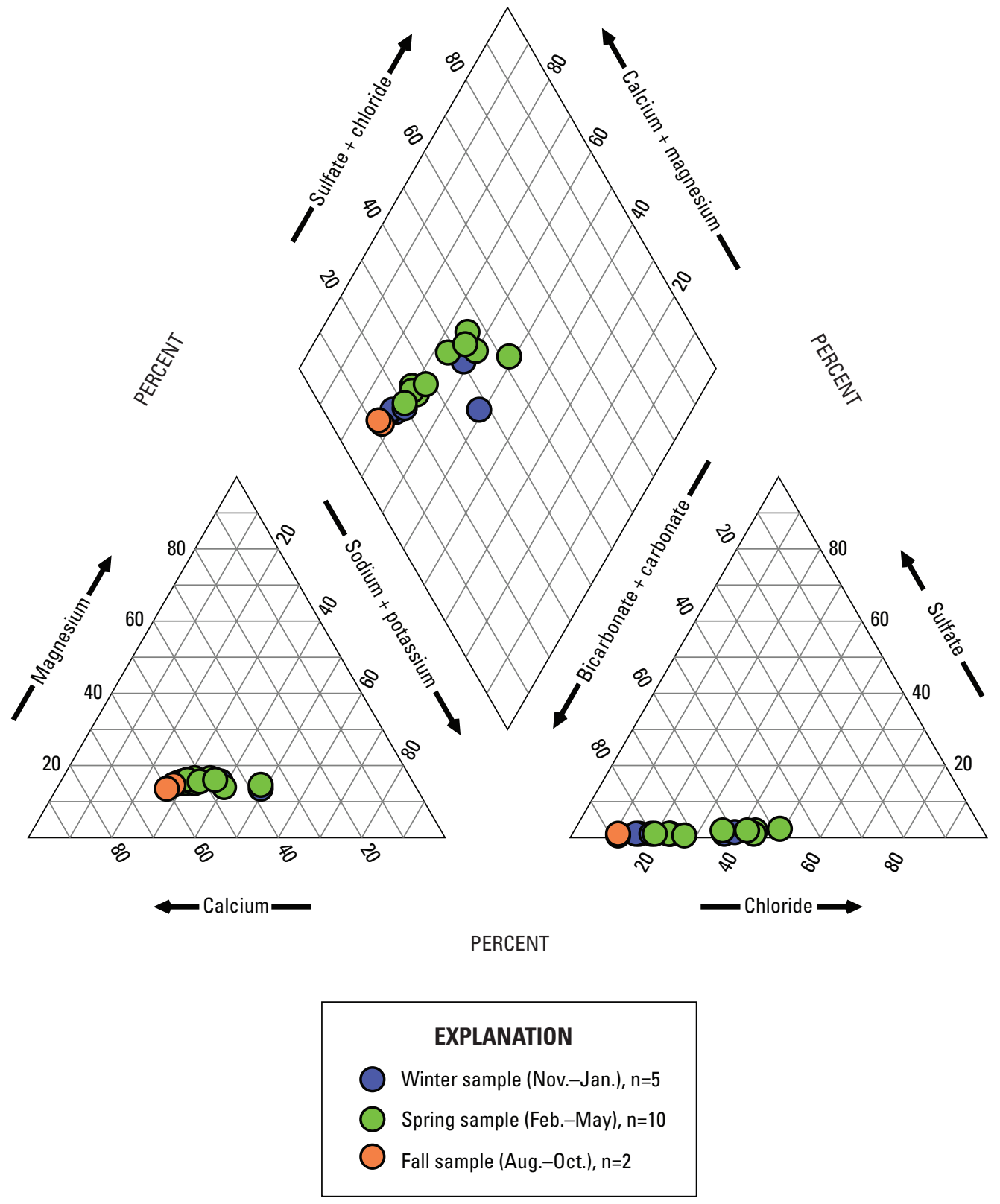

Figure 19. Water type in Clear Creek, site 2 (U.S. Geological Survey streamgage 10310500; Clear Creek near Carson City, Nevada), western Nevada. 
The specific conductance of water is a measure of water's capacity to conduct electrical current, is a method of measuring the ionic content of a sample, and is a general indicator of water salinity. For most waters, the primary major inorganic ions that contribute to specific conductance include calcium, magnesium, sodium, potassium, carbonate, chloride, and sulfate. Specific-conductance measurements in Clear Creek ranged from 57 to $214 \mu \mathrm{S} / \mathrm{cm}$ at $25^{\circ} \mathrm{C}$ during 2013-16 (table 9) and from 40 to $255 \mu \mathrm{S} / \mathrm{cm}$ at $25^{\circ} \mathrm{C}$ during the period of record (fig. 20A). Median specific conductance at site 1 is lower than at sites 2 and $3(p<0.001)$. There was no significant difference in median specific conductance measurements between sites 2 and 3 ( $\mathrm{p}=0.061$; fig. 20A). A comparison of specific conductance measurements from each period of study (2004-07, 2010-12, and 2013-16) showed that, although there was no significant difference between the 2004-07 and 2010-12 studies, there was a significant increase in specific conductance between the 2010-12 and 2013-16 dataset at all three sites (fig. 20B-D).

At site 1, specific conductance was lower at higher discharge (fig. 21A), which is to be expected in natural drainage basins where increased runoff tends to dilute salt concentrations (Hem, 1985). The steeper trend line slope associated with the 2013-16 dataset (fig. 21A) is similar to that of the 2004-07 dataset, which suggests that discharge during these periods had a greater influence on specific conductance than during 2010-12 and is likely due to discharges being lower during this study period than during previous study periods. Concentrations of major ions (cations) generally increased throughout the study periods as indicated by the positive slopes in figures $22 A-B$. Several chloride spikes $(\mathrm{n}=3)$ in February 2015 (fig. 22B) can likely be attributed to the first winter storm of the season when road salts were washed from the highway.

Specific conductance in samples collected from sites 2 and 3 did not appear to have as much relation to discharge as was observed for site 1 (fig. $21 B-C$ ). This lack of relation with discharge at site 3 suggests a steady supply of salts in the lower reaches of Clear Creek that are not necessarily sensitive to streamflow. Similar to site 1, concentrations of major ions at site 2 and 3 generally increased throughout the study periods, as indicated by the positive slopes in figures $22 C-F$. However, due to the significant decrease in discharge through time, no other conclusions as to why all these ion concentrations are increasing can be explored until data collection during periods of higher discharges occur.

Many increased concentrations of aluminum have been measured at all three Clear Creek sampling sites, though only since December 2012 (fig. 23). Generally higher concentrations were measured during increased discharge events and typically coincided with winter storms. Since these episodic aluminum spikes were also observed at the reference site (site 1) located upstream of Highway 50, this suggests the aluminum spikes are naturally occurring and not likely related to highway storm-runoff. Increased concentrations of aluminum could be attributed to increased erosion of source material (Sierra Nevada granitic rocks; Dodge and others, 1968) during higher flows.

\section{Bed-Sediment and Semi-Permeable Membrane Device Polynuclear Aromatic Hydrocarbons}

Concentrations of the 28 PAHS measured in the bed-sediment sample collected in September 2014 were less than the long-term method detection limit of $5 \mu \mathrm{g} / \mathrm{kg}$ (U.S. Geological Survey, 2018). The laboratory analysis of the SPMD sample extracts obtained as part of this study included the same 28 PAH compounds analyzed in the bed-sediment sample. The following data evaluation focuses on selected PAHs that have been cited in the literature as being associated with used motor oil (National Research Council, 1983) and where concentrations in environmental SPMD extracts were greater than the quantifiable level of $100 \mathrm{ng} /$ ampoule (table 10).

Each environmental PAH concentration in SPMD extracts were evaluated with respect to its quantifiable limit, percent recovery, and dialysis and field blanks (table 10; fig. 24). Concentrations in each composited SPMD sample were normalized to the number of membranes extracted prior to comparing concentrations among environmental and blank samples. Of the PAHs that have been commonly associated with used motor oil, fluoranthene, 1-methylphenanthrene, naphthalene, phenanthrene, and pyrene were measured in environmental samples at concentrations exceeding the quantification level (100 ng/ampoule). Normalized concentrations of these five PAH compounds were similar to concentrations found in both dialysis and field blank samples (fig. 24). Although these PAHs were measured in some SPMD environmental samples, given that concentrations were similar to or less than dialysis and field blank concentrations, it is likely that these measurements are a result of contamination from the atmosphere at the sampling site, transport, and (or) the handling and processing, rather than aqueous conditions in Clear Creek during the periods of deployment. Therefore, the data indicate used motor oil was not detected in Clear Creek during the times of SPMD deployment. 
A. Period of record, 2004-16

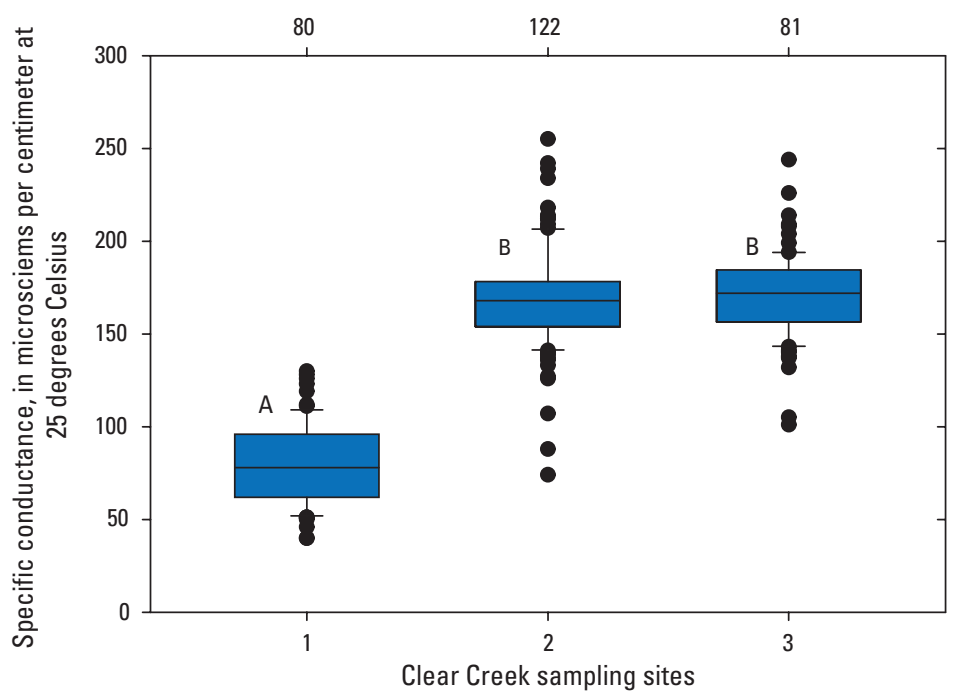

EXPLANATION
Water years 2004-07

Water years 2010-12

Water years 2013-16

$\perp$ 10th percentile

- Outlier

A Median concentrations that are significantly different from each other are represented by different letters
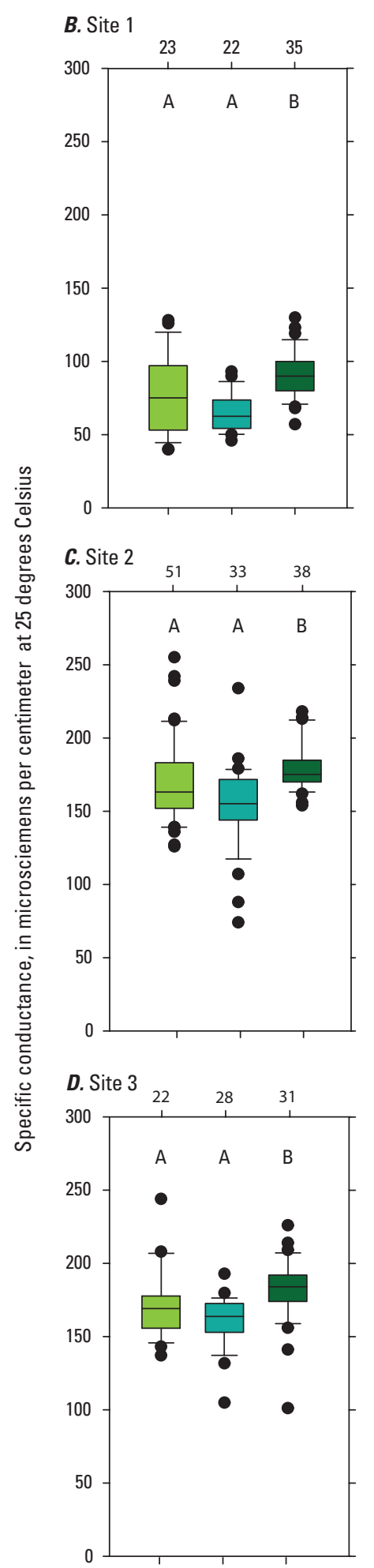

Study periods

Figure 20. Distribution of specific conductance during $(A)$ period of record at all three Clear Creek sites, 2004-07 and 2010-16, and separated by study periods of 2004-07, 2010-12, and 2013-16 at (B) site 1 (U.S. Geological Survey reference site 10310485; Clear Creek above Highway 50, near Spooner Summit, Nevada), (C) site 2 (U.S. Geological Survey streamgage 10310500; Clear Creek near Carson City, Nevada), and (D) site 3 (U.S. Geological Survey reference site 10310518; Clear Creek at Fuji Park, at Carson City, Nevada) on Clear Creek, western Nevada. 

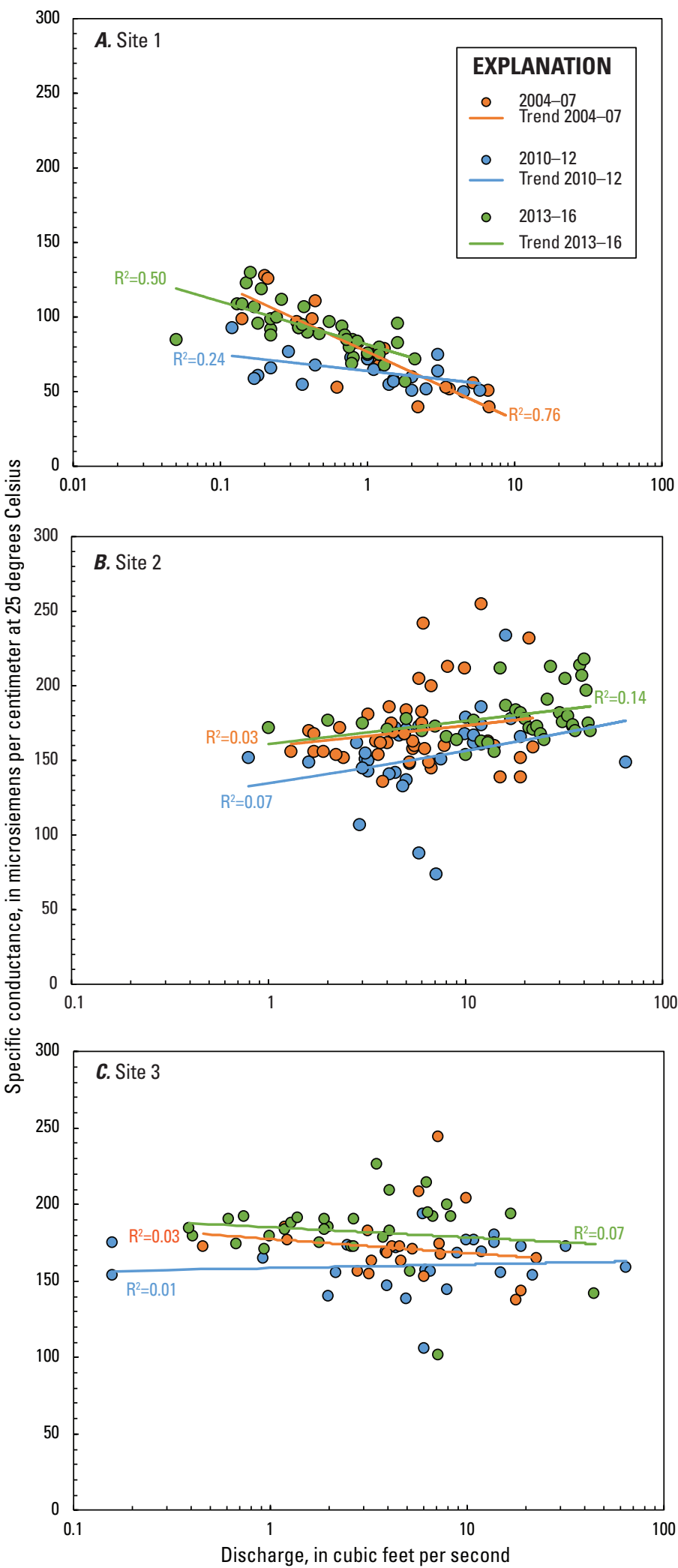

Figure 21. Relation between discharge and specific conductance at $(A)$ site 1 (U.S. Geological Survey reference site 10310485; Clear Creek above Highway 50 near Spooner Summit, Nevada), (B) site 2 (U.S. Geological Survey streamgage 10310500; Clear Creek near Carson City, Nevada), and $(C)$ site 3 (U.S. Geological Survey site 10310518; Clear Creek at Fuji Park at Carson City, Nevada), Clear Creek, western Nevada, water years 2004-07, 2010-12, and 2013-16. 
Site 1 (U.S. Geological Survey reference site 10310485;

\section{Clear Creek above Highway 50, near Spooner Summit, Nevada)}

A. Site 1, Cations

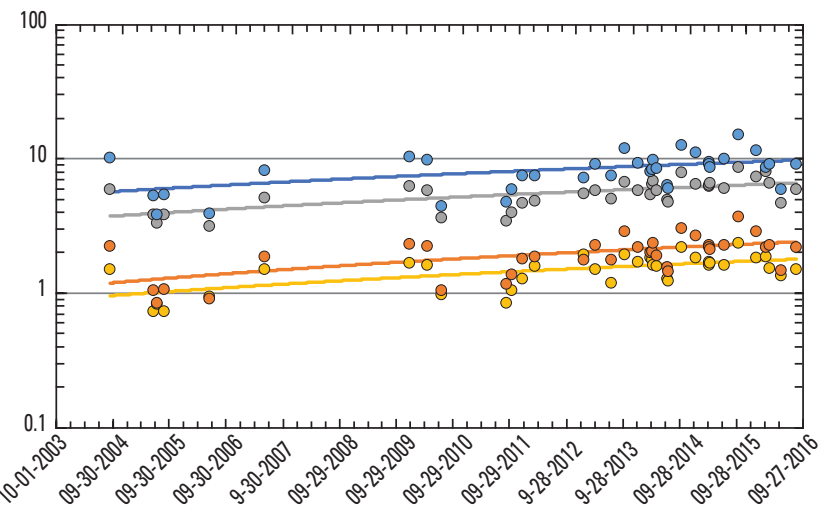

B. Site 1, Anions

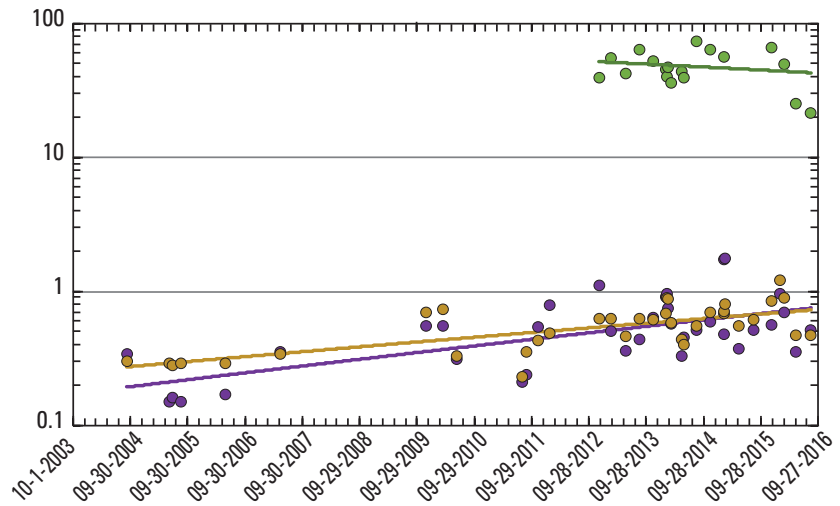

Site 2 (U.S. Geological Survey streamgage 10310500;

Clear Creek near Carson City, Nevada)

C. Site 2, Cations

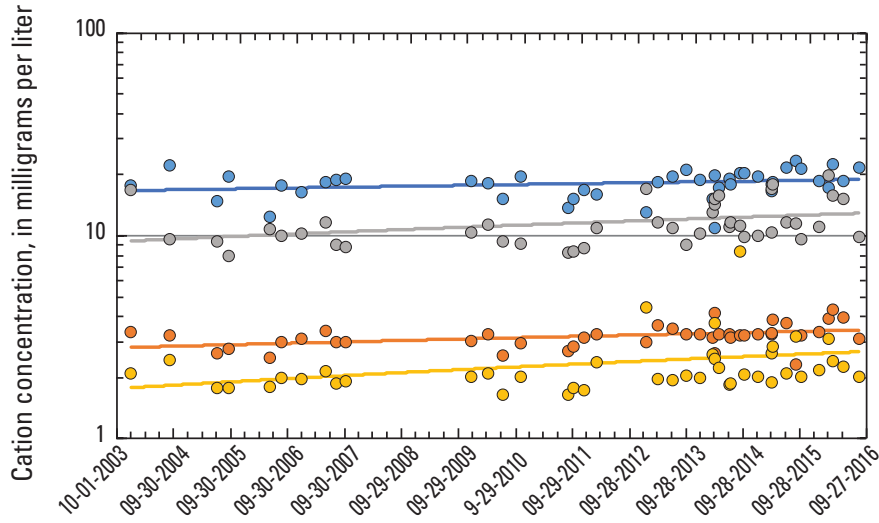

D. Site 2, Anions

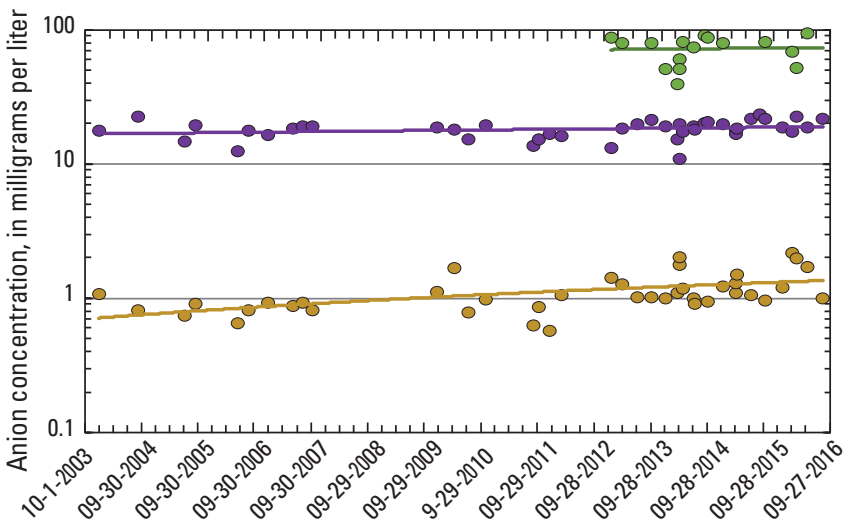

Site 3 (U.S. Geological Survey site 10310518;

Clear Creek at Fuji Park, at Carson City, Nevada)

E. Site 3, Cations

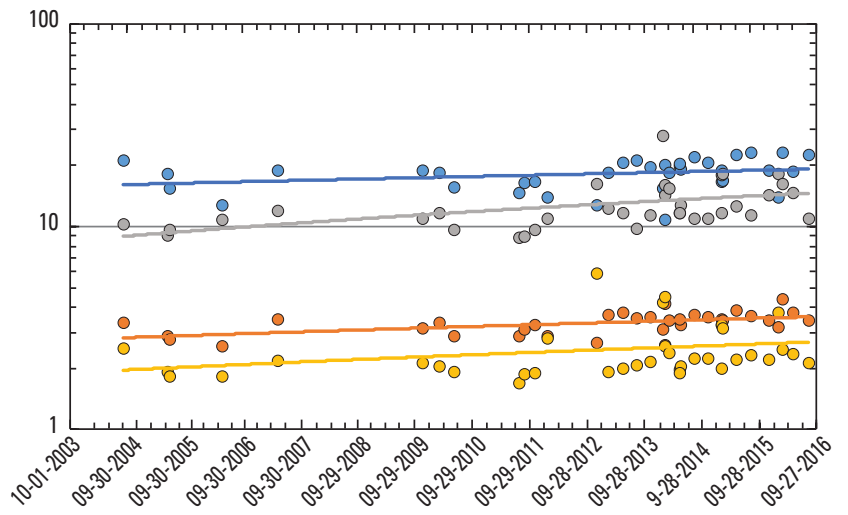

F. Site 3 , Anions

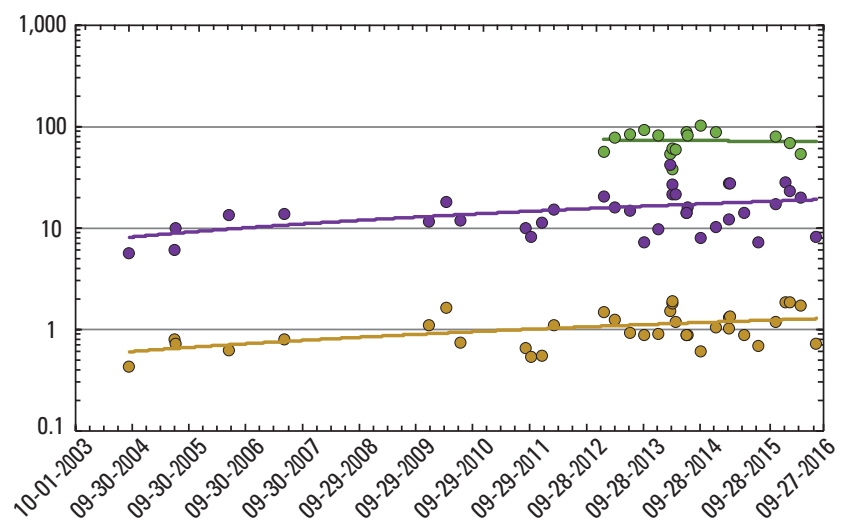

EXPLANATION

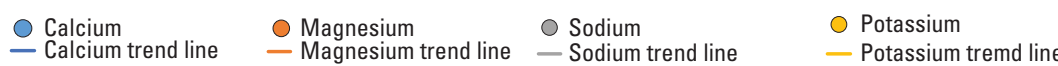

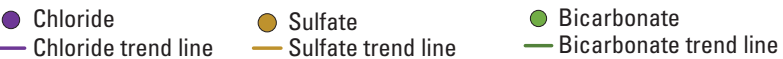

Figure 22. Major ion concentrations at Clear Creek sampling sites, western Nevada for period of record, $2004-07$ and 2010-16. $(A)$ site 1 cations, $(B)$ site 1 anions, $(C)$ site 2 cations, $(D)$ site 2 anions, $(E)$ site 3 cations, and $(F)$ site 3 anions. 
A. Site 1 (U.S. Geological Survey reference site10310485; Clear Creek above Highway 50, near Spooner Summit, Nevada)
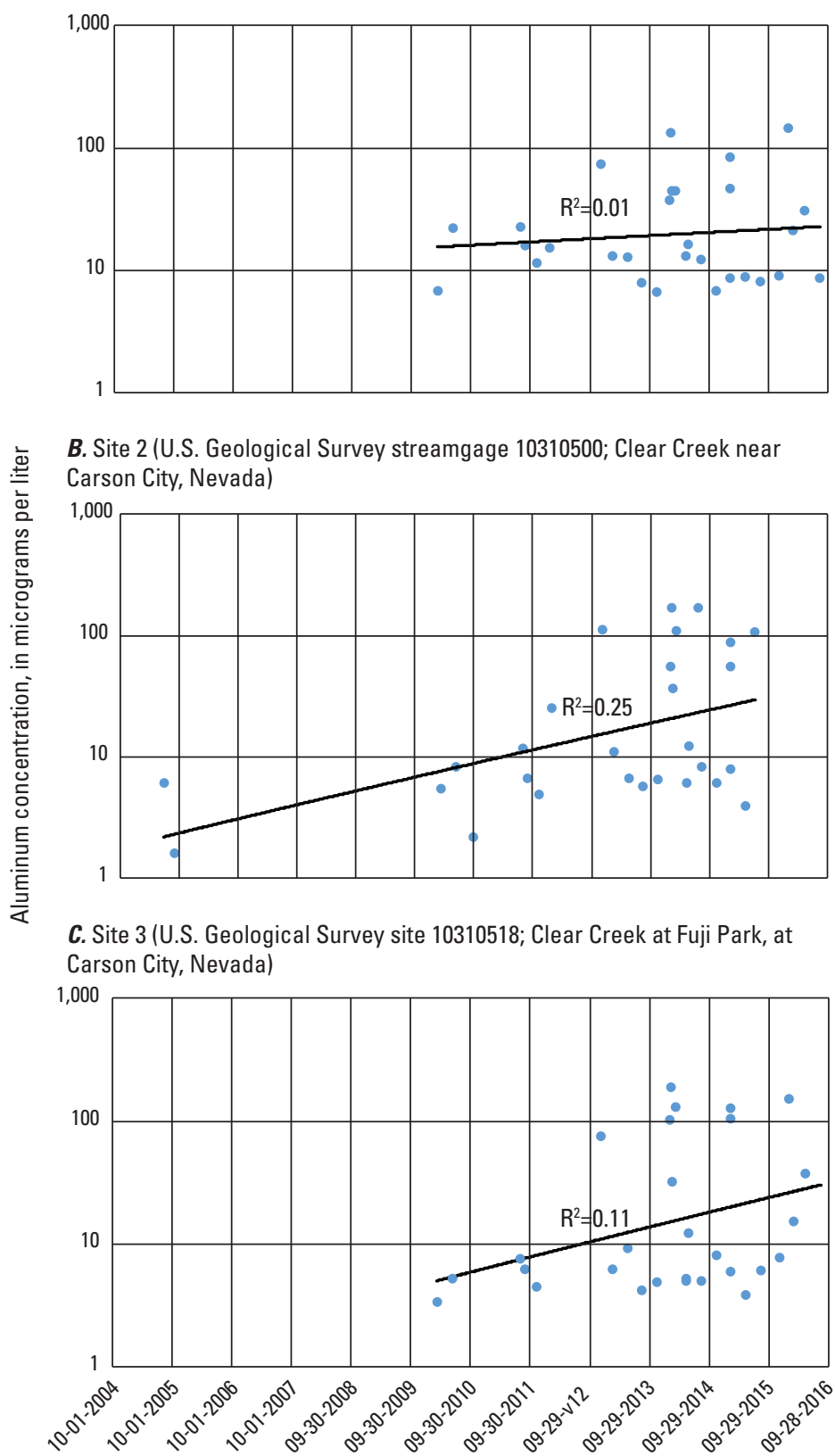

Figure 23. Dissolved aluminum concentrations in Clear Creek, western Nevada at $(A)$ site $1,(B)$ site 2, and $(C)$ site 3. 
Table 10. Frequency of selected polycyclic aromatic hydrocarbon (PAH) compound measurements in semi- permeable membrane device extracts. These PAHs have been associated with used motor oil (Cotton and others, 1977; National Research Council, 1983; Irwin and others, 1997).

[These PAHs have been associated with used motor oil (Cotton and others, 1977; National Research Council, 1983; Irwin and others, 1997). QL: The quantification level was provided by the USGS National Water Quality Laboratory. A limit of quantification is defined as 10 standard deviation units above the average analytical blank response (Childress and others, 1999). Frequency of detection: A PAH compound was considered detected when the laboratory provided a measurement above the quantification level for the composited sample, not normalized for the number of membranes included in the composite. Each SPMD membrane extract for a given sample was composited into an ampoule by Environmental Sampling Technologies after dialysis but prior to analysis by the USGS National Water Quality Laboratory. Blank ampoules were a composite of two SPMD membranes; environmental ampoules were a composite of six membranes (Keith, 1991). Abbreviations: DF, detection frequency; QL, quantification level; SPMD, semipermeable membrane device; PAH, polynuclear aromatic hydrocarbon; ng, nanogram]

\begin{tabular}{|c|c|c|c|c|c|c|c|c|}
\hline \multirow[b]{2}{*}{ Compound } & \multirow[b]{2}{*}{$\begin{array}{c}\mathrm{OL} \\
\text { (ng/ampoule) }\end{array}$} & \multirow[b]{2}{*}{$\begin{array}{c}\text { Analytical } \\
\text { recovery } \\
\text { (percent) }\end{array}$} & \multicolumn{6}{|c|}{ Frequency of detection (number/total) and range in concentration (ng/ampoule) } \\
\hline & & & $\begin{array}{c}\text { Dialysis } \\
\text { blank } \\
\text { (DF) }\end{array}$ & $\begin{array}{l}\text { Dialysis blank } \\
\text { concentration }\end{array}$ & $\begin{array}{c}\text { Field } \\
\text { blank } \\
\text { (DF) }\end{array}$ & $\begin{array}{l}\text { Field blank } \\
\text { concentration }\end{array}$ & $\begin{array}{l}\text { Environmental } \\
\text { (DF) }\end{array}$ & $\begin{array}{l}\text { Environmental } \\
\text { concentration }\end{array}$ \\
\hline Fluoranthene & 100 & $78-102$ & $1 / 5$ & $<\mathrm{QL}-434$ & $1 / 6$ & $<\mathrm{QL}-344$ & $1 / 6$ & $<\mathrm{QL}-921$ \\
\hline 1-methylphenanthrene & 100 & $83-100$ & $1 / 5$ & $<\mathrm{QL}-137$ & $1 / 6$ & $<\mathrm{QL}-105$ & $1 / 6$ & $<\mathrm{QL}-375$ \\
\hline Naphthalene & 100 & $67-92$ & $2 / 5$ & $<\mathrm{QL}-667$ & $4 / 6$ & $<\mathrm{QL}-556$ & $4 / 6$ & $<\mathrm{QL}-2,200$ \\
\hline
\end{tabular}

\section{Fire Chemistry}

Wildland fires are a part of many desert environments and can alter the precipitation runoff characteristics of a discharge area for extended periods of time (Parise and Cannon, 2012). Since 1984, three significant fires have occurred in the lower Clear Creek drainage basin (fig. 2). The most recent fire was lightning-ignited on July 16, 2014, burned approximately 250-300 acres (roughly 2 percent of the drainage basin), and was fully contained by July 19, 2014 (figs. 2 and 25). On July 21, 2014, 1 day after the fire was extinguished, an isolated thunderstorm occurred in the Clear Creek drainage basin. Storm runoff from the burned area triggered the autosampler at site 2 and brought increased concentrations of ash-laden sediment into Clear Creek (fig. 26). A total of six bottles were sent in for sediment analysis, representing different points of the 2-peak storm hydrograph, and one bottle was sent in for limited water-quality analysis (fig. 26). The runoff from the storm resulted in an initial surge of suspended sediment $(6,390 \mathrm{mg} / \mathrm{L})$, representative of the first flush off the burn area, which was nearly 100 times greater than the 2014 annual median $(65 \mathrm{mg} / \mathrm{L})$. Overall, the concentration of suspended sediment during the July 21, 2014 storm averaged 1,866 mg/L, and the storm sample median was significantly greater than the median of all other samples collected in 2014 (fig. 27). Nearly a year later, in early July 2015, another summer storm event passed through the Clear Creek drainage basin and a second round of ash-laden autosampler samples were collected.
The median suspended-sediment concentration was again significantly greater than all other 2015 samples (fig. 27).

Other studies have documented changes in water chemistry that are typical after a wildland fire. Earl and Blinn (2003) indicated elevated concentrations of ammonium, nitrate, phosphate, potassium, and alkalinity. On July 2, 2002 the Gondola Fire burned 28 percent of the Eagle Rock Creek drainage basin in the Lake Tahoe Basin. Evaluation of water chemistry in Eagle Rock Creek following the fire showed elevated concentrations of ammonium, nitrate, and phosphorous (Allander, 2006). Within 4 years of the Gondola Fire, reactive phosphorus concentrations had almost returned to pre-fire concentrations; nitrate concentrations continued to show higher seasonal variations than pre-fire conditions. The single post-fire water quality sample collected on July 21, 2014 and submitted to the USGS NWQL for limited water chemistry analyses showed noticeable increases in manganese and potassium; there were no effects on aluminum or iron concentrations (fig. 28). Post-fire ammonia plus organic nitrogen concentration in Clear Creek was $17 \mathrm{mg} / \mathrm{L}$; nearly 47 times greater than the 2014 pre-fire median of seven samples $(0.365 \mathrm{mg} / \mathrm{L}$; table 9$)$. When samples were collected again, 1 month after the fire (August 2014), ammonia plus organic nitrogen concentrations had returned to those associated with pre-fire conditions. Concentrations of ammonia plus organic nitrogen from the 2015, 1-yearpost fire sample, showed similar spikes, but overall lower concentrations than immediately after the fire in 2014. 

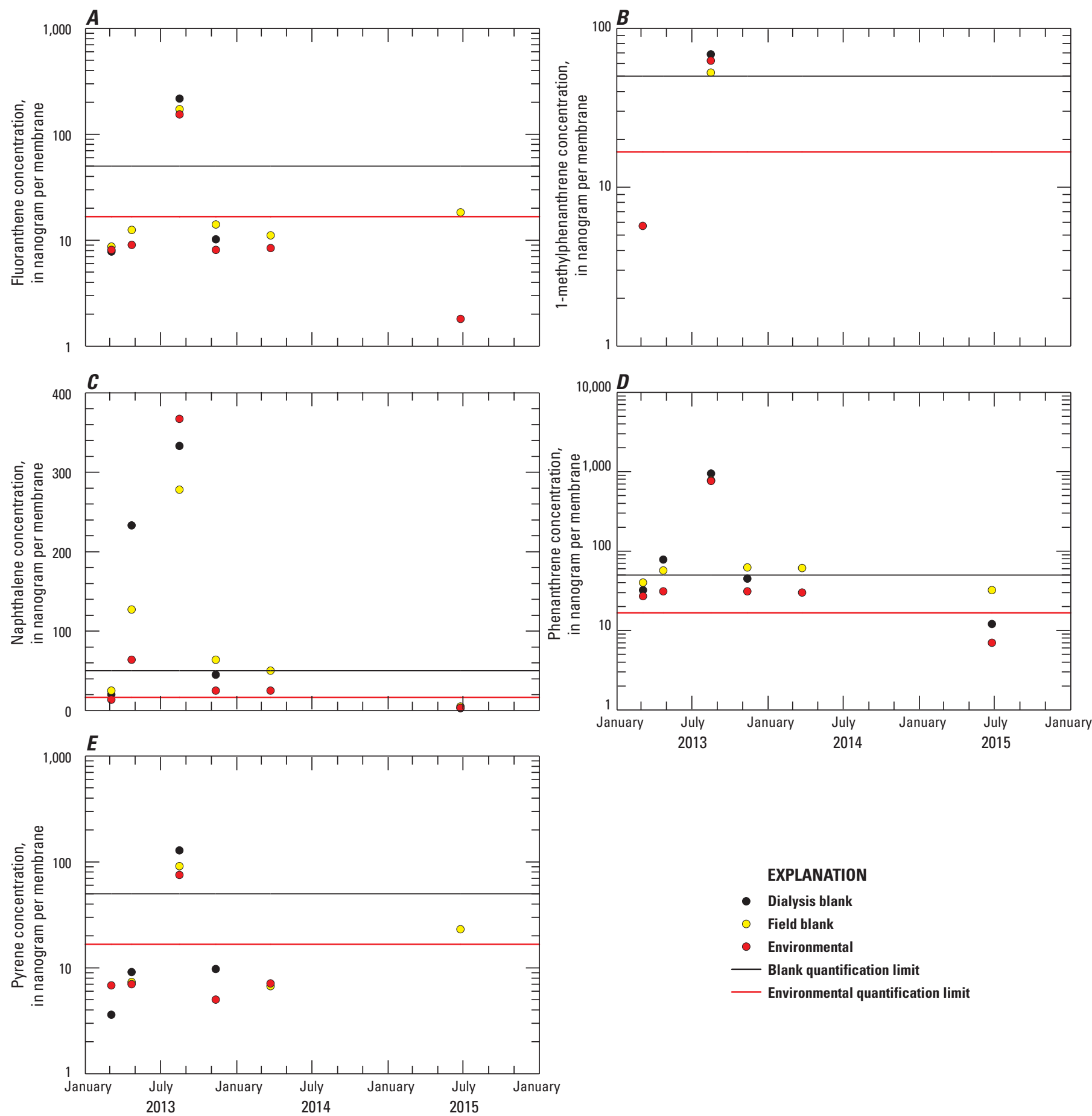

EXPLANATION

- Dialysis blank

- Field blank

- Environmental

- Blank quantification limit

— Environmental quantification limit

Figure 24. Normalized $(A)$ fluoranthrene, $(B)$ 1-methylphenanthrene, $(C)$ naphthalene, $(D)$ phenanthrene, and $(E)$ pyrene concentrations in dialysis blanks, field blanks, and environmental samples from Clear Creek, Nevada. Samples not specifically shown in figure had polycyclic aromatic hydrocarbon concentrations less than the quantifiable level of $100 \mathrm{ng} / \mathrm{ampoule}$, and the U.S. Geological Survey National Water Quality Laboratory (NWQL) did not provide an estimated concentration less than this limit. Data associated with the dialysis blank for March 24, 2014, was lost due to an instrument malfunction at the NWQL. 

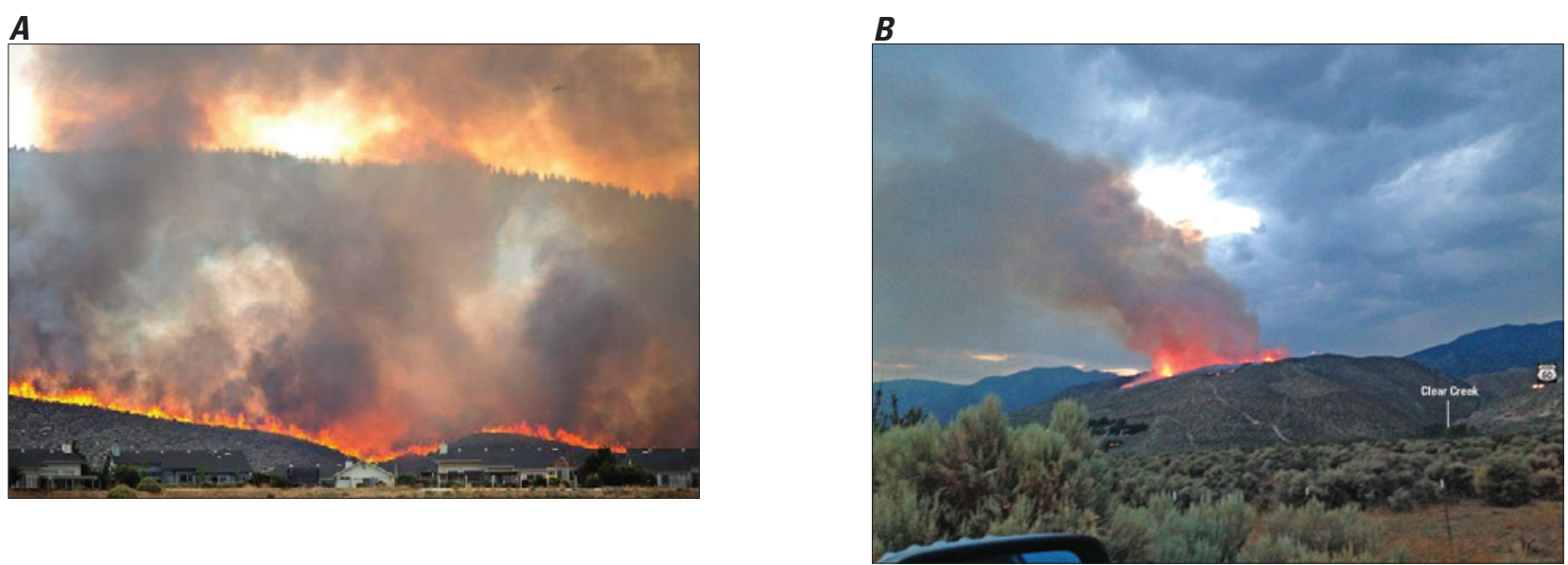

Figure 25. Clear Creek fire, western Nevada, July 16-19, 2014. (A) Photograph looking northwest from the Topsy Lane shopping center just south of Carson City, July 16, 2014. Photograph by Kippy S. Spilker, the Nevada Appeal (used with permission). (B) Photograph looking southwest from Highway 50 near southern end of Carson City, July 18, 2014. Photograph by U.S. Geological Survey.
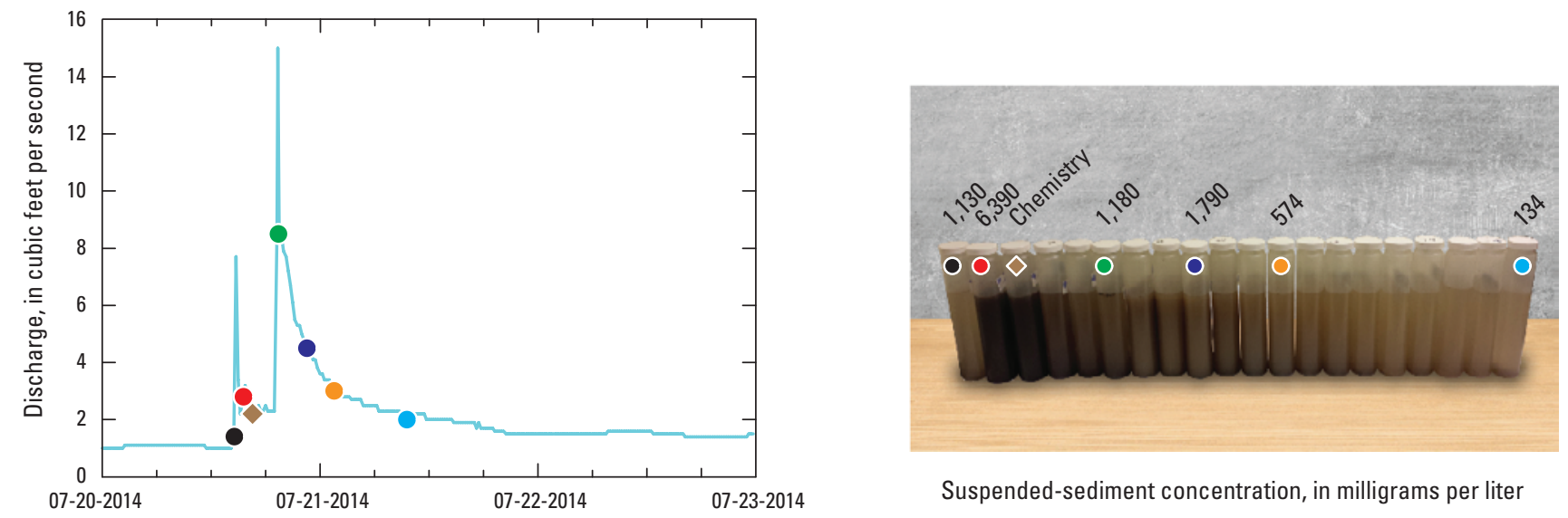

Suspended-sediment concentration, in milligrams per liter

Figure 26. Hydrograph of summer thunderstorm, immediately following Clear Creek fire and corresponding autosampler suspendedsediment sample collection, site 2 (U.S. Geological Survey streamgage 10310500; Clear Creek near Carson City, Nevada), Clear Creek, western Nevada, July 20-21, 2014. 


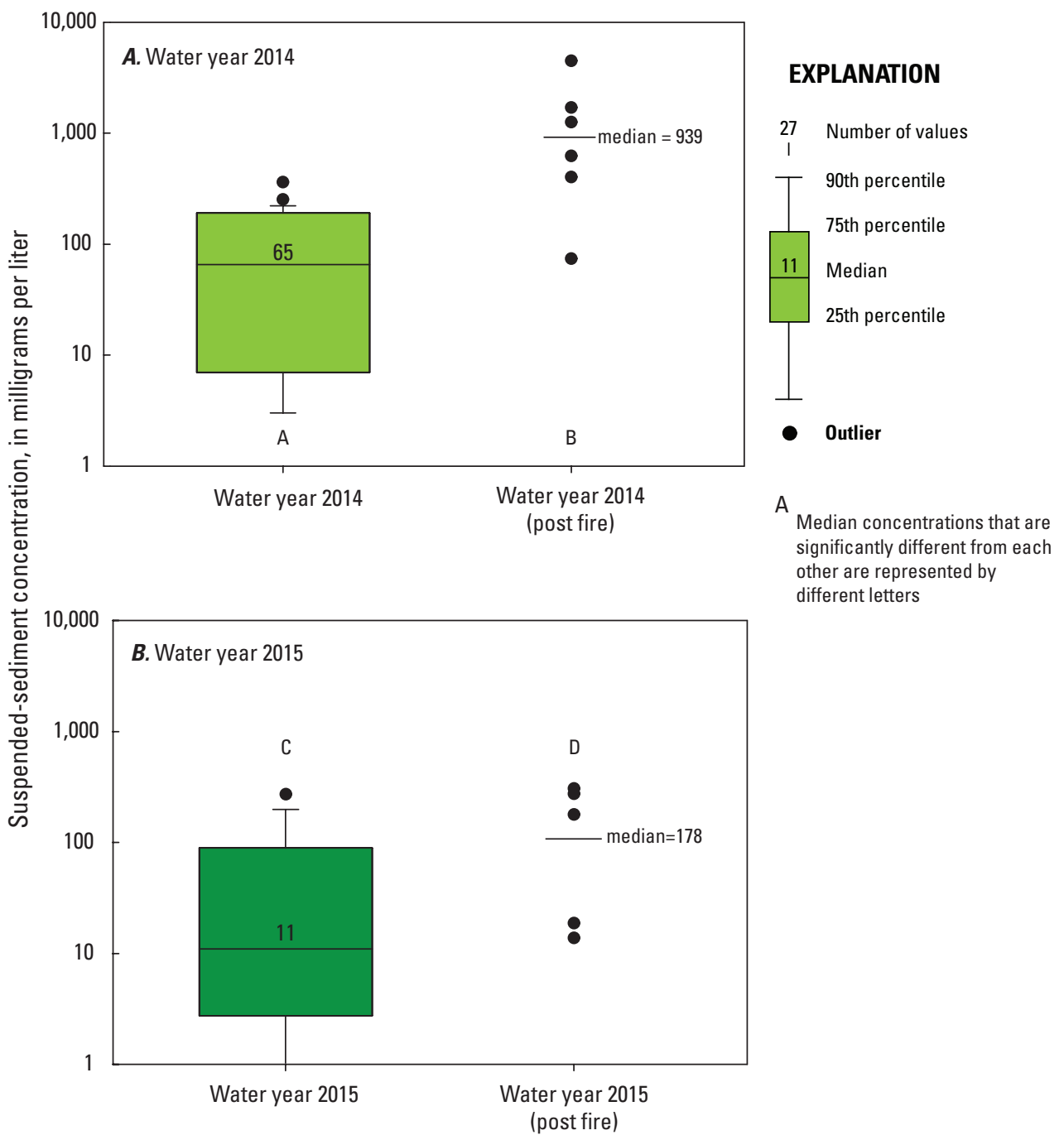

Figure 27. Relation between all suspended-sediment concentration samples collected in water year 2014-15 and the post-fire samples, site 2 (U.S. Geological Survey streamgage 10310500; Clear Creek near Carson City, Nevada), Clear Creek, western Nevada. 


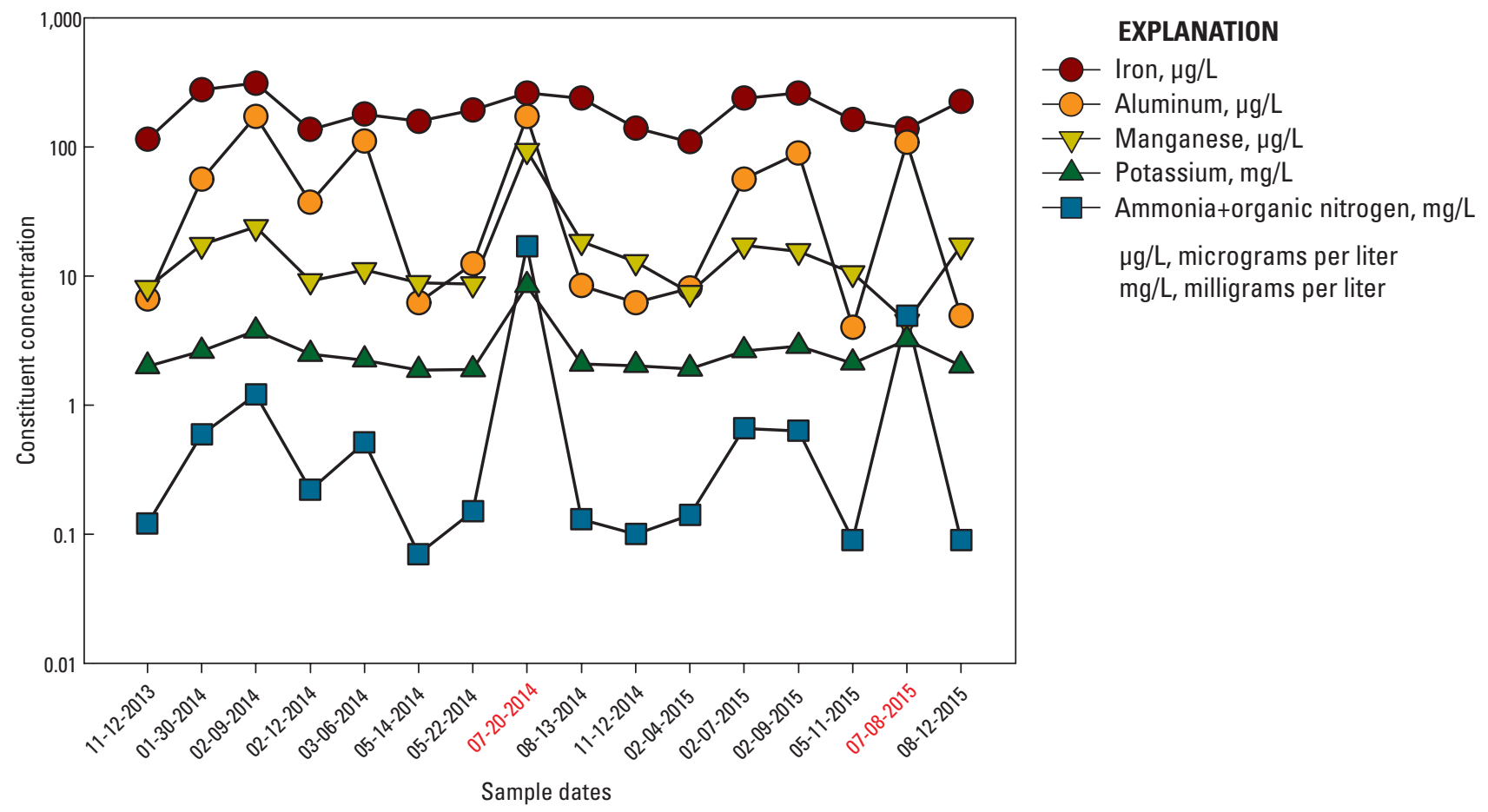

Figure 28. Selected water chemistry at site 2 (U.S. Geological Survey streamgage 10310500; Clear Creek near Carson City, Nevada), Clear Creek, western Nevada, 2014-15.

Crouch and others (2006) noted that the application of fire retardants had minimal effect on local surface-water quality. The chemical composition of fire retardant used in the Clear Creek drainage basin consisted mostly of ( $>85$ percent by weight) an ammonium polyphosphate solution (salt), attapulgus clay ( $<5$ percent by weight, bentonite or kaolinite, each high in aluminum), iron oxide (for the red color, $<5$ percent by weight), and some trade secret performance additives ( $<8$ percent by weight) (Stead Air Attack Base,
Bureau of Land Management Carson City District, written commun., October 2, 2015). It is unclear whether or not the initial peak in ammonia plus organic nitrogen and aluminum was the result of fire suppression efforts; however, given that there were no observable peaks in iron and that concentrations of ammonium and phosphorus and aluminum returned to prefire conditions within a month following the fire, it is unlikely that fire retardants used for fire suppression influenced stream chemistry for any appreciable period of time. 


\section{Summary and Conclusions}

Clear Creek is a small alpine stream that drains the eastern Sierra Nevada near Lake Tahoe, flows roughly parallel to the Highway 50 corridor, and ultimately discharges to the Carson River near Carson City, Nevada. It is unclear how historical and ongoing development in the drainage basin are influencing the physical and chemical characteristics of Clear Creek. In 2004, the Nevada Department of Transportation was issued a permit by the Nevada Division of Environmental Protection in response to pollutant discharge to the municipal stormwater sewer system. In turn, the Nevada Department of Transportation developed a Clear Creek Storm Water Management Program and entered into a cooperative agreement with the U.S. Geological Survey to assess general water quality of Clear Creek and sediment loading to the Carson River from the drainage basin. Data collected as part of a baseline study from WYs 2004-07 and an interim study from WYs 2010-12 included discharge, selected water-quality parameters, and suspended-sediment concentrations from three Clear Creek sampling sites. Each sampling site represents different land use characteristics within the drainage basin. Site 1 is not streamgaged and represents the headwater area of the upper drainage basin and is therefore considered a reference site; site 2 is streamgaged and represents the middle drainage basin area, which includes some lowdensity residential areas; and site 3 is not streamgaged and represents the lower drainage basin area, which includes more urbanization. Data were used to determine general water chemistry characteristics and sediment loads and yields. This study builds on the findings of the 2004-07 and 2010-12 studies and serves as a continuation of the data collection and analyses of Clear Creek discharge dynamics and associated water-quality and sediment concentrations and loads during WYs 2013-16.

Clear Creek discharge varies with different snowpack conditions and seasonal climate in the drainage basin. Generally, discharges in the creek are highest during the spring (March-May) during spring snowmelt; however, rain-on-snow events can cause considerable increases in discharge during winter and early spring months. Discharge has been collected continuously at site 2 during WYs 1949-62 and 1990-2016. The long-term annual mean discharge is $5.05 \mathrm{ft}^{3} / \mathrm{s}$, whereas during this study (WYs 2013-16), the annual mean discharge was $2.61 \mathrm{ft}^{3} / \mathrm{s}$. Generally, because of low precipitation conditions during 2013-15, mean monthly discharge was less than median mean-monthly discharges over the period of record (1962-2012). WYs 2014 and 2015 exhibited particularly low precipitation in the drainage basin, resulting in mean monthly discharges generally very near or less than the 10th percentile of discharge for full WY record. Overall, the flows in Clear Creek during this period of study were much lower than during the 2004-07 and 2010-12 studies and contributed to many of the overall apparent trends in sediment and chemical characteristics.
Suspended-sediment samples collected at the three Clear Creek sites during periods of base flow, storm events, and the snowmelt-runoff period were analyzed for sediment load (suspended-sediment concentration and bedload), and sand-fine break. Samples were also collected periodically for nutrient, major ion, and trace element chemistry. Median suspended-sediment concentrations at each of the three Clear Creek sampling sites were lower than the previous datasets, although only at site 2 and 3 were statistically lower. Because Clear Creek discharge was lower during this study than the previous investigation periods, it was undetermined if sediment reduction is actually occurring or just a result of lower flows. The installation of the autosampler at site 2 in 2014 has made sediment sample collection possible over a wider range of field conditions and during times of day not feasible for field staff to visit the site. The majority of these autosampler samples were collected during storm events; therefore, discharges and associated suspended-sediment concentrations were generally greater than discretely collected samples.

For samples collected during this study, suspendedsediment loads ranged from less than 0.01 to 0.28 ton/d at site $1,0.02$ to 42.8 ton/d at site 2 (including autosampler data), and 0.01 to 11 ton/d at site 3 . There was not a significant difference between loads at sites 2 and 3 for the period of record; however, with continued sampling during the current study, suspended-sediment loads at site 3 are significantly lower than at site 2 , which suggests sediment deposition between sites 2 and 3 where the creek bed gradient greatly flattens along the alluvial fan. The single highest instantaneous suspended-sediment load (42.8 ton/d) was observed at site 2 during a precipitation event that occurred in early February 2014 when discharge reached $44 \mathrm{ft}^{3} / \mathrm{s}$. An analysis of the relation between suspended-sediment loads and discharge between the 2004-07, 2010-12, and 2013-16 datasets indicated no significant difference between suspended-sediment/discharge relations at sites 1 and 2 between the study periods, but a significant relation change of lower loads at site 3 since 2012.

During both previous studies (WYs 2004-07 and 2010-12), suspended-sediment loads associated with high discharge at all three sites were statistically greater than loads associated with low discharge. Continued data collection has increased the sample size enough that the loads associated with low, moderate, and high discharge categories have become statistically different, meaning loads associated with the moderate discharge zone were statistically greater than loads associated with low discharge zone, and so on.

Bedload is highly variable and dependent on the creek reaching a threshold discharge sufficient to dislodge the material from the streambed. That threshold discharge is different for each of the three sites. No bedload was observed or measured at site 1 during the current study. Bedload was only measured at discharges greater than or equal to $3.3 \mathrm{ft}^{3} / \mathrm{s}$ at 
site 2 (as compared to $2.8 \mathrm{ft}^{3} / \mathrm{s}$ during the interim study), and $45 \mathrm{ft}^{3} / \mathrm{s}$ at site 3 during the current study and was comprised of mostly sand-sized sediment with little gravel. A comparison of samples both collected on February 9, 2014, at sites 2 and 3 indicates deposition of nearly 6 ton/d, or 92 percent of the bedload material between the two sites. For a given discharge at site 2, there was less bedload sediment during 2010-12 than during 2004-07. Although bedload for a given discharge during the 2010-12 interim study was lower than the baseline 2004-07 study, the four bedload samples added to the dataset during the current study supported a similar relation to the 2010-12 interim study. However, these comparisons made using limited data and there is insufficient data collected from similar discharges to perform a proper analysis. Because NDOT erosion mitigation work has been ongoing during this study, continued data collection is suggested to help strength the relation between bedload and discharge for use in future analysis, particularly during high flow. Total sediment loads, which is the combined suspended-sediment load and bedload, are a function of stream discharge and, therefore, can vary substantially by year. Annual sediment loads were computed for site 2 using daily discharge and relation between suspended-sediment load and bedload and ranged from 870 to 5,300 tons during 2004-07, from 320 to 1,770 tons during 2010-12, and from 50 to 200 tons during 2013-16. Although the ranges in annual loads during each study period were not statistically different from one study period to the next, total loads were statistically higher in the 2004-07 study than they are currently. Total sediment yield at site 2 ranged from 56 to 344 (ton $\left./ \mathrm{mi}^{2}\right) / \mathrm{yr}$ during 2004-07, from 21 to $115\left(\right.$ ton $\left./ \mathrm{mi}^{2}\right) / \mathrm{yr}$ during $2010-12$, and from 3 to $13\left(\mathrm{ton} / \mathrm{mi}^{2}\right) / \mathrm{yr}$ during 2013-16. Again, the lower yield observed during this study is mainly a result of lower discharge.

Clear Creek water samples were collected and analyzed for selected major inorganic ions, trace metals, and nutrients during this study. Water-quality samples were typically collected at each site on the same day in order to provide a snapshot of Clear Creek water quality with distance downstream. Analysis of water chemistry samples indicated that Clear Creek continues to be a dilute calcium bicarbonate type water with low nutrient concentrations. Generally, cations are dominated by calcium during the fall season and shift to sodium during winter and spring, while the anions are dominated by bicarbonate in the fall season and shift to chloride during the winter and springs seasons. Concentrations of major ions at all three sites generally increased in time throughout the study periods mainly as a result of lower discharge.

During this study, the general water chemistry characteristics measured in Clear Creek (water temperature, $\mathrm{pH}$, and specific conductance) were similar to those observed during previous study periods. Specific conductance values were consistently lowest at site 1 , reflecting its headwater location, while no significant difference was measured in specific conductance values between sites 2 and 3 . When specific conductance measurements from each of the datasets
(2004-07, 2010-12, and 2013-16) were compared, it was found that although there was no significant change from the 2004-07 to 2010-12 study, there was a significant increase in specific conductance in the current dataset at all three sites. This is mainly a result of lower discharge during this study.

Semipermeable membrane devices (SPMDs) were deployed seasonally during calendar year 2013 to better characterize the possible contribution of storm-water runoff from the highway and road in proximity to Clear Creek. SPMDs were analyzed for concentrations of polycyclic aromatic hydrocarbons compounds associated with used motor oil and it was found that it is likely that detected concentrations were mainly a result of contamination and not used motor oil from Clear Creek.

A lightning-ignited fire burned roughly 2 percent of the Clear Creek drainage basin in July 2014. A rain event 1 day after the fire was extinguished washed increased concentrations of ash-laden sediment into Clear Creek that were nearly 140 times greater than that of the WY 2014 suspended-sediment concentration mean. Although concentrations of select nutrients and other dissolved metals were elevated immediately following the fire, concentrations returned to within normal ranges within 1-months' time.

\section{References Cited}

Allander, K.K., 2006, Update on the effect of a large wildfire on stream-nutrient concentrations within an undisturbed watershed in the Lake Tahoe Basin [poster]: Science as a Tool in Lake Tahoe Basin Management, Incline Village, Nevada, October 18-20, 2006, Poster Presentation.

Alvarez, D.A., 2010, Guidelines for the use of the semipermeable membrane device (SPMD) and the polar organic chemical integrative sampler (POCIS) in environmental monitoring studies: U.S. Geological Survey, Techniques and Methods 1-D4, 28 p. [Available at https:// pubs.usgs.gov/tm/tm1d4/.]

Brown and Caldwell and Walker \& Associates, 2009, Reclaimed water use analysis, Carson River watershed: Consultant report prepared for Carson Water Subconservancy District. (Also available at http://www.cwsd.org/wp-content/ uploads/2014/07/2009-6-30WaterReuseReport_Walker1. pdf.)

Bureau of Land Management, 2017, BLM NV Wildland Fire Perimeters: Bureau of Land Management, Final Perimeter Polygons, accessed January 24, 2018 at https://navigator. blm.gov.

Cardinalli, J.L., Roach, L.M., Rush, F.E., and Vasey, B.J., 1968, State of Nevada hydrographic areas, scale 1:500,000, in Rush, F.E., Index of hydrographic areas in Nevada: Nevada Division of Water Resources Information Report 56, 38 p. 
Childress, C.J.O., Foreman, W.T., Connor, B.F., and Maloney, T.J., 1999, New reporting procedures based on long-term method detection levels and some considerations for interpretations of water-quality data provided by the U.S. Geological Survey National Water Quality Laboratory: U.S. Geological Survey Open-File Report 99-193, 19 p. [Available at https://water.usgs.gov/owq/OFR_99-193/index. html.]

Cohen, J., Cohen, P., West, S.G., and Aiken, L.S., 2003, Applied multiple regression/correlation analysis for the behavioral sciences (3rd ed.): Mahwah, New Jersey, Lawrence Earlbaum Associates, 736 p.

Cotton, F.O., Whisman, M.L., Goetzinger, J.W., and Reynolds, J.W., 1977, Analysis of 30 used motor oils: Hydrocarbon Processing, v. 56, no. 9, p. 131-140.

Crouch, R.L., Timmenga, H.J., Barber, T.R., and Fuchsman, P.C., 2006, Post-fire surface water qualityComparison of fire retardant versus wildfire-related effects: Chemosphere, v. 62, no. 6, p. 874-889.

Cvengroš, J., Liptaj, T., and Pronayová, N., 2015, Polyaromatic hydrocarbons in used motor oils: Petroleum and Coal, v. 57, no. 4, p. 315-237.

Davis, B.E., and Federal Interagency Sedimentation Project, 2005, A guide to the proper selection and use of federally approved sediment and water-quality samplers: U.S. Geological Survey Open-File Report 2005-1087, 20 p. [Available at http://pubs.usgs.gov/of/2005/1087/.]

Dodge, F.C.W., Papike, J.J., and Mays, R.E., 1968, Hornblendes from granitic rocks of the Central Sierra Nevada Batholith, California: Journal of Petrology, v. 9, no. 3, p. 378-410. [Available at https://academic.oup.com/ petrology/article-abstract/9/3/378/1417210.]

Dominguez-Rosado, E., and Pichtel, J., 2003, Chemical characterization of fresh, used and weathered motor oil via GC/MS, NMR and FTIR techniques: Proceedings of the Indiana Academy of Sciences, v. 112, no. 2, p. 109-116.

Earl, S.R., and Blinn, D.W., 2003, Effects of wildfire ash on water chemistry and biota in southwestern U.S.A. streams: Freshwater Biology, v. 48, no. 6, p. 1015-1030. [Available at https://doi.org/10.1046/j.1365-2427.2003.01066.x.]

Edwards, T.K., and Glysson, G.D., 1999, Field methods for measurement of the fluvial sediment: U.S. Geological Techniques of Water-Resource Investigation, book 3, chap. C2, 89 p. [Available at https://water.usgs.gov/owq/ FieldManual/Chapter7-Archive/chapter7.2/twri.html.]

Federal Interagency Sediment Project, 2013, Sampling with the US BL-84 bedload sampler: Federal Interagency Sediment Project. [Available at http://water.usgs.gov/fisp/docs/ Instructions_US_BL-84_990507.pdf.]
Fisher, J.B., 1978, Flume development for a study of bedload and suspended sediment in Clear Creek Drainage, Eastern Sierra Nevada: University of Nevada, Reno, Masters thesis, $83 \mathrm{p}$.

Geospatial Multi-Agency Coordination, 2013, U.S. historic fire data: Geospatial Multi-Agency Coordination, accessed January 28, 2018, at https://rmgsc.cr.usgs.gov/ outgoing/Geomac/historic_fire_data/.

Glancy, P.A., and Katzer, T.L., 1976, Water-resources appraisal of the Carson River Basin, western Nevada: Nevada Department of Conservation and Natural Resources, Water Resources-Reconnaissance Series Report 59, 126 p.

Forman, R.T.T., 2003, Road ecology—Science and solutions: Washington, D.C., Island Press, 424 p.

Helley, E.J., and Smith, Winchell, 1971, Development and calibration of a pressure-difference bedload sampler: U.S. Geological Survey Open-File Report 73-108, 38 p. [Available at https://pubs.er.usgs.gov/publication/ofr73108.]

Helsel, D.R., and Hirsch, R.M., 2002, Statistical methods in water resources: U.S. Geological Survey Techniques of Water-Resources Investigations report 04-A3, 523 p. [Available at https://pubs.usgs.gov/twri/twri4a3/.]

Hem, J.D., 1985, Study and interpretation of the chemical characteristics of natural water: U.S. Geological Survey Water Supply Paper 2254 (3rd ed.). [Available at https:// pubs.er.usgs.gov/publication/wsp2254.]

Homer, C.G., Dewitz, J.A., Yang, L., Jin, S., Danielson, P., Xian, G., Coulston, J., Herold, N.D., Wickham, J.D., and Megown, K., 2015, Completion of the 2011 National Land Cover Database for the conterminous United StatesRepresenting a decade of land cover change information: Photogrammetric Engineering and Remote Sensing, v. 81, no. 5, p. 345-354.

Horowitz, A.J., Demas, C.R., Fitzgerald, K.K., Miller, T.L., and Rickert, D.A., 1994, U.S. Geological Survey protocol for the collection and processing of surface-water samples for the subsequent determination of inorganic constituents in filtered water: U.S. Geological Survey Open-File Report 94-539, 57 p. [Available at https://pubs.er.usgs.gov/publication/ ofr94539.]

Huckins, J.N., Petty, J.D., Orazio, C.E., Lebo, J.A., Clark, R.C., Gibson, V.L., Gala, W.R., and Echols, K.R., 1999, Determination of uptake kinetics (sampling rates) by lipid-containing semipermeable membrane devices (SPMDs) for polycyclic aromatic hydrocarbons (PAHs) in water: Environmental Science \& Technology, v. 33, no. 21, p. 3918-3923. [Available at https://doi.org/10.1021/ es $990440 u$. 
Huntington, J.M., and Savard, C.S., 2015, Discharge, suspended sediment, bedload, and water quality in Clear Creek, western Nevada, water years 2010-12: U.S. Geological Survey Scientific Investigations Report 2015-5124, 39 p. [Available at http://dx.doi.org/10.3133/ sir20155124.]

Irwin, R.J., Van Mouwerik, M., Stevens, L., Seese, M.D., Basham, W., 1997, Environmental Contaminants Encyclopedia - C2-Naphthalene Entry: National Park Service, https://www.nature.nps.gov/hazardssafety/toxic/ nap_c2.pdf.

Keith, L.H., 1991, Environmental sampling and analysis-A practical guide: New York, Lewis Publishers, 160 p.

Lopes, T.J., and Dionne, S.G., 1998, A review of semivolatile and volatile organic compounds in highway runoff and urban stormwater: U.S. Geological Survey Open-File Report 98-409, 73 p. [Also available at https://pubs.usgs.gov/ of/1998/ofr98-409/.]

Lu, S.-T., and Kaplan, I.R., and the Shan-Tan, 2008, Characterization of motor lubricating oils and their oil-water partition: Environmental Forensics, v. 9, no. 4, p. 295-309, https://doi.org/10.1080/15275920802119441.

National Research Council, 1983, Polycyclic aromatic hydrocarbons-Evaluation of sources and effects: Washington, D.C., National Academy Press, accessed March 15, 2017, at url, https://books.google.com/ books?id=tVArAAAAYAAJ\&lpg=SA2-PA3\&dq=1methylphenanthrene $\% 20$ used $\% 20$ motor $\% 20$ oil\&pg $=\mathrm{SA} 2-$ PA3\# $\mathrm{v}=$ onepage \& $\mathrm{q}=1$-methylphenanthrene $\% 20$ used $\% 20$ motor\%20oil\&f=false.

Nevada Division of Environmental Protection, 2012b, Standards for water quality, Administrative Code 445A.1836: Nevada Division of Environmental Protection, accessed August 27, 2012, at http://www.leg.state.nv.us/nac/nac-445a. html\#NAC445ASec1836.

Nevada Division of Environmental Protection, 2012c, Standards for water quality, Administrative Code 445A.1836: Nevada Division of Environmental Protection, Carson Region, accessed August 27, 2012, at http://www.leg.state. nv.us/nac/nac-445a.html\#NAC445ASec1838.

Olsen, M.C., Iverson, J.L., Furlong, E.T., and Schroeder, M.P., 2004, Methods of analysis by the U.S. Geological Survey National Water Quality Laboratory-Determination of polycyclic aromatic hydrocarbon compounds in sediment by gas chromatography/mass spectrometry: U.S. Geological Survey Water-Resources Investigations Report 03-4318, 45 p. [Available at https://nwql.usgs.gov/WRIR-03-4318.shtml.]
Parise, M., and Cannon, S.H., 2012, Wildfire impacts on the processes that generate debris flows in burned watersheds: Natural Hazards, v. 61, no. 1, p. 217-227. [Available at https://doi.org/10.1007/s11069-011-9769-9.]

PBS\&J International, Inc., 2003, Clear Creek erosion assessment: Final Report prepared for Nevada Department of Transportation, $48 \mathrm{p}$.

Porterfield, G., 1972, Computation of fluvial sediment discharge: U.S. Geological Survey Techniques of WaterResources Investigations, chap. C3, book 3, 66 p. [Available at https://pubs.usgs.gov/twri/twri3-c3/.]

Rush, F.E., 1968, Index of hydrographic areas in Nevada: Nevada Division of Water Resources, Information Report 6, $38 \mathrm{p}$.

Rantz, S.E., 1982a, Measurement and computation of streamflow_-Volume 1, measurement of stage and discharge: U.S. Geological Survey Water-Supply Paper 2175, 284 p. [Available at http://pubs.usgs.gov/wsp/wsp2175/.]

Rantz, S.E., 1982b, Measurement and computation of streamflow-Volume 2, computation of discharge: U.S. Geological Survey Water-Supply Paper 2175, 631 p. [Available at http://pubs.usgs.gov/wsp/wsp2175/.]

Rush, F.E., 1968, Index of hydrographic areas in Nevada: Nevada Division of Water Resources, Information Report 6, $38 \mathrm{p}$.

Seiler, R.L., and Wood, J.L., 2009, Sediment loads and yield, and selected water-quality parameters in Clear Creek, Carson City, and Douglas County, Nevada, Water Years 2004-07: U.S. Geological Survey Scientific Investigations Report 2009-5005, 44 p. [Available at https://pubs.usgs.gov/ $\operatorname{sir} / 2009 / 5005 /$.

Shakoane, L.N., 2015, Characterization and quanitification of polycyclic aromatic hydrocarbons (PAHs) in used and fresh engine oil by chromatography and spectroscopy techniques: Johannesburg, South Africa, University of the Witwatersrand, Engineering and the Built Environment, Masters thesis, $61 \mathrm{p}$.

Smith, J.A., Witkowski, P.J., and Fusillo, T.W., 1988, Manmade organic compounds in the surface water of the United States-A review of current understanding: U.S. Geological Survey Circular 1007, 92 p. [Available at https://pubs.usgs. gov/circ/c1050/index.htm.]

Stevenson, T.K., 1989, Clear Creek erosion-sedimentation evaluation-Carson-Walker Resource Conservation and Development Area: U.S. Department of Agriculture, 7 p. 
Uhrich, M.A., and Bragg, H.M., 2003, Monitoring instream turbidity to estimate continuous suspended-sediment loads and yields and clay-water volumes in the upper North Santiam River Basin, Oregon, 1998-2000: U.S. Geological Survey Water-Resources Investigation Report 2003-4098, 44 p. [Available at http://pubs.usgs.gov/wri/WRI03-4098/.]

U.S. Geological Survey, various dates, National field manual for the collection of water-quality data: U.S. Geological Survey Techniques of Water-Resources Investigations, Book 9, chap. A6, 237 p. [Available at http://water.usgs.gov/ owq/FieldManual/Chapter6/Ch6_contents.html.]

U.S. Geological Survey, 2013, Water-resources data for the United States, Water Year 2013: U.S. Geological Survey Water-Data Report WDR-US-2013, site 10310500, accessed October 7, 2015, at http://wdr.water.usgs.gov/wy2013/ pdfs/10310500.2013.pdf?1440543626964.

U.S. Geological Survey, 2018, National Water Information System: U.S. Geological Survey, accessed August 11, 2017, at http://waterdata.usgs.gov/nwis/inventory/?site no $=10310500 \&$ agency_cd=USGS\&am.

U.S. Geological Survey, 2016, U.S. Geological Survey National Hydrography Dataset (NHD) downloadable data collection-National Geospatial Data Asset (NGDA) National Hydrography Dataset (NHD): U.S. Geological Survey National Geospatial Technical Operations Center. [Available at http://nhd.usgs.gov.]
Wenzel, K.D., Vrana, B., Hubert, A., and Schüürmann, G., 2004, Dialysis of persistent organic pollutants and polycyclic aromatic hydrocarbons from semipermeable membranes-A procedure using an accelerated solvent extraction device: Analytical Chemistry, v. 76, no. 18, p. 5503-5509. [Available at https://doi.org/10.1021/ac0494073.]

Wilde, F.D., ed., variously dated, Field measurements: U.S. Geological Survey Techniques of Water-Resources Investigations, book 9, chap. A6, with sec. 6.0-6.8, accessed November 10, 2015, at http://pubs.water.usgs.gov/twri9A6/

Wilde, F.D., Sandstrom, M.W., and Skrobialowski, S.C., 2014, Selection of equipment for water sampling (ver. 3.1): U.S. Geological Survey Techniques of Water-Resources Investigations, book 9, chap. A2, accessed November 10, 2015, at http://pubs.water.usgs.gov/twri9A2/.

U.S. Geological Survey, 2006, National field manual for the collection of water-quality data: U.S. Geological Survey Techniques of Water-Resources Investigations, book 9, chap. A4, 231 p. [Available at http://water.usgs.gov/owq/ FieldManual/chapter4/pdf/Chap4_v2.pdf.]

U.S. Geological Survey, 2018, Water quality samples for Nevada: U.S. Geological Survey, web. [Available at https:// nwis.waterdata.usgs.gov/nv/nwis/qwdata.] 

Publishing support provided by the U.S. Geological Survey

Science Publishing Network, Tacoma Publishing Service Center

For more information concerning the research in this report, contact the Director, Nevada Water Science Center

U.S. Geological Survey

2730 N. Deer Run Rd.

Carson City, Nevada 89701

https://nevada.usgs.gov 
